Florida International University FIU Digital Commons

3-30-2012

\title{
Rise of Public Works and Sanitation in San Juan, Puerto Rico, 1765-1823
}

Monica Lynn Crowe

Florida International University, mpott002@fiu.edu

DOI: $10.25148 /$ etd.FI12050129

Follow this and additional works at: https://digitalcommons.fiu.edu/etd

\section{Recommended Citation}

Crowe, Monica Lynn, "Rise of Public Works and Sanitation in San Juan, Puerto Rico, 1765-1823" (2012). FIU Electronic Theses and Dissertations. 592.

https://digitalcommons.fiu.edu/etd/592

This work is brought to you for free and open access by the University Graduate School at FIU Digital Commons. It has been accepted for inclusion in FIU Electronic Theses and Dissertations by an authorized administrator of FIU Digital Commons. For more information, please contact dcc@fiu.edu. 
FLORIDA INTERNATIONAL UNIVERSITY

Miami, Florida

RISE OF PUBLIC WORKS AND SANITATION

IN SAN JUAN, PUERTO RICO, 1765-1823

A thesis submitted in partial fulfillment of the

Requirements for the degree of
MASTERS OF ARTS
in
HISTORY
by

Monica Lynn Crowe 
To: Dean Kenneth Furton

College of Arts and Sciences

This thesis, written by Monica Lynn Crowe, and entitled Rise of Public Works and Sanitation in San Juan, Puerto Rico, 1765-1823, having been approved in respect to style and intellectual content, is referred to you for judgment.

We have read this thesis and recommend that it be approved.

$\begin{array}{r}\text { M. Sherry Johnson } \\ \hline \text { Astrid Arrarás } \\ \hline \text { Noble David Cook, Major Professor }\end{array}$

Date of Defense: March 30, 2012

The thesis of Monica Lynn Crowe is approved.

$\begin{array}{r}\text { Dean Kenneth G. Furton } \\ \text { College of Arts and Sciences } \\ \hline \begin{array}{r}\text { Dean Lakshmi N. Reddi } \\ \text { University Graduate School }\end{array}\end{array}$

Florida International University, 2012 
(C) Copyright 2012 by Monica Lynn Crowe

All right reserved. 


\section{DEDICATION}

I dedicate this thesis to my loving mother and to my handsome husband. Mutti, you edited and assisted me from 1,200 miles away, giving me strength during the low times. You always picked up the phone when the stress became too much. To Steven, for without your support, patience, and belief, I would have never achieved this goal. You have always been my solid base, and I will be in your debt as long as I live. 


\section{ACKNOWLEDGMENTS}

I wish to thank my committee members for their support, dedication, patience, and tolerance throughout this process. Dr. Astrid Arrarás always greeted me with a smile and embrace that demonstrated her caring heart and wise knowledge of Puerto Rico and research. Dr. M. Sherry Johnson opened up her own research and connections to find sources. I enjoyed her research stories as much as I enjoyed the rich information her sources provided my study. Leonardo "Leo" Falcon demonstrated true patience and skill while editing my thesis. I wish you luck and happiness in your future as a doctorial student. Most of all, Dr. Noble David Cook saw hope and promise within me since our first meeting, giving me the tools and confidence to achieve in graduate school. Although my writings skills were challenging to my committee, their willingness to work through revisions and editing meant the world to me.

There are no words to describe the value and appreciation I have for my professors and the Florida International University's History Department. As I venture out and begin my career, I am always complimented on my work ethic, research abilities, and confidence. I proudly state, "I am a graduate of the History Department." I thank you all. 


\author{
ABSTRACT OF THE THESIS \\ RISE OF PUBLIC WORKS AND SANITATION \\ IN SAN JUAN, PUERTO RICO, 1765-1823
}

by

Monica Lynn Crowe

Florida International University, 2012

Miami, Florida

\title{
Professor Noble David Cook, Major Professor
}

The purpose of this thesis is to evaluate and understand the growth of public works as part of urban development in San Juan, Puerto Rico, between 1765 and 1823. In San Juan, attaining basic provisions was complicated by distinctive circumstances such as the increasing population, administrative decisions, and financial limitations. This thesis draws from demography, medicine, urban studies, and primary documents to understand how the changes in San Juan's established political, economic, demographic, and environmental systems allowed for the growth of public works to support the city's population. With the introduction of economic and military Bourbon Reforms, the existing colonial system fractured, collapsing in the first decade of the nineteenth century from financial burdens, internal infrastructure decay, and the abdication of the Spanish king. Imperial loyalty and intra-monarchial attention to the general public altered Puerto Rico's imperial role, establishing a new system that allowed public work and sanitation to thrive. 


\section{TABLE OF CONTENTS}

CHAPTER

PAGE

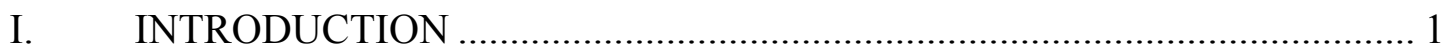

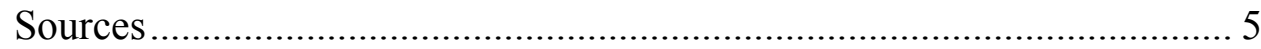

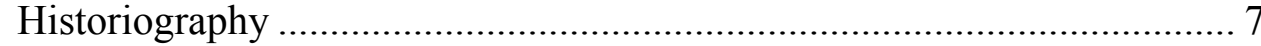

Puerto Rican and San Juan Historiography ................................... 8

Public Health Historiography ....................................................... 21

The Evolving Fields of Crisis Management and Environmental

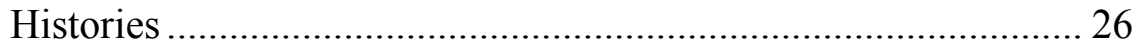

Historiographical Contributions.................................................. 29

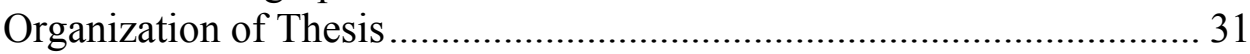

II. CHAPTER 1: GEOGRAPHY AND EARLY HISTORY OF SAN JUAN, PUERTO RICO, 1493-1765: THE FORMATION OF AN ISOLATED,

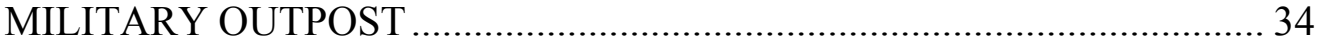

Puerto Rico's Adaptable Geography ………………………………..... 34

San Juan, Puerto Rico's Early History and the Development of a

Dependent Military Outpost ...................................................................... 37

San Juan's Structure and Status, 1604-1765 ........................................... 44

III. CHAPTER 2: PUERTO RICO'S BOURBON REFORMS AND PROPOSED

ECONOMIC POTENTIAL, 1765-1797 ..................................................... 49

Spain's Bourbon Reforms and their American Application...................... 49

Field Marshal Alejandro O'Reilly Bourbon Analysis of Puerto Rico ...... 51

Outcomes of the Bourbon Reforms in Puerto Rico ................................... 54

IV. CHAPTER 3: ECOLOGICAL PROBLEMS AND THE SEARCH FOR

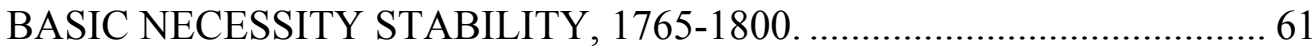

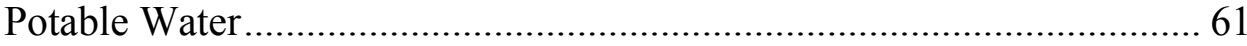

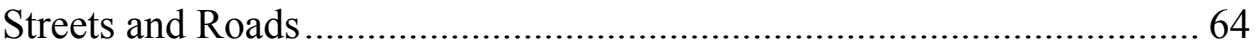

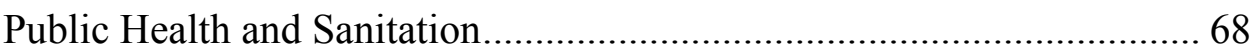

Eighteenth-Century Natural Disasters and San Juan's Responses ............ 69

Short and Long-Term Hurricane Effects ................................................. 70

Disease: Ecological Results and Impacts................................................ 75

V. CHAPTER 4: THE DECLINE OF SAN JUAN'S POTABLE WATER, PUBLIC HEALTH, AND INFRASTRUCTURE TO 1808 ……………….... 79

San Juan's Growing Crises, 1800-1808 ................................................. 80

Smallpox and Economic Instability: the Rise of Public Health, 1801-1804

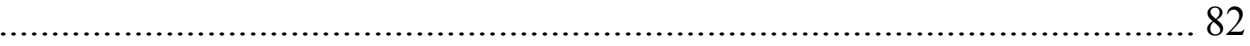

Decaying Infrastructure and Changing Political Agendas, 1804-1808 .... 90 
VI. CHAPTER 5: CHALLENGING CONDITIONS DURING SAN JUAN'S CONSTITUTIONAL ADMINISTRATION ………………………............. 97

Spanish Loyalty and Opposition to French Control, 1808-1812 …........... 97

Political Changes within Spain and its Empire......................................... 97

Economic and Infrastructure Stagnation............................................... 101

The Constitution of 1812 and Public Works Progression, 1812-1814 ... 107

VII. CHAPTER 6: PUERTO RICO AND THE RETURN OF MONARCHIAL RULE TO 1823 ........................................................................... 114

Economic Growth and New Political Advantages under King Ferdinand

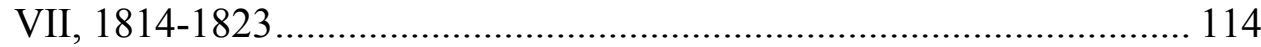

Public Work Continuations and Repetitive Shortfalls ........................... 122

VIII. EPILOGUE: PUBLIC HEALTH TRANSFORMATION AND NEW OBSTACLES IN MID-NINETEENTH CENTURY SAN JUAN

The Development of Puerto Rico's Conservative Colonial Government and the Rise of the Plantation Economy.... 129

Building the Modern San Juan: Further Need to Understand Public

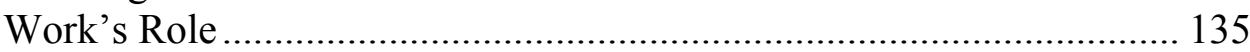

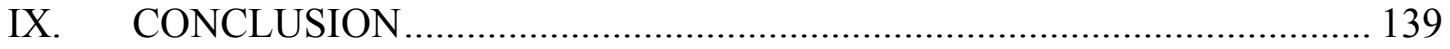

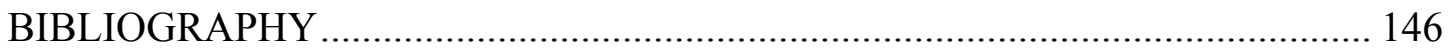

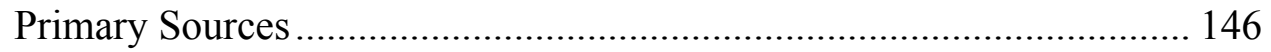

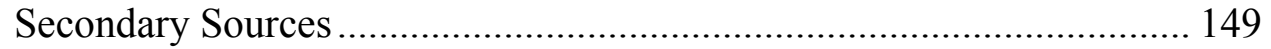

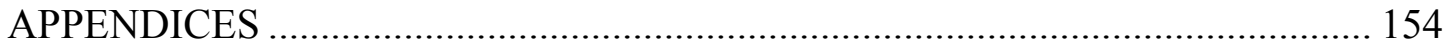




\section{TABLE OF FIGURES}

TITLE PAGE

I. Part of “A Plan of the Island of Porto Rico,” Library of Congress, 1760s......35

II. Part of "Plano de Puerto Rico" by Tomás López de Vargas Machuca, Library

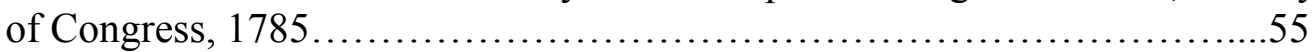

III. Part of "Geometrical Plan of the Principal Harbour in the Island of Porto Rico” by Cosme Damián de Churruca y Elorza, Library of Congress,

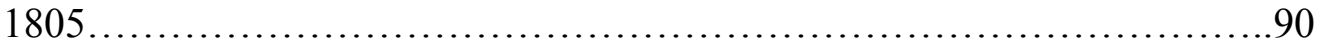

IV. Table 1: Total Population of Puerto Rico by Select Census Years, 1530-

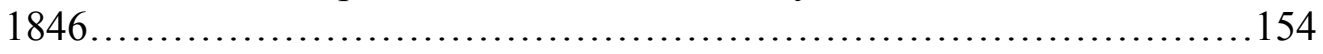

V. Table 2: Total Population of San Juan, Puerto Rico, by Select Census Year,

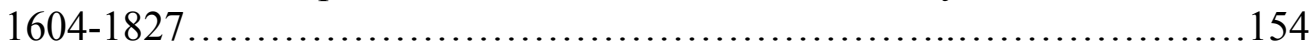

VI. Table 3: Situado Shipments to Puerto Rico by Year, 1764-1812...........155 


\section{INTRODUCTION}

As the capital of Puerto Rico, San Juan received multiple visitors throughout its Spanish colonial history. Both Hispanic and non-Hispanic travelers gave their impressions of the island through San Juan's condition and spread their observations through their journal publications. The general impression during the late seventeenth and eighteenth centuries illustrated a decaying, but sustainable capital that had been forgotten by the Spanish Government. Famous visiting priest, Agustin Iñigo Abbad y Lasiera, complained in his 1776 published report about the colonists' lack of land use for cultivation, desiring a sedentary life focusing on dancing and mutual unions. ${ }^{1}$ Little ornamentation covered the city houses, while the location of the Hospital del Rey was a threat for the capital's healthy wellbeing. ${ }^{2}$ French Botanist Andre Pierre Ledru's 1797 journey to Puerto Rico did state San Juan contained a fresh breeze, but the constant humidity, swamps, and other ecological disturbances created harmful vapors. ${ }^{3}$ Diseases, like tetanus, affected week-old newborns and over a third of the population suffered from scabies. $^{4}$

\footnotetext{
${ }^{1}$ Agustin Iñigo Abbad y Lasiera, Historia geográfica civil y natural de la isla de San Juan Bautista de Puerto Rico (Río Piedras: Editorial Universitaria Universidad de Puerto Rico, 1979), 185.

${ }^{2}$ Ibid, 102, 185.

${ }^{3}$ André Pierre Ledru, Viaje a la isla de Puerto Rico en el año 1797, ejecutado por una comisión de sabios franceses, de orden de su gobierno bajo la dirección del Capitán Nicolás Baudín (Río Piedras: Ediciones del Instituto de Literatura Puertorriqueña, 1957), 57, 124.

${ }^{4}$ Ibid, 125.
} 
However, in less than fifty years, San Juan developed into a modern, prosperous city with an advancing infrastructure for the support of a booming economy and conservative politics. While conducting an island study for Queen Isabella II in 1834, George D. Flinter lauded San Juan as “...one of the best and certainly the healthiest town in the West Indies." ${ }^{5}$ He continued by describing how a woman with thin shoes walking the capital's streets, following a rain, will not get wet and will have little worry of filth lining the roads. The public paid for the new theatre's expensive painting and ornamentation, costing at least 200,000 dollars. $^{6}$ Other accounts, such as an anonymous leaf published in The Dial in 1843, commented on the city's orange aroma and lacking wheeled carriages. ${ }^{7}$ Peace and quiet was unlikely because of children singing and guitars playing during African parties. ${ }^{8}$ How in such a short period of time did the capital's infrastructure and sanitation change from semi-sustainable and harmful to livingly and embellished?

The purpose of this thesis is to evaluate and understand the growth of public works as part of urban development in San Juan, Puerto Rico, between 1765 and 1823. Public works usually responded to crises that affected the basic necessary provisions; be it water, travel or health issues. In San Juan, attaining basic provisions was complicated by distinctive circumstances such as the increasing population, administrative decisions,

${ }^{5}$ George D. Flinter, An Account of the Present State of the Island of Puerto Rico (London: Longman, Rees, Orme, Brown, Green, and Longman, 1834), 39.

${ }^{6}$ Ibid, 39.

7 “A Leaf from 'A Voyage to Porto Rico'," in The Dial: A Magazine for Literature, Philosophy, and Religion (Boston: E. P. Peabody, 1843), 522.

${ }^{8}$ Ibid, 524. 
and financial limitations. The thesis draws from demography, medicine, urban studies, and primary documents to understand how the changes in San Juan's established political, economic, demographic, and environmental systems allowed for the growth of public works to support the city's population. It follows administrative decisions, both at the local and imperial levels, to determine solutions to the lack of basic provisions through public works.

Public works typically refer to the infrastructure built to supplement needed provisions for human survival, especially in highly populated areas. People require food, water, hygiene, and shelter to survive healthily. In the case of San Juan, located on an inlet, it did not contain adequate fresh water sources because of the surrounding saltwater bay. Fresh water sources were aggravated by the population growth and ecological changes. Foodstuffs were imported from other parts of the island because the small landmass made agriculture unlikely. ${ }^{9}$ Furthermore, the inlet also limited transportation, particularly important as the city became a major military outpost following the sixteenth century. Its tropical location, lack of sanitation, and environmental influxes introduced contagious pathogens. Despite these limitations, San Juan's population was sustained by existing public works built following the island's colonization.

For public works development, four specific factors are usually needed. The political administration at both the local and imperial levels must be conscious of the need for development. The economy must be able to support the new infrastructure since it absorbs large amounts of funds through labor salaries, materials, and other

\footnotetext{
${ }^{9}$ David Martin Stark. “'There is No City Here, but a Desert': The Contours of City Life in 1673 San Juan." Journal of Caribbean History 42, no. 2 (2008): 257.
} 
contributions. There must be a specific need, noticed by the political and social institutions. In an urban area, the population growth demands an increase in public works requirements as more people consume natural sources and produce unhealthy conditions. Lastly, the environment, especially tropical regions, may interrupt typical conditions through natural disasters, such as hurricanes, droughts, and epidemics. Public works alleviate ecologic episodes by continue providing for urban inhabitants.

San Juan's public works growth began as the consequence of changes in these four factors. For public works to be possible in the capital, the existing established system had to end and a new supportive system had to develop that would promote public works. The established system references the political, demographic, and economic structure of the island and its capital. Between 1765 and 1823 San Juan experienced new changes in its political, economic, and demographic formation that broke the centuriesold system and allowed for the development of a new system beneficial for public improvements. The environment furthered these changes, especially as ecological abnormalities placed more pressure on the existing infrastructure and forced administrative responses on behalf of the city's population. Resulting from these shifts, public works and sanitation became possible in both the capital and throughout the island.

To support the argument, three specific types of public works are illustrated. Public works typically occur when basic necessities are required for human survival in a given area. People need water for survival. San Juan lacked natural water sources on the inlet, requiring the construction of certain features within the city to catch rainfall or the transportation of water from inland. Although not a basic necessity, streets and roads were essential to San Juan. The city needed roads and bridges to connect to the rest of 
the island in order to supply its residents with food, water, and other provisions. Within the capital, streets provided easy travel for the military and port goods. In correlation to water, streets acted as water converters and waste removal routes. Lastly, public health stressed the city's hygiene. Located in a humid, tropical climate, many diseases killed residents during both normal and disastrous weather conditions. San Juan's sanitation actions through filth removal and vaccination protected the city and provided basic needs to survive.

Potable water, street infrastructure, and public health were chosen as major examples because they were specifically important to municipal officials between 1765 and 1823. During this time period, there were strict actions taken by municipal councils to promote infrastructure and changes to these public works. Other major basic provisions were critical to administrators, but their outcomes occurred beyond public works. For example, foodstuff was a contributing factor in San Juan's development. Following hurricanes, many plantations were destroyed and food shortages plagued the city. However, local colonial officials handled the crisis by appealing to the Spanish Crown to allow imported provisions from non-Hispanic islands and colonies. The issue was resolved without specific alterations to the existing infrastructure. ${ }^{10}$

\section{Sources}

To understand the breakdown of the old established system that made way for a more public-works conscious one in the early nineteenth century, the most utilized

\footnotetext{
${ }^{10}$ Sherry Johnson, "El Niño, Environmental Crisis, and the Emergence of Alternative Markets in the Hispanic Caribbean, 1760s-70s," William and Mary Quarterly 62, no. 3 (July 2005).
} 
sources will be the political and administrative documentation from the local cabildo (town council) records, as well as several royal decrees. The cabildo records document the daily or weekly decisions of the local administration of San Juan. As the main authority for royal declaration, the cabildo and the governor met often and discussed local issues ranging from social disruptions to infrastructure decisions. The increase in public works is demonstrated in a step-by-step matter in the records, denoting changes in local concerns and focus. San Juan's cabildo records were transcribed and published throughout the 1960s, with the exception of some missing years because of conflict, suspended cabildo meetings, or because the records decayed through time. The published records account for cabildo members' attendance, statements presented, and officials designated to oversee projects. Royal decrees reveal the Spanish administrative control over Puerto Rico, especially over the Governor. These decrees provide information about the Crown's concerns in regards to the empire and the island. Some of these concerns revolutionized daily actions and allowed a new economic and demographic system to develop.

Other primary sources utilized to support the argument are Hispanic and nonHispanic accounts. These published diaries, travel accounts, and other documents provide internal and external observations from upper and lower class visitors to the island and its capital. Viewpoints within the empire differed from other European powers due to conflict and altered imperial practices. Puerto Rico's transformation throughout the late eighteen and early nineteenth centuries is illustrated in these writings, showing the capital's progress from a backwater military settlement to a prosperous economic engine for public works growth. 
Secondary sources provide the basic background needed to understand Puerto Rico's state at the turn of the century. These sources will provide the cultural, social, political, and economic approach highly studied in Puerto Rico's historiography. The publications allow proper attention to primary sources discussing public works and shifting perceptions for San Juan's role in the Spanish Empire.

In-depth analysis of other contributing factors, particularly social influences, was not fully possible because of the limited primary sources available. Although the local society is discussed through reported issues to government officials and religious processions, the thesis is heavily relied on government and administrative sources. Demography, politics, the economic structure, and the environment are weighed equally as information allowed, demonstrating that each played contributing influence to the decline of the established system and the rise of the new, public works-encouraging system. However, the primary sources available cause some unequal focus to political and economic pressures. Primary sources do exist in Puerto Rican and Spanish archives to provide other dimensions and views to the thesis analysis, but travel opportunities and digital access was not available at the time of research. It is highly encouraged for other historians and researchers to utilize the information provided by this thesis and explore the multiple avenues possible through public works and sanitation to contribute to Puerto Rican historiography.

\section{Historiography}

Most research on Puerto Rico during its Spanish colonial period centers on economic and social conditions, mainly in the nineteenth century when the island became 
a focal point for the Crown. Social history highlights variations in demography, but more in the context of slavery and plantation economies in the rural areas. Historiographical shifts occurred in the last twenty years, diverging from the study of the rural plantation complex, but most works still remain focused on racial struggles during the nineteenth century. At the same time, a new urban history supplemented the study of the rural plantation and gave an alternate viewpoint of the Puerto Rican population. Because of the relatively recent growth in the study of urban spaces, the inclusion of other historical methods and disciplines, such as medicine, geography, and public administration, are yet to be applied.

\section{Puerto Rican and San Juan Historiography}

Prior to the 1970s, the majority of Puerto Rican historiography resembled the works of Salvador Brau, Alejandro Tapia y Rivera, and other turn-of-the-century authors. Their publications highlighted major events and people in the island's early history, such as Christopher Columbus, Ponce de León, the gold boom during the sixteenth century, and piracy. They skipped much of the inter-colonial period to discuss their contemporary nineteenth century. ${ }^{11}$ Some twentieth century historians recognized the need to revise colonial history to include the overlooked centuries. Since then, some revisionists have

\footnotetext{
${ }^{11}$ Please see the following works for further studies completed by these authors: Salvador Brau, Historia de Puerto Rico (San Juan: Ediciones, 1971); Salvador Brau, La colonización de Puerto Rico: desde el descubrimiento de la isla hasta la reversion a la corona española de los privilegios de colón (San Juan: Instituto de Cultura Puertorriqueña, 1969); Salvador Brau, Puerto Rico y su historia: investigaciones criticas (Valencia: Imprenta de Francisco Vives Mora, 1894); D. Agustín Stahl, Los Indios Borinqueños (Ann Arbor: University Micofilms International, 1980); Alejandro Tapia y Rivera, Mis memorias o Puerto Rico como lo encontre y como lo dejo (Barcelona: Ediciones Rumbos, 1968).
} 
examined the social-economic structure in the rural plantations during the nineteenth century. ${ }^{12}$

Puerto Rican nineteenth century history formed from the establishments of the eighteenth century, particularly with the introduction of the Bourbon Reforms. Altagracia Ortiz's Eighteenth-Century Reforms in the Caribbean: Miguel de Muesas, Governor of Puerto Rico 1769-1776 was one of several books that explained Field Marshal Alejandro O'Reilly's military reforms. Governor Miguel de Muesas contributed to infrastructure, education, and other improvements. Many nineteenth centuries' developments utilized by politicians and planters started from Muesas' adjustment to the island. As Ortiz introduced, Puerto Rico was a subsistence agricultural society and sparsely populated when O'Reilly and Muesas arrived. With some investment from the Spanish Crown, immigration increased the island's ability to become profitable. ${ }^{13}$ To understand the nineteenth century expansion and growth, the eighteenth and earlier centuries must be considered.

Rising historians, such as Francisco Antonio Scarano and Fernando Picó, established new trends in the historiography outside common syntheses published in the

\footnotetext{
${ }^{12}$ Francisco Antonio Scarano, Immigración y clases sociales, 1 (Río Piedras: Ediciones Huracan, 1981); Francisco A. Scarano, Sugar and Slavery in Puerto Rico: The Plantation Economy on Ponce, 1800-1850 (Madison: University of Wisconsin Press, 1984); Fernando Picó, Libertad y servidumbre en el Puerto Rico del siglo XIX, 1 (Río Piedras: Ediciones Huracan, 1981).

${ }^{13}$ Altgracia Ortiz, Eighteenth-Century Reforms in the Caribbean: Miguel de Muesas, Governor of Puerto Rico 1769-1776 (Rutherford, Madison, Teaneck: Fairleigh Dickinson University Press, 1983).
} 
twentieth century. ${ }^{14}$ Francisco Scarano's Sugar and Slavery in Puerto Rico: the Plantation Economy of Ponce, 1800-1850 influenced the historiography because of its micro-historical perspective, the analysis of slavery, and the shift from subsistence agriculture into a plantation economy. Scarano studied the Ponce region because of the limitation of national sugar industry primary sources. ${ }^{15}$ He concluded that the region's sugar plantations contained fundamental economic and social components that contributed to the development of Puerto Rico's national identity. Scarano's research also analyzed the struggle between the Creole classes and foreign and political authorities. ${ }^{16}$ Fernando Picó utilized the micro-historical approach to understand the laborers of the Utuado region. Once landlords and slave owners, Picó analyzed their lives and labor to show shifts within the rural class structure. ${ }^{17}$ Both historians collaborated as well to write the edited work Immigración y clases sociales. The study was an example of the historiographical trends towards the rural plantation society and the labor related to coffee, sugar, and other productions during the nineteenth century.

\footnotetext{
${ }^{14}$ For some notable synthesis, please refer to: Cristina Campo Lacasa, Historia de la iglesia en Puerto Rico (1511-1802) (San Juan: Instituto de Cultura Puertorriqueña, 1977); Eugenio Fernández Méndez, Crónicas de Puerto Rico: desde la conquista hasta nuestros dias, 1493-1955 (Barcelona: Editorial Universidad de Puerto Rico, 1973); Eugenio Fernández Méndez, Historia cultura de Puerto Rico, 1493-1968 (San Juan: Ediciones "El Cemi," 1970); Eugenio Fernández Méndez, Proceso histórico de la conquista de Puerto Rico (1508-1640) (San Juan: Instituto de Cultura Puertorriqueña, 1970); Angel López Cantos, Historia de Puerto Rico, 1650-1700 (Seville: Publicaciones de la Escuela de Estudios Hispano-Americanos, Consejo Superior de Investigaciones Científicas, 1975); Bibiano Torres Ramírez, La Isla de Puerto Rico (1765-1800) (San Juan: Instituto de Cultura Puertorriqueña, 1968).

${ }^{15}$ Francisco A. Scarano, Sugar and Slavery in Puerto Rico, xxi-xxv.

${ }^{16}$ Ibid, 167-168.

${ }^{17}$ Picó, Libertad y servidumbre en el Puerto Rico del Siglo XIX.
} 
Many articles within this publication were parts of the authors' broader studies, including race, slavery, and labor. ${ }^{18}$

Other historians followed the examples set by Scarano, Picó, and other revisionist historians. Teresita Martínez-Vergne studied the modernization process and labor on a particular sugar plantation called San Vicente in the late nineteenth century. She examined the plantation's hardships for credit to gain capital for sugar industrialization. Her research also contained workers' immigration, the decline of slavery, the shift to wage labor, and the formation of new towns. ${ }^{19}$ As another micro-historical rural discussion, Luis A. Figueroa's research provided an alternative view to the historiography, using the Guayama region to demonstrate other labor productions. His work also suggested that Spanish colonialism contributed more to capitalism than previous historians had assumed. Considered the frontier, Caribbean and European settlers established plantations in Guayama that handled abolition and social constructs differently. ${ }^{20}$

Many publications address the issue of finances in Puerto Rico, especially since plantations required a specific amount of capital to begin. Adam Szászdi presented in his article the ways Puerto Rico handled loans and others forms of credit without a bank until the 1870s. Prior to the nineteenth century, capital was minimal, causing families to be

${ }^{18}$ Scarano, Immigración y clases sociales.

${ }^{19}$ Teresita Martínez-Vergne, Shaping the Discourse on Space: Charity and Its Wards in Nineteeth-Century San Juan, Puerto Rico (Austin: University of Texas Press, 1999), ixxii, 134-35.

${ }^{20}$ Luis A. Figueroa, Sugar, Slavery, and Freedom in Nineteenth-Century Puerto Rico (Chapel Hill: University of North Carolina Press, 2005), 1-14. 
unable to pay for basic needs and resorted to other means of exchange. With the growth of immigration, bills of exchanges formed credit and established checking accounts. Financial recovery and economies grew through the credit and capital trades. Szászdi’s work suggested one factor to why plantation productions were achievable. ${ }^{21}$

Stemming from rural plantation research, Puerto Rican urban history discussed the social and economic development within a densely populated area. However, some recent publications diverged from this trend to explore parts of the urbanized society that typically only form in these municipal areas. This thesis is another example of deviating themes in San Juan and Puerto Rican historiography, focusing on public health and other gaps that some publications briefly reference. ${ }^{22}$

Jay Kinsbruner's synthesis of Spanish-American cities gave general background for the urban sphere during the colonial period. It covered a broad range of topics, including administration, economic possibilities, religion, and family structure. The author presented each through several examples, such as Buenos Aires, Mexico City, Havana, and San Juan. Because it is meant to cover most Spanish cities in the Americas, it does not recognize specific qualities and circumstances that separate some cities. Its

\footnotetext{
${ }^{21}$ Adam Szásadi, "Credit-Without Banking-In Early Nineteenth-Century Puerto Rico," The Americas 19, no. 2 (October 1962): 149-71.

${ }^{22}$ Félix V. Matos Rodríguez, Women and Urban Change in San Juan, Puerto Rico, 1820-1868 (Gainesville: University Press of Florida, 1999); Martínez-Vergne, Shaping the Discourse on Space.
} 
generalization allowed for a basic familiarization of infrastructure and social development. $^{23}$

In San Juan's case, Adolfo de Hostos' Historia de San Juan, ciudad murada: ensayo del proceso de la civilización en la ciudad española de San Juan Bautistia de Puerto Rico, 1521-1898 provided a more in-depth study of San Juan's Spanish colonial history since the city's establishment. Like Kinsbruner, de Hostos highlighted the city's political and economic structure through its major events. He further discussed the history of particular buildings, for example surrounding forts, defenses, and public works such as the aqueduct. ${ }^{24}$

Part of the transition from the rural plantation complex involved location patterns and regional studies. Some trends transferred to the urban sphere by focusing on settlement and residential patterns. Jay Kinsbruner's article studied the patterns of housing ownership and living in San Juan during the early nineteenth century. He argued that many people who owned housing and buildings had some economic accomplishments, thus some form of status in society. He demonstrated that the freed African population in San Juan owned housing among the white population, but were more likely to live in the San Francisco barrio, a higher status section of the capital. His

${ }^{23}$ Jay Kinsbruner, The Colonical Spanish-American City: Urban Life in the Age of Atlantic Capitalism (Austin: University of Texas Press, 2005).

${ }^{24}$ Adolfo de Hostos, Historia de San Juan, ciudad murada: ensayo acerca del proceso de la civilización en la ciudad española de San Juan Bautista de Puerto Rico, 1521-1898 (San Juan: Instituto de Cultura Puertorriqueña, 1983), 479-82. 
research was a form of racial study that originated from the rural plantation historiographical trend. ${ }^{25}$

Other studies on San Juan, Puerto Rico, discussed particular groups of people within the city. Another Jay Kinsbruner's article compared San Juan and Caracas pulperos, an independent group of business owners that held no major social or political authority. In it, Kinsbruner studied the pulperos' class, their business, and personal relationships. Some groups in this class only associated with each other, while marital and familial connections expanded their businesses and/or secured their developments. The author noted the need for further research to understand their roles within the family, community, and the urban areas. ${ }^{26}$ Mariano Negrón Portillo and Raúl May Santana wrote a series of books, addressing slaves in Puerto Rican urban areas. They concentrated more on the slave's characters, labor, and relationships with the family and community, such as San Juan during the late nineteenth century. ${ }^{27}$

Teresita Martínez-Vergne's and Félix V. Matos Rodríguez's studies were some of the most notable shifts from the rural concentrations by analyzing San Juan. Their studies followed the racial and socio-economic themes, but also included women as an influential group in San Juan's development. Félix A. Matos Rodríguez's Women and Urban Change in San Juan, Puerto Rico, 1820-1868 included women, particularly the

${ }^{25}$ Jay Kinsbruner, "Caste and Capitalism in the Caribbean: Residential Patterns and House Ownership Among the Free People of Color of San Juan, Puerto Rico, 18231846," Hispanic American Historical Review 70, no. 3 (August 1990): 433-61.

${ }^{26}$ Jay Kinbruner, "The Pulperos of Caracas and San Juan During the First Half of the Nineteenth Century," Latin American Research Review 13, no. 1 (1978): 65-85.

${ }^{27}$ Raúl Mayo Santana and Mariano Negrón-Portillo, La esclavitud urbana en San Juan de Puerto Rico (San Juan: Ediciones Huracán, 1992). 
freed, enslaved, and lower classes, into Puerto Rican and urban historiography. He argued that different classes and castes of women had different opportunities, especially in regards to their gender and race. His presented information favored the higher classes, but he attempted to include freed working women after abolition. ${ }^{28}$ Teresita MartínezVergne complimented Matos Rodríguez's book by analyzing some of San Juan's institutions, many of which were established by women. She discussed several different institutions that related to the local administrations' reactions to social and urban needs. Some administrators utilized specific laws and adjusted them to address urban problems, such as child poverty, women's behavior, and health. ${ }^{29}$

Several studies discussed other urban centers in Puerto Rico and can be used to further understand municipalities throughout the island. Adam Szászdi presented an overview of San German's reorganization as another Puerto Rican profitable port. The areas' urban growth was possible by integrating surrounding populated areas. Several royal decrees allowed the region to grow economically. ${ }^{30}$ Astrid Cubano-Iguina's Rituals of Violence in Nineteenth-Century Puerto Rico, Individual Conflict, Gender, and the Law focused on racial and gender inequalities in the judicial district of Arecibo. Many of her primary sources included cases of duels, domestic abuse, rape, and fighting. She argued that punishment depended on the crime and the social class in question. Some harsher crimes were less severe in comparison to the penalty issued because of social control

\footnotetext{
${ }^{28}$ Matos Rodríguez, Women and Urban Change, 1-9, 36-58, 90-94, 105-12, 124-28.

${ }^{29}$ Martínez-Vergne, Shaping the Discourse on Space, 153-58.

${ }^{30}$ Adam Szászdi, "La municipalidad de San German en Puerto Rico (1798-1808)," Journal of Inter-American Studies 1, no. 4 (October 1959): 489-513.
} 
concerns. Some cases, such as rape, brought forward moral questions on gender and male control, forcing the society to focus on the issues. ${ }^{31}$

Some syntheses or short references included Puerto Rico demography in other research studies to supplement information. ${ }^{32}$ Additional overall population studies on Puerto Rico and specifically San Juan have not been fully explored. Migration continues to be a major focal point in the Puerto Rican historiography because of the importance of free and forced immigration to the island during the nineteenth century. These studies contribute to Puerto Rico's importance to a broader Atlantic perspective. ${ }^{33}$ However, further analysis and discussion of demographic research still needs elaboration to substantially illustrate the island's broader roles and significance.

Arturo Morales Carrión's Puerto Rico and the Non Hispanic Caribbean: a Study in the Decline of Spanish Exclusivism was one of the most notable publications on Puerto Rico from an Atlantic perspective. His book connected the island to other colonies and countries within the Caribbean basin. Morales Carrión argued that Puerto Rico held constant contact with other foreign powers, such as the Dutch, Danish, English, and French. These interactions involved the contraband trade and military excursions. The

${ }^{31}$ Astrid Cubano Iguina, Rituals of Violence in Nineteenth-Century Puerto Rico: Individual Conflict, Gender, and the Law (Gainesville: University Press of Florida, 2006), 6 .

${ }^{32}$ See syntheses: Campo Lacasa, Historia de la iglesia en Puerto Rico (1511-1802); Fernández Méndez, Crónicas de Puerto Rico; Fernández Méndez, Proceso histórico de la conquista de Puerto Rico (1508-1640); Fernández Méndez, Historia cultura de Puerto Rico, 1493-1968; López Cantos, Historia de Puerto Rico, 1650-1700; Torres Ramírez and Bibiano, Alejandro O'Reilly en las Indies (Seville: Escuela de Estudios HispanoAmericanos, 1969).

${ }^{33}$ Arturo Morales Carrión, Puerto Rico and the Non-Hispanic Caribbean: A Study in the Decline of Spanish Exclusivism (Río Piedras: University of Puerto Rico Press, 1952). 
Bourbon Reforms and Real Cédula de Gracias, an influential decree that encouraged immigration to Puerto Rico at the beginning of the nineteenth century, in 1815 opened the island to a more liberal economy, thus increasing its connections to other colonies and European countries. Morales Carrión presented the island's population as a possible unique identity because of its weak relationship with Spain. ${ }^{34}$

Jorge L. Chinea's article and book discussed Puerto Rico and its relationship with several empires, but through the growth of immigration during the nineteenth century. His article included the island's migration history, noting the emigration from the mainland after the late sixteenth century. ${ }^{35}$ Chinea's book elaborated on the article and analyzed the push and pulls factors that brought immigration to Puerto Rico. He attributed events in the Caribbean region, such as the Haitian Revolution and abolition movements, as part of the process. The Spanish colonial administration further persuaded immigrants through royal decrees, such as Real Cédula de Gracias in 1815. These changes brought an increase of slaves and capital to establish a profitable economy. Chinea's study placed Puerto Rico within a Caribbean and global context, strengthening the island's importance in the Spanish and other empires. ${ }^{36}$

Forced slave immigration to Puerto Rico continues to be a major trend in the Puerto Rican historiography because of economic and labor research. Arturo Morales

${ }^{34}$ Ibid, vii-viii, 143.

${ }^{35}$ Jorge L. Chinea, "Race, Colonial Exploitation and West Indian Immigration in Nineteenth-Century Puerto Rico, 1800-1850," The Americas 52, no. 4 (April 1996): 495519.

${ }^{36}$ Jorge L. Chinea, Race and Labor in the Hispanic Caribbean: The West Indian Immigrant Worker Experience in Puerto Rico, 1800-1850 (Gainesville: University Press of Florida, 2005), 1-37, 115-51. 
Carrión and Joseph Dorsey both analyzed the issue, especially during the Age of Abolition. Morales Carrión discussed slave immigration and life through situations such as disease and slave trading. The author stated that many abolitionists attacked the trading system when Spanish Caribbean colonies were one of the last to end slavery. ${ }^{37}$ Dorsey supported Morales Carrión and other historian's claims on the number of Africans traded between empires and within the Caribbean. He concluded that the abolition movement was more concerned with the human definition of race and protected the desired notions of politics and slavery. ${ }^{38}$

As an example of free immigration to Puerto Rico, Raquel Rosario Rivera conducted a specific study on the Real Cédula de Gracias in 1815 . Her book primarily gave quantitative and familial information on immigrants within the first decades after the decree was issued. The data included places of origin, numbers in families and slaves, and the amount of capital brought to Puerto Rico. It also addressed Puerto Rico in a general context, allowing for further specific historical research on ports and urban centers. $^{39}$

Demography is rarely discussed in colonial Puerto Rican historiography. Most studies combined the quantitative study with immigration during the early nineteenth century. As one of the few historians to study population specifically, David Martin

${ }^{37}$ Arturo Morales Carrión, Auge y decadencia de la trata negrera en Puerto Rico (18201860) (San Juan: Instituto de Cultura Puertorriqueña, 1978).

${ }^{38}$ Joseph C. Dorsey, Slave Traffic in the Age of Abolition: Puerto Rico, West Africa, and the Non-Hispanic Caribbean, 1815-1859 (Gainesville: University Press of Florida, 2003), 1-20, 210-19.

${ }^{39}$ Raquel Rosario Rivera, La real cédula de gracias de 1815 y sus primeros efectos en Puerto Rico (San Juan, 1995). 
Stark studied slave population numbers in the seventeenth and eighteenth centuries. His dissertation evaluated the population, marriage, and family life of freed and enslaved people. He concluded that the drive for marriage depended on religious times of the year. Population growth correlated to the labor, type of plantation, and number of slaves in a region. ${ }^{40}$ Slave and marooned immigration was one of the main themes in his article, "Rescued from their Invisibility: the Afro-Puerto Ricans of Seventeenth-and-Eighteenth Century San Mateo de Cangrejos, Puerto Rico.” To remain in Puerto Rico, marooned and escaped slaves pledged loyalty to Spain and became Catholic. Many settled beside San Juan's city walls, joining the economy and participating in the military. ${ }^{41}$

Lastly, David Martin Stark addressed San Juan's population specifically through the 1673 census to understand why the city was called "a desert." He concluded that much of the population was white and female. He attributed the racial imbalance to slave owners not wishing to reveal their illegally obtained slaves. Women's preference for the white soldiers and men stationed at the fortifications accounted for the unequal sex ratio. Through this census, Stark also drew information about urban life and family structures. Because of limited sources and data, an actual comparative study of San Juan population throughout the seventeenth century was not achievable in his research. Sources explain

\footnotetext{
${ }^{40}$ David Martin Stark, "Family Life of Slaves in Puerto Rico: Demographic Evidence from the Years, 1675-1800" (Ann Arbor: UMI Dissertation Services, 1999), 1-24, 31224.

${ }^{41}$ David Martin Stark, "Rescued from Their Invisiblity: The Afro-Puerto Ricans of Seventeenth-and Eighteenth- Century San Mateo de Cangrejos, Puerto Rico," The Americas 63, no. 4 (April 2007): 551-86.
} 
why some studies do not address the inter-periods in Puerto Rican studies, but do not explain why a later demographic analysis on San Juan has not been explored. ${ }^{42}$

Demography and immigration are relatively new topics in colonial Puerto Rican historiography. The trends pertain to slave trafficking and European migration, caused by push-pull factors. Arturo Morales Carrión, Jorge L. Chinea, and Joseph C. Dorsey each addressed forced migration, contributing to racial, labor, and rural histories. ${ }^{43}$ Other publications, such as Raquel Rosario Rivera, illustrated the population increase caused by changes in administrative decisions. ${ }^{44}$ However, the research limits itself to the Caribbean and specific European countries. ${ }^{45}$ Some publications do have a form of Atlantic perspective, but further research can develop this approach to include North America, other countries in Europe, and Africa. ${ }^{46}$

Part of the objective of the thesis is to discuss the correlation between the increase of San Juan's population and its infrastructure works. Although not a specific study on demography it contributes to broaden the Puerto Rican historiography through analyzing San Juan's demographic growth during the late eighteenth and early nineteenth centuries. One proposed reason for the shift in public works and administrative actions was due to

\footnotetext{
${ }^{42}$ David Martin Stark, "“There is no City Here, but a Desert"”.

${ }^{43}$ Morales Carrión, Puerto Rico and the Non-Hispanic Caribbean; Chinea, Race and Labor in the Hispanic Caribbean; Dorsey, Slave Traffic in the Age of Abolition.

${ }^{44}$ Rosario Rivera, La real cédula de gracias de 1815.

${ }^{45}$ Morales Carrión, Puerto Rico and the Non-Hispanic Caribbean; Chinea, Race and Labor in the Hispanic Caribbean; Dorsey, Slave Traffic in the Age of Abolition; Rosario Rivera, La real cédula de gracias de 1815.

${ }^{46}$ Morales Carrión, Puerto Rico and the Non-Hispanic Caribbean.
} 
the population growth placing pressure on a semi-sustainable system. This reason is particularly true after the Real Cédula de Gracias in 1815. Historical works by Raquel Rosario Rivera, David Martin Stark, and Jorge L. Chinea will factor into this study because of the data and perspectives they utilized through their own research. The thesis functions as a population analysis and its correlation and impact to social and political concerns involving water. ${ }^{47}$

\section{Public Health Historiography}

Public health and medical history are growing fields of study. Some research discusses Puerto Rico's public health measures and decisions. However, this form of study needs expansion to reflect recent historiographical trends through methodologies and approaches. Part of the thesis' objective is to develop a case study, analyzing public health actions to build public works in San Juan, Puerto Rico. It will potentially apply to both public health and Puerto Rico historiographies through similar methods.

As a geographically expansive analysis, Philip D. Curtin's Death by Migration: Europe's Encounter with the Tropical World in the Nineteenth Century illustrated the dangers of European troops in tropical global areas, such as New Zealand and the Caribbean. Curtin argued that the nineteenth century was a particular period of change in medical development, particularly for Europeans. He used quantitative data to interpret the mortality among European troops and how medical technology and practices decreased death in tropical regions. He addressed most tropical areas, allowing for a

${ }^{47}$ Rosario Rivera, La real cédula de gracias de 1815; Chinea, Race and Labor in the Hispanic Caribbean; Stark, "“There is no City Here, but a Desert'." 
comparative analysis of what preventive methods actually work in particular global areas. $^{48}$

As an example of epidemics and public health, two publications studied cholera in the Caribbean. Kenneth F. Kiple wrote an article on the impact of cholera in the Caribbean during the nineteenth century. He followed several cholera outbreaks, demonstrating the high mortality among freed and enslaved Africans compared to the white population. Kiple stated that high mortality related to the number of slaves in the colonies, such as Cuba and Jamaica. Diet factored into the disease's mortality, where low stomach acids could not kill the virus before entering the rest of the body. He also suggested poverty, unsanitary conditions, and the epidemics' paths as other impacts that made the slave population more susceptible. These circumstances resulted in more slaves exposed and dying from cholera. ${ }^{49}$ Ricardo R. Camunas Madera studied Puerto Rico specifically during the 1855 to 1856 epidemic, one of the outbreaks Kiple applied in his analysis. Camunas Madera included how the Real Cédula de Gracias of 1815 added to the cholera epidemic because of slavery growth. Unlike Kiple, he discussed political, social, and economic impacts from mortality, especially the need for labor after the abolition. ${ }^{50}$

${ }^{48}$ Philip D. Curtin, Death by Migration: Europe's Encounter with the Tropical World in the Nineteenth Century (Cambridge: Cambridge University Press, 1989), xii-xviii, 15961.

${ }^{49}$ Kenneth F. Kiple, "Cholera and Race in the Caribbean," Journal of Latin American Studies 17, no. 1 (May 1985): 157-77.

${ }^{50}$ Ricadro R. Camunas Madera, Epidemias, plagas y marginación: la lucha contra la adversidad en Puerto Rico en los siglos XVIII y XIX (Puerto Rico: Editorial Universidad de America, 1992), 7-13. 
Smallpox was another disease commonly associated with the Caribbean. Some studies analyzed the Spanish vaccine proposal to protect the population from further mortality. In 2008, Florida International University Doctorate of Philosophy student Magda Gómez de Cruz completed a comparative study using Venezuela and Cuba to understand public health measures through the smallpox vaccine. She examined the growth of public health and vaccination boards in both colonies during Charles III's reign. Venezuela and Cuba demonstrated the two directions that some colonies pursued to protect their populations. ${ }^{51}$ A similar study on Puerto Rico was published by José Rigau-Pérez in 1995. His narrative described two different smallpox vaccination introductions to the island. The first inoculation arrived from other Caribbean islands. When the Spanish-administrated vaccine arrived, questions rose on the method in which the first inoculation had been given to the population. Several debates followed that suggested re-inoculation to further protect the population from the virus. ${ }^{52}$

Several city-specific analyses have been conducted throughout medical and disease histories. Recently, some of these studies focus more on the public innovations set to prevent and protect the population. J. H. Powell's Bring Out Your Dead: the Great Plague of Yellow Fever in Philadelphia in 1793 is a North American example of a major port city handling an epidemic through a three month period. Although the case study

\footnotetext{
${ }^{51}$ Magda Gómez de Cruz, "Smallpox Vaccination, the Establishment of Vaccination Boards, and State Formation in Venezuela and Cuba in the Nineteenth Century" (Miami: Florida International University, 2008).

${ }^{52}$ José G. Rigau-Pérez, "Surgery at the Service of Theology: Postmortem Cesarean Section in Puerto Rico and the Royal Cedula of 1804," Hispanic American Historical Review 75, no. 3 (August 1995): 377-404.
} 
concentrated on Benjamin Rush and his actions during the epidemic, its broader objective argued the idea of people's fear and the need to understand the unknown. The analysis has the potential to be Atlantically-focused because of the connection between Africans, Europeans, and Caribbean people all affected by mortality in Philadelphia. ${ }^{53}$

One of the most recent studies of public health in current historiographical trend is Adriana María Alzate Echeverri's Suciedad y orden: reformas santiarias borbónicas en la Nueva Granada. She argued that public health reforms were established to handle the filth and smells that contributed to disease and sickness. Places that produced smell and brought concerns, such as cemeteries and taverns, were reorganized and managed in city planning and other projects. Some administrators and other social classes factored social control into the idea to protect the population from what they considered barbaric and savage. ${ }^{54}$

Several studies on Puerto Rico and public health presented ways that disease and medical practices effected the population and society. ${ }^{55}$ However, other avenues may apply to Puerto Rico, as demonstrated by some public health publications. Philip Curtin's study of tropical climates on Europeans suggested a possible correlation among

${ }^{53}$ J. H. Powell, Bring Out Your Dead: The Great Plague of Yellow Fever in Philadelphia in 1793 (Philadelphia: University of Pennsylvania Press, 1949).

${ }^{54}$ Adriana María Alzate Echeverri, Suciedad y orden: reformas sanitarias borboñicas en la Nueva Granada 1760-1810 (Bogotá: Editorial Universidad del Rosario, 2007).

${ }^{55}$ José G. Rigau-Pérez, "The Introduction of Smallpox Vaccine in 1803 and the Adoption of Immunization as a Government Function in Puerto Rico," Hispanic American Historical Review 69, no. 3 (August 1989); Camunas Madera, Epidemias, plagas y marginación. 
Puerto Rican migration, mortality, and public health actions. ${ }^{56}$ Cholera and smallpox were some of the most inflicting diseases in the Caribbean. Other pathogens include yellow fever, dengue fever, and malaria. Many tropical diseases struck the Puerto Rican population throughout the island's history, especially if ecological alterations occurred. Public health studies can analyze Puerto Rico generally or regionally, focusing on urban areas and ports, as demonstrated by J. H. Powell's book. ${ }^{57}$

For the thesis' purposes, public health is a specific example on the shifting of local and imperial perceptions that impacted San Juan. The capital's geographical location made it possible for infections resulting from stagnant water, flooding, drought, and hurricane destruction. The thesis reflects on many methodologies and approaches utilized and suggested by the public health historiography. ${ }^{58}$ It enhances the historical study and creates a complementing work to both Puerto Rican and public health historiographies.

One purpose for the thesis is to contribute to some gaps in the Puerto Rican historiography. Public health remains one area in which research has not discussed its role during modernization, urbanization, and militarization. In urban research, public health plays an important role because the city's survival depends on the population's well-being. During the nineteenth century, San Juan developed into an influential port city in the Caribbean. Unlike the city's past, disease, waste, and other harmful factors

\footnotetext{
${ }^{56}$ Curtin, Death by Migration.

${ }^{57}$ Powell, Bring Out Your Dead.

${ }^{58}$ Alzate Echeverri, Suciedad y orden.
} 
most likely concerned local officials and administrators because it would affect the island's prosperity. This means public health became one focal point in local politics and society. The role of public health in the social and administrative view is a perspective in San Juan's history not well explored and will be supported by the thesis.

The Evolving Fields of Crisis Management and Environmental Histories The thesis will utilize growing fields of crisis management and environmental histories. These research topics evolved from other historiographies over the last ten years, providing new approaches and methodologies to understand the historical significance of major events, such as natural disasters, epidemics, and social and political unrest. Historical trends and contributions are still forming because of the fields' recent developments. However, one common feature between the several publications is their analysis of case-specific events and regions throughout the world and the impact and change they produce.

Environmental history may reflect current scientific studies on climate change. "El Niño, Environmental Crisis, and the Emergence of Alternative Markets in the Hispanic Caribbean, 1760s-70s" by Sherry Johnson related the environment to historical experiences. In the article, Johnson argued that particular climate changes increased hurricane and drought conditions, which in turn affected Spanish provisions and food supply to the Caribbean colonies. During that time, the Spanish Empire restricted the colonies' commercial abilities. However, measures for food and other provisions forced the colonies to trade with other colonies, such as British North America. New 
connections in trade and commerce developed between the Spanish Caribbean colonies and the British colonies, which altered the relationship with Spain. ${ }^{59}$

Hurricanes appear in several environmental studies as having severe and influential impact on the Caribbean region. Matthew Mulcahy and Louis A. Pérez each researched the relationships between hurricanes and Caribbean history. Matthew Mulcahy analyzed social and economic responses to hurricanes in the Greater British Caribbean, spanning from the Lesser Antilles to South Carolina. His study utilized some islands and areas more than others because of the frequency in which hurricanes occurred. The colonies' developmental stages towards a plantation economy also contributed to where Mulcahy concentrated. He argued that hurricanes influenced both the colonies and parts of Europe through expenses and building materials. ${ }^{60}$ Louis A. Pérez argued that three specific hurricanes in the early nineteenth century contributed and encouraged Cuba's independence. He analyzed the changes in trade, plantation agriculture, land, and other parts of society and how they later redeveloped after the hurricanes. These alterations with other social and political events shifted Cuba towards independence. $^{61}$

Stuart B. Schwartz completed a similar study on Puerto Rico. His article evaluated one of the most destructive hurricanes in Puerto Rican history. The importance

\footnotetext{
59 Johnson, "El Niño, Environmental Crisis, and the Emergence of Alternative Markets," 365-410.

${ }^{60}$ Matthew Mulcahy, Hurricanes and Society in the British Greater Caribbean, 16241783 (Baltimore: John Hopkins University Press, 2006), 1-9.

${ }^{61}$ Louis A. Pérez, Winds of Change: Hurricanes and the Transformation of Nineteenth Century Cuba (Chapel Hill: University of North Carolina Press, 2001).
} 
of this particular hurricane related to its arrival after the American invasion and occupation. The hurricane's damage left much of the population homeless and without work. Many parts of the island's infrastructure and buildings were in ruins. Schwartz stated that the funds used to rebuild the island did not correspond to the population's demands, causing apprehension. However, the hurricane forced planters to rely on the United States government and foreign aid for finances, thus strengthening control over the population and their social and economic establishments. ${ }^{62}$

Because of minimal studies on public health or water in San Juan, other historical works provided possible avenues for research. Richard Benedict Gill's The Great Maya Droughts: Water, Life, and Death examined an alternative interpretation to the decline of the Classic Maya Civilization between 800 AD and 1000 AD. Many historians and researchers suggested that the decline was caused by human actions. Gill argued that drought and famine related to climate change resulted in the civilization's collapse. $\mathrm{He}$ utilized several disciplines, such as geology, climate studies, sociology, and archaeology, to establish theories and evidence that climate changes caused the droughts and famines. Gill's book did present other methodologies that were applicable to studying water's role in a society. ${ }^{63}$

Gerard Koeppel's Water for Gotham: a History, narrated the history of New York's water crisis from settlement to the completion of the Croton Water Works. The

${ }^{62}$ Stuart B. Schwartz, "The Hurricane of San Ciriaco: Disaster, Politics, and Society in Puerto Rico, 1899-1901," Hispanic American Historical Review 72, no. 3 (August 1992): 303-34.

${ }^{63}$ Richardson Benedict Gill, The Great Maya Droughts: Water, Life, and Death (Albuquerque: University of New Mexico, 2000). 
author linked bureaucracy, finances, ignorance, and false solutions to why the crisis existed for several centuries. The water condition caused several disease outbreaks, which finally forced local and state officials to find a solution. Croton River was overlooked or dismissed in several proposals until engineers and planners devised a public works project to transport water to the city. What was thought to only take a few years to complete lasted over a decade. After its completion, water was no longer an urban issue, and the public works became a model for following water projects. ${ }^{64}$

\section{Historiographical Contributions}

Colonial Puerto Rican historiographical trends expanded from general syntheses and turn-of-the-century presentations of major historical events. During the late 1970s, many authors introduced research using the rural plantation economy. Embedded in these studies were labor and racial issues, specifically analyzing slavery in Puerto Rico. ${ }^{65}$ Supplementing the rural plantation economies, urban and demographic histories emerged. Urban history continued to study racial and social struggles, but later diverged to include gender, land distribution, and urban institutions. ${ }^{66}$ Demography primarily included the

\footnotetext{
${ }^{64}$ Gerard Koeppel, Water for Gotham: A History (Princeton: Princeton University Press, 2000), 287, 290-92.

${ }^{65}$ Francisco A. Scarano, Sugar and Slavery in Puerto Rico; Picó, Libertad y servidumbre en el Puerto Rico del siglo XIX; Figueroa, Sugar,Slavery, and Freedom; MartínezVergne, Shaping the Discourse on Space.

${ }^{66}$ Matos Rodríguez, Women and Urban Change; Kinsbruner, "Caste and Capitalism in the Caribbean"; Sherry Johnson, "La Guerra Contra los Habitantes de los Arrabales"; Mayo Satana, La esclavitud urbana en San Juan de Puerto Rico; Cubano Iguina, Rituals of Violence in Nineteenth-Century Puerto Rico; Szásadi, "Credit-Without Banking."
} 
slave society and forced African migration for slave labor. ${ }^{67}$ Another demographic approach was Caribbean and European immigrations, especially after changes in Spanish administrative policies. ${ }^{68}$

The history of colonial Puerto Rico continues to include other new emerging fields of study, such as public health and environmental histories. ${ }^{69}$ However, further studies need to extend Puerto Rico's historiography to fill gaps in specific geographic areas and demography. In doing so, the island can be placed within an Atlantic perspective, either as a whole or through defined cities and ports.

Demography, public health, urbanization, politics, society, environment, and economics are addressed in the thesis through the shift towards a public works conscious San Juan. Demography and immigration were analyzed as a city-specific case study, noting changes in politics and society. Public health and works supplement research already completed on medicine and health, while including methodologies developing from the public health field. Some environmental impacts altered administrative and economic systems, requiring management on both local and imperial scales.

${ }^{67}$ Chinea, Race and Labor in the Hispanic Caribbean; Chinea, "Race, Colonial Exploitation and West Indian Immigration in Nineteenth-Century Puerto Rico, 18001850"; Dorsey, Slave Traffic in the Age of Abolition; Morales Carrión, Auge y decadencia de la trata negrera en Puerto Rico (1820-1860); Stark, "Rescued from Their Invisiblity"; Stark, “"There is no City Here, but a Desert"; Stark, "Family Life of Slaves in Puerto Rico."

${ }^{68}$ Morales Carrión, Puerto Rico and the Non-Hispanic Caribbean; Chinea, Race and Labor in the Hispanic Caribbean; Rosario Rivera, La real cédula de gracias de 1815.

${ }^{69}$ Rigau-Pérez, "The Introduction of Smallpox Vaccine in 1803”; Camunas Madera, Epidemias, plagas y marginación; Schwartz, "The Hurricane of San Ciriaco." 
The thesis analyzes the collapse of the old imperial system and the rise of a new, more applicable system for public works in San Juan, Puerto Rico, during the last part of eighteenth and early nineteenth century. Public works and health contain the dynamics to interconnect unrelated disciplines because of its essential need in human survival. Public health, environmental, crisis management, and Puerto Rican historiographies primarily include their own separate trends. Through this thesis, the once separated historiographies are joined by infrastructure and sanitation as focal points, contributing to each topic, filling gaps in other historiographies, and furthering historical research.

\section{Organization of Thesis}

The thesis has been organized into six chapters, an epilogue, and a conclusion that are chronologically and thematically arranged. The six chapters are separated into two parts. Part One analyzes the old-established system built during colonization and its changes following new administrative directives in the late eighteenth century. Chapter 1 sets the background information of Puerto Rican settlement and its slow decline following the exodus to Costa Firme, or the South American mainland, and the limited mercantile exchange with the Spanish Fleet System. From 1530 to 1765, Puerto Rico became a forgotten military outpost that contained potential geographic and economic benefits for the Spanish Empire that was never used. Chapter 2 discusses the Bourbon Reforms, a new centralized form of royal governance over the Spanish Empire. Following the Spanish defeat in Cuba, the Bourbon Reforms are applied to the Caribbean for military purposes, and new attention by Field Marshal Alejandro O’Reilly gives Puerto Rico new life. His purposed economic plans for the island were not applied as 
advised, but begin to alter the semi-sustainable economic and public works system established for the previous 250 years. Chapter 3 looks specifically at the public works and sanitation's conditions following 250 years of neglect and misuse. Although new changes occurred in San Juan following O'Reilly's recommendations, ecological disasters hindered public works conditions and exposed the population to damaging pathogens. They also destroyed part of the existing infrastructure, forcing administrative attention to these issues during times of catastrophes.

Part Two of the thesis analyses the early nineteenth century. It studies the destruction of the established system and the elements that contributed to the building of the new prosperous system. In Chapter 4, following ecological destruction and overuse, public works began to decay while the local and colonial administration continued its military conscious infrastructure. Undependable external finances and new expenses enforced by new public health efforts caused the colonial system in island to collapse. Chapter 5 illustrates the first constitutional government following the Napoleonic Invasion of Spain. With no oversea authority to support the economy, the local elected official began public works projects focused more on the welfare of the capital's inhabitants rather than on the military initiatives. As Costa Firme colonies declared independence from Spain, Puerto Rico remained loyal to the monarchy, earning a new power position in the empire. Lastly, Chapter 6 presents a new San Juan and Puerto Rico given new attention due to its strategic location within the Spanish Empire. New royal decrees and unrestricted commerce brought new economic opportunities to form plantation estates. Fleeing loyalists with agricultural background from Costa Firme caused a population explosion in San Juan and the rest of the island. With the increase of 
internal income and royal consciousness, public works exploded throughout the capital. However, pervious initiatives by the constitutional government and past administrations had been neglected or altered. To prevent a possible revolution, the proper necessities needed by the growing population became the main focus, giving public works and sanitations the first head-on attention to the island's development.

Between 1765 and 1823, San Juan was transformed from a forgotten military base to a prosperous, modern capital in the Spanish Empire. With this transition, the political, demographic, economic, geographic, and medical systems were altered entirely. They turned into a new system supportive of infrastructure and sanitation improvements for the city's population. By analyzing the local and royal administration in regards to potable water, street infrastructure, and public health, a more interdisciplinary insight of San Juan's modernization and development will be established. 
Depending on the area's geography and the political socio-economic responses, natural and manmade occurrences may threaten human survival in a new settlement. In the case of Puerto Rico, the environment played an influential role in the island's settlement and population growth. Disease and other natural disasters threatened European colonization due to its tropical climate. The island's Caribbean location affected its economic and demographic growth following Spanish colonization in the sixteenth century. As the Spanish Monarch established its American empire, Puerto Rico's location also directed its political purpose for the next 250 years. Existing colonists were able to survive and establish a defensive stronghold because of the Puerto Rico's beneficial qualities. However, the Hispanic Caribbean settlement was not fully exploited until the nineteenth century.

\section{Puerto Rico's Adaptable Geography}

Puerto Rico is one of the most eastward of the Greater Antilles islands, following Cuba and Hispaniola, in the Caribbean Sea. Its east to west length calculates up to 90 miles, while its width ranges 33 miles. The island's total landmass expands to 2,970 square miles, with a varied geography of numerous mountains, rivers, forests, and plains. Due to these characteristics, Puerto Rico's environment provided more to its colonial population when compared to any other Caribbean island. Smaller islands did not 
contain large amounts of water and timber, forcing them to rely on other colonies for basic provisions, especially during times of drought. ${ }^{70}$

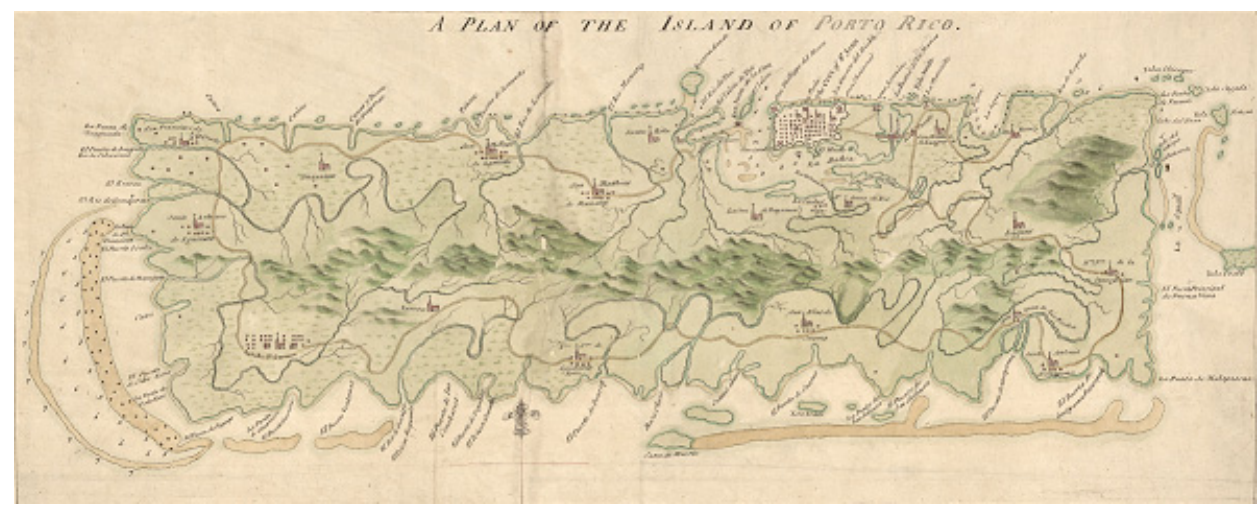

Part of "A Plan of the Island of Porto Rico," Library of Congress, 1760s. ${ }^{71}$

Although tropically located, Puerto Rico's climate depends on the island region and geography. The island's topography and vegetation benefits rain clouds formation, unlike many Caribbean islands that lack mountains and forest. The other islands experience more frequent drought conditions. ${ }^{72}$ Temperatures range between 70 and 95 degrees Fahrenheit throughout the year with June, July, and August being the harshest with constant sun and humidity during the day. Throughout the remainder of the year, Puerto Rico's climate remains calm with some rainfall and winds. The southern coast's precipitation is infrequent and may not fall for several months as a result of the mountain shadow effect contributed to the linear mountain ranges across the island. In comparison,

\footnotetext{
${ }^{70}$ Flinter, An Account of the Present State of the Island of Puerto Rico, 18-19.

71 "A Plan of the Island of Porto Rico." Vault: Howe 49. American Memory. Library of Congress. (Washington D.C.: Library of Congress, 1760s).

${ }^{72}$ Ibid, 51.
} 
the northern coast benefits more from the mountain shadow effect by receiving more rainfall and for longer calendar periods. ${ }^{73}$ The island's north coast may experience so much rainfall from passing storms to cause river banks and low lying areas to flood. ${ }^{74}$

The island's land features affects the climate and the inhabitant's health. Puerto Rico's mountains and continuously flowing rivers promote lower amounts of stagnate water and usually protects the population from possible disease. The geographical difference from other Caribbean islands produces different seasonal weather and alleviates the extreme heat and rains. Winds cool the valley regions, making the climate bearable. Colonel George D. Flinter, an observer for the Spanish Queen Isabella II and retired British officer, recommended the island to Europeans in 1834. Even though it did not follow the different seasons accustomed to most European regions, the extremes were not as inflicting to its population's health. ${ }^{75}$ His suggestion illustrated that, although in a tropical region, Puerto Rico was more acclimatizable for non-indigenous people than other islands in the Caribbean.

Puerto Rico's geography and climate correlated to its growing development in the late eighteenth and nineteenth centuries. While prone to hurricanes, droughts, and earthquakes, the island contained promising environments that could have made it a successful, self-sufficient colony. However, Spanish colonial officials and Puerto Rico's inhabitants rarely utilized its beneficial qualities until the mid-nineteenth century. The possible hindrances existing on the tropical island could have been resolved through

\footnotetext{
${ }^{73}$ Ibid, 47, 51.

${ }^{74}$ Ibid, 49.

${ }^{75}$ Ibid, 46-47.
} 
infrastructure and public works. Even in its European establishment, Puerto Rico's positive contributions were minimally exploited because of differing political aspirations and settler underdevelopment.

San Juan, Puerto Rico's Early History and the Development of a Dependent Military Outpost

Christopher Columbus claimed San Juan Bautista de Puerto Rico for Spain on November 19, 1493, during his second voyage to the Americas. Prior to his arrival, the Taino, one of the original Native American groups inhabiting the island, referred to it as Boriquén or Borikén. Following Columbus' claim, many Spanish conquistadors overlooked the island, even after the Spanish monarch encouraged settlement in 1505. Finally by 1508, colonization occurred under the leadership of Juan Ponce de León, who directed over fifty men from Santo Domingo, Hispaniola, to settle and search for gold on Puerto Rico. ${ }^{76}$ Ponce de León established the island's first capital, Caparra. In 1526, the Spanish King ordered the settlement be moved to the island's northern coast islet, constructing the new capital now known as San Juan Bautista. ${ }^{77}$

The capital's new location contained several benefits. San Juan occupied the north end of the three-mile long islet, positioned on a slope for possible expansion, wind flowed from the sea, and less encumbered by insects. ${ }^{78}$ It allowed for an easily

\footnotetext{
${ }^{76}$ James L. Dietz, Economic History of Puerto Rico: Institutional Change and Capitalist Development (Princeton: Princeton University Press, 1986), 3.

${ }^{77}$ Abbad y Lasiera, Historia geográfica, 11, 72.

${ }^{78}$ Ibid, 99, 101.
} 
assessable, but defendable harbor. ${ }^{79}$ San Juan continued to expand throughout the sixteenth century, reaching an estimated 1,000 residents in 1575 and 1,600 people by $1604{ }^{80}$ However, despite expansion, the islet did not provide a large landmass capable of supporting the agricultural accommodations required for the capital's population. In prospective, this meant San Juan residents relied heavily on imported food from the main island, yet secured its position as the colony's main civil, military, and religious center. ${ }^{81}$

Gold primarily drove Spanish interest in early occupied Puerto Rico, which contained easily minable gold seams, which were exhausted by the mid-1530s. For labor, Spanish settlers utilized the native population, often imported from other neighboring islands after the existing population had been overworked or died from pathogens. These Native American populations did not disappear as suspected by many Spanish contemporaries, but declined in number, fleeing into the mountains or other neighboring islands, or intermarrying with Spanish colonists. The early conquistadors relied more on the local population because of the African slave importation costs. African slaves were primarily used as herders and food producers on Puerto Rico. ${ }^{82}$

The mid-sixteenth century gold exhaustion affected settler migration, causing a decline in new colonists. ${ }^{83}$ Puerto Rico's population began to drop following a mass exodus to other parts of the Spanish Empire. Settler emigration became so common that

\footnotetext{
${ }^{79}$ Stark, “"There is No City Here, but a Desert', 257.

${ }^{80}$ de Hostos, Historia de San Juan ciudad murada, 21.

${ }^{81}$ Stark, “"There is No City Here, but a Desert', 257.

${ }^{82}$ Dietz, Economic History of Puerto Rico, 6.

${ }^{83}$ Scarano, Sugar and Slavery in Puerto Rico, 4.
} 
local officials applied strict measures to force the population to stay, including death penalties and removing bodily limbs. In 1530 the governor recorded 3,040 people, including 1,148 Native Americans and 1,523 African slaves. By the end of the century, official census stated the island had only reached 3,600 inhabitants. ${ }^{84}$

Puerto Rican migrants recognized and followed the Spanish monarchy's attention to Costa Firme or the American mainland of New Spain, Central America, and South America, particularly Peru. New Spain and Peru contained larger amounts of mineral wealth, specifically silver mines essential to pay Spain's debt for its constant European wars. ${ }^{85}$ Spain's political attention thus meant declining opportunities for the Caribbean islands. Costa Firme's immediate wealth attracted the Spanish Monarch's attention away from the Caribbean. As a result, the Hispanic island territories suffered neglect through the remaining sixteenth and seventeenth centuries. ${ }^{86}$

Puerto Rico's residual colonists found other economic methods through commercial crops and provisions. Because of constant trade with Seville, colonists survived by producing agricultural goods, such as ginger, cow hides, and some sugar. ${ }^{87}$ Herders and ranchers also utilized land grant concessions from the Spanish Monarch and local cabildo, or town councils, on the island. Land opportunities ended when ranchers illegally occupied Spanish Monarchy land. Charles V in 1541 declared public use of

\footnotetext{
${ }^{84}$ Dietz, Economic History of Puerto Rico, 6.

${ }^{85}$ Ortiz, Eighteenth-Century Reforms in the Caribbean, 43.

${ }^{86}$ Ibid, 44.

${ }^{87}$ Scarano, Sugar and Slavery in Puerto Rico, 7.
} 
pasture land, forest, and water areas. Philip II followed by voiding the cabildo's land grants. $^{88}$

The commercial mode of production also decreased following the development of the Spanish Fleet System, requiring ships to travel in large numbers to deter piracy and to travel at specific intervals from Seville to limited American ports. Havana, Cuba, benefitted economically from this system because its port was the meeting location for the two separate fleets on their spring return. However, Puerto Rico's geographic location hindered its ability to take advantage of Spanish shipping, further isolating the Caribbean island. ${ }^{89}$ The small, existing agricultural centers shrank to sustainable living. The Puerto Rican population survived using non-Hispanic contraband trade, while its subsistence economy relied on trading timber, cattle, and some agricultural products for European manufactured goods. ${ }^{90}$ Trade limitation continued into the eighteenth century when the Spanish Monarch stated trade could only occur with Seville using Spanish merchants and vessels. ${ }^{91}$

Although the shipping changes affected the commercial production in Puerto Rico, the island's purpose shifted toward an important military and defensive base for passing trading ships. Puerto Rico and Cuba acted as strongholds against non-Hispanic pirates and privateers in the Caribbean. In response, several European empires attacked

\footnotetext{
${ }^{88}$ Ortiz, Eighteenth-Century Reforms in the Caribbean, 45.

${ }^{89}$ Ortiz, Eighteenth-Century Reforms in the Caribbean, 51; Scarano, Sugar and Slavery in Puerto Rico, 7.

${ }^{90}$ Scarano, Sugar and Slavery in Puerto Rico, 7.

${ }^{91}$ Dietz, Economic History of Puerto Rico, 9.
} 
the island in the sixteenth and seventeenth centuries, aiming to remove the military outpost and obtain more land. France struck in 1528 and 1539, encouraging the Spanish monarchy to build El Morro Fortress in San Juan to protect the harbor from further raids. English forces failed to capture the island in 1595, but were successful in 1598. England almost converted Puerto Rico to one of its own Caribbean possessions following a threemonth occupation period. ${ }^{92}$ The Spanish territory was only saved after the English military, led by George Clifford, was devastated by an epidemic. ${ }^{93}$ General Boudewijn Hendriksz, rather than claiming San Juan for the Dutch in 1625, pillaged and burnt much of the city to the ground. ${ }^{94}$ The last attack caused Spanish officials to instruct residents to build a defensive wall to protect them from future invasions. ${ }^{95}$ Although the project began in 1630, it would take until the 1780's to finish, with some work completed in short intervals during those 150 years. ${ }^{96}$

Because of economic stagnation, minimal mineral wealth, and changing political focus, Puerto Rico, like other Hispanic Caribbean islands, did not contain the funds to support its new role as a military outpost. The Spanish Monarch recognized this issue in 1589 and established the situado, an annual delivery of New Spain funds from its mines and royal treasury, to supplement soldier pay and fortification works. The situado meant

${ }^{92}$ Ibid, 8.

${ }^{93}$ Stark, "“There is No City Here, but a Desert'," 258.

94 Stark, "“There is No City Here, but a Desert"”, 258; Dietz, Economic History of Puerto Rico, 8 .

${ }^{95}$ Dietz, Economic History of Puerto Rico, 8.

${ }^{96}$ Stark, “"There is No City Here, but a Desert"”,258 
a reliance on New Spain's finances and its timely deliveries each year. Many times between the seventeenth and eighteenth centuries, delays or piracy hindered the situado shipments. In some cases, the deliveries also arrived incomplete, varying year to year. ${ }^{97}$ If in desperate need, Puerto Rico's governor could receive funding from the Deposito de Guatemala, an emergency fund from Guatemala's royal treasury, but that too could be delayed, denied, or incomplete. ${ }^{98}$ Shipment variations throughout the seventeenth century resembled other Hispanic colonies in the region. Puerto Rico and Florida both experienced amounts ranging from 10,000 to 80,000 pesos, rarely receiving their allotted amounts for each year. ${ }^{99}$

Furthermore, the situado external funds provided the largest currency flow in Puerto Rico's economy, despite some internal financial growth. Puerto Rico's internal revenue included general and special funds. General funds included selling administration offices, the almojarifazgo, or import-export taxes, alcabala, or general sales tax, and other taxes on liquor and gambling. Slave importation produced income by charging 40 pesos per slave payable to local funds. Special funds held specific purposes, such as tithes for the Catholic Church, selling Church offices, and other defense funding outside the situado. ${ }^{100}$

${ }^{97}$ Ortiz, Eighteenth-Century Reforms in the Caribbean, 54-55.

${ }^{98}$ Ibid, 158-159.

${ }^{99}$ López Cantos, Historia de Puerto Rico, 96-97; Amy Turner Bushnell, Situado and Sabana: Spain's Support System for the Presidio and Mission Provinces of Florida, (Athens: University of Georgia Press, 1994), 47.

${ }^{100}$ Ibid, 158. 
The internal revenue paid for many non-military projects within San Juan and the island, including public works. Nonetheless, the situado provided more assets than the domestic revenue. The situado's economic influence also created crises when it arrived late or incomplete, especially in San Juan. ${ }^{101}$ Because San Juan was the capital and main military stronghold, the external financial gains did stimulate some economic growth. Fortification projects required local residents to provide materials and a labor force. In response, other goods and services improved in San Juan, but at the cost and minimal growth of the island's outlying areas. ${ }^{102}$

As a result of economic decline, shifting political attention, and becoming a military outpost, Puerto Rico continued to stagnate throughout the seventeenth and early eighteenth centuries. By 1673, a Spanish contemporary stated that San Juan had become a desert because the major urban center on the island had been overlooked by shipping and the Spanish monarchy. ${ }^{103}$ For example, between 1651 and 1662, no registered Spanish ships arrived at Puerto Rico, and by 1675 , only eight Seville ships were received at port. ${ }^{104}$ The situado only hindered the economy as it would not arrive for decades. As a result, royal and local officials spent many years without salaries and forced residents to depend on credit to buy goods. ${ }^{105}$

\footnotetext{
${ }^{101}$ Ibid, 54.

102 Stark, "“There is No City Here, but a Desert'," 258

${ }^{103}$ Ibid, 256.

104 Ibid, 259.

105 Ibid, 259.
} 
San Juan's Structure and Status, 1604-1765

The capital's demography between the seventeenth and eighteenth centuries reflected its economic and military situations. San Juan's population ranged between 1,600 people in 1604 and 1,794 people in 1673, not including children less than ten years of age. San Juan's demography also resembled other Caribbean islands during the same time period and was even considered more populated. Port Royal, Jamaica, numbered 1,981 inhabitants in 1673, while Santo Domingo, Hispaniola only contained 582 people in 1681. In contrast, Havana included over 1,000 heads of household alone in $1662 .{ }^{106}$

By 1765, 4,506 residents lived in San Juan, distributed between 3,562 free people and 944 enslaved. ${ }^{107}$ The population slowly rose in the following decades as more military personnel and settlers arrived in the area. By 1783, the population peaked at 6,462 inhabitants, before shrinking the first decade of the nineteenth century. ${ }^{108}$ Even by the end of the eighteenth century, Puerto Rico's capital was small compared to Havana, with an estimated population of 35,000 to as much as 60,000 in $1763 .{ }^{109}$

During the early eighteenth century San Juan physically consisted of six streets running north-south with seven perpendicular streets, dividing the island's capital into four barrios. Access to the main island other than by boat relied on two roadways on

${ }^{106}$ Ibid, 262.

${ }^{107}$ Alejandro O'Reilly, "Memoria de D. Alejandro O'Reilly a S. M. sobre la isla de Puerto Rico, en 1765," in Boletín histórico de Puerto Rico, Cayetano Coll y Toste, ed. (San Juan: Academia Puertorriqueña de la Historia, 1972), 116-17.

${ }^{108}$ Adolfo de Hostos, Crecimiento y desarrollo de la ciudad de San Juan (San Juan: Instituto de Cultura Puertorriqueña, 1957), 21.

${ }^{109}$ Sherry Johnson, The Social Transformation of Eighteenth-Century Cuba (Gainesville: University of Florida Press, 2001), 23. 
either end of the islet. ${ }^{110}$ In size, the capital was small in comparison to Kingston, which measured at least half a mile in length, and other Caribbean capitals. However, San Juan was restricted by the islet landmass and required main island expansion to grow. ${ }^{111}$

Structures within the city reflected its landmass compression. Streets were narrow, only allowing some front accesses to buildings. However, most buildings utilized the deep space behind building fronts, usually containing gardens and patios. Structures were typically single story and small in size. Important government houses and the higher classes enjoyed taller homes built of stone and tile. The more general population primarily lived in wooden and straw huts. ${ }^{112}$

Sixteenth-century San Juan resembled late eighteenth-century San Juan. Most existing infrastructure supported the capital since the population remained almost static. Basic necessities were supplied by public works built during the early sixteenth century, prior to the island's economic decline. The existing public works system served its purpose, unless when repairs were required. Even if pressure occurred for more development, the political and economic system limited its possible attention, especially during a time when military defense overshadowed general development and consumed most available funds.

To build public works involved several local political organizations within San Juan. The Governor Captain General appointed by the monarchy, was the highest official on the island and commanded the stationed army and militia. Following the eighteenth-

\footnotetext{
${ }^{110}$ Abbad y Lasiera, Historia geográfica, 99.

${ }^{111}$ Stark, “'There is No City Here, but a Desert',” 260.

${ }^{112}$ Ibid, 260.
} 
century Bourbon Reforms, the Puerto Rican Governor also became the intendant, handling financial and war decisions, giving him full control of the Real Hacienda, Puerto Rico's royal treasury. Most governors were usually military trained, influencing their civic judgment. The connected roles allowed Puerto Rico's Governor to centralize power over other local political institutions, especially as designed in the Bourbon Reforms. ${ }^{113}$ The governor's character differed in Cuba. The Spanish Monarchy sent royal bureaucrats to Cuba to serve as governor given a different outcome to colonial rule. $^{114}$

The cabildo served as the next major political level on the island. Depending on the colony, the cabildo could also be the municipal government or ayuntamiento for a particular town. To serve within the cabildo and other municipal offices, members were required to be Spanish citizens, excluding the African population both free and enslaved, mulattos, and non-citizens. ${ }^{115}$ In 1765, Puerto Rico had two regional cabildos, one located in San Germán on the island's southwestern coast and the other in San Juan. San Juan's cabildo controlled much of Puerto Rico's eastern region to the southern coast. It consisted of two alcaldes ordinarios (executive magistrates), six regidores (alderman),

${ }^{113}$ Arturo Morales Carrión and María Teresa Babín, Puerto Rico: a Political and Cultural History (New York: W.W. Norton, 1983), 79.

${ }^{114}$ Johnson, Social Transformation of Eighteenth-Century Cuba.

${ }^{115}$ Kinsbruner, The Colonial Spanish-American City, 36. In some cases, ayuntamiento and cabildo were used interchangeably for the same administrative body. San Juan primary sources sometimes did this when administrators wished to state their relation to the capital city or to the region they represented. Some primary sources also suggested that there was a smaller, contributing body in San Juan called the ayuntamiento that supported and submitted information to the cabildo. 
two alcaldes de la hermandad (magistrates with restricted influence), a procurador general síndico (procurator), and a scribe. ${ }^{116}$ The two alcaldes ordinarios represented magistrates, with the first elected alcalde ordinario as the main serving official. ${ }^{117}$

The regidores and alcaldes de la hermandad comprised the majority of the cabildo as alderman. The procurador general síndico aided the alcaldes ordinarios as a trustee attorney, providing requested legal counsel. Other offices throughout San Juan reported to the cabildo, such as alférez real or royal standard bearer, the alguacil mayor or chief constable, field ejecutor (inspector) in charge of inspecting weighting and goods, and the alcalde de barrios, magistrate officials elected to represent the four individual barrios within San Juan. Each reported to the cabildo and the ayuntamiento. ${ }^{118}$

For San Juan's public works, the cabildo communicated between the capital's barrios and the Governor. They appealed for civilian infrastructure, served as a residential representative board, and acted as directors, ordering and assigning workers to projects. ${ }^{119}$ The political organization was still restricted by the political directions enforced by the Governor and Spanish Monarch. The cabildo was required to follow the Governor's request, even if it included revoking internal development.

San Juan's environment and early history established an existing system that developed the island into a military outpost with a small subsistence lifestyle. Although

\footnotetext{
${ }^{116}$ Abbad y Lasiera, Historia geográfica, 146-47; Kinsbruner, The Colonial SpanishAmerican City, 33-34.

${ }^{117}$ Kinsbruner, The Colonial Spanish-American City, 33-34.

${ }^{118}$ Ibid, 33-34.

${ }^{119}$ Ibid, 36.
} 
the climate and geography contained benefits that the Spanish Empire could utilize, political and economic direction driven by mineral wealth and a monopoly fleet system strained development. Those same factors also contributed to the island's role as a defensive adversary following several non-Hispanic attacks. To support the military strength, Spanish officials established the situado to pay for salaries and fortification construction. The situado caused Puerto Rico, and specifically San Juan, to be economically dependent on external finances. Following the short-lived demographic explosion in the early sixteenth century, Puerto Rico stayed at a constant demographic rate, even though the capital compared well to other Caribbean cities. That same constant rate in San Juan meant the existing public works built during the island early history supported the residents. As long as there were no changes to the established system, San Juan's citizens would not require further public works for their basic survival. 


\section{CHAPTER 2: PUERTO RICO'S BOURBON REFORMS AND PROPOSED ECONOMIC POTENTIAL, 1765-1797}

For several centuries, San Juan, Puerto Rico, successfully supported its population through an established system supported by external funding and little monarchical involvement. The capital stood as a military outpost within the Spanish Caribbean Empire. ${ }^{120}$ The eighteenth-century Bourbon Reforms reintroduced Puerto Rico to a revitalized relationship with the Spanish monarchy through militarization and potential economic growth, beginning a rippling effect that would ultimately end the previously established system present for over 250 years.

\section{Spain's Bourbon Reforms and their American Application}

In the early eighteenth century, the Spanish Bourbon monarchs, influenced by Enlightenment ideas, applied a series of reforms to develop Spain, and later, its empire. The Bourbon Reforms provided the foundation for prosperity and better conditions for Spain. The reform's goal required a more centralized government that weakened other institutions within the empire, such as the Catholic Church and local colonial councils. It also instituted absolute uniformity to further control these other conflicting powers. ${ }^{121}$

The Seven Years War between the British and the French precipitated the Spanish Bourbon Reforms within the Americas. The Spanish Empire joined the French cause, and its colonies became victims of British attacks. Britain's naval forces captured Havana and plundered Manila in 1762. Havana returned to Spanish hands with the

${ }^{120}$ Ortiz, Eighteenth-Century Reforms in the Caribbean, 65.

${ }^{121}$ Ibid, 22-23. 
Treaty of Paris, but at the loss of Spanish North American territories within Mississippi and Florida. France annexed Louisiana to Spain for its war contribution. However, Havana's capture illustrated the Spanish colonies' weaknesses to foreign attacks. Immediately, Charles III convened a special committee called the Junta Interministerial to strengthen military forces and navy within the American colonies. The committee decided to apply the Bourbon Reforms to the colonial empire. For the desired military reform, the current economic system required changes for better efficiency and income for troops and fortifications development. ${ }^{122}$

The Bourbon monarchy improved the empire's economy by dismissing many archaic monopolies and limitations present since the sixteenth century. The Spanish government abolished the Spanish Fleet System, although still restricted non-Hispanic nations access to colonial ports. Newly established Spanish commercial companies enjoyed the reduced taxes on goods. Free trade still relied on the Spanish economy specifically at Spanish American and Iberian ports. ${ }^{123}$ Spanish colonial institutions were centralized and uniform, developing more proficient civil and financial administrations. The new intendancy system allowed a royal official to govern finances and war specifically. The new administrative system contributed to the rebirth of the cabildo, or local regional or municipal councils, within the colonies. The cabildos became more active in local decisions and urban development. ${ }^{124}$

${ }^{122}$ Ibid, 24-25.

${ }^{123}$ Ibid, 29-30.

${ }^{124}$ Ibid, 33-35. 
For the Caribbean region, Charles III appointed Field Marshal Alejandro O'Reilly, an Irishman loyal to the Spanish crown, to inspect and improve military fortifications and structures. His expedition began in Cuba in 1763, developing Havana's defenses and the army to avoid another foreign occupation. ${ }^{125}$ After reforming the military infrastructure in Cuba, O'Reilly turned to Puerto Rico, arriving in San Juan in 1765. He would continue as an influential contributor to Spanish New Orleans following his Puerto Rican military improvements. ${ }^{126}$

\section{Field Marshal Alejandro O'Reilly Bourbon Analysis of Puerto Rico}

Field Marshal Alejandro O'Reilly's objectives in Puerto Rico included developing a self-sustaining economy that no longer depended on the royal treasury. At the beginning of his economic report, "Memory of Don Alejandro O'Reilly to his Majesty over the Island of Puerto Rico in 1765," he commented on Spain's financial burden because Puerto Rico had depended on New Spain's payments for over the last 250 years. ${ }^{127}$ O'Reilly referred to the situado, an annual financial withdraw from New Spain's royal treasury from the viceroy's mining facilities. It compensated Spanish Caribbean colonies' stationed military and fortifications. The financial support began in 1589 in Puerto Rico after colonial governments determined that the Caribbean colonies lacked mineral deposits and heavily relied on a monoculture economy. The colonial administration believed that the Caribbean colonies could handle yearly costs and

${ }^{125}$ Torres Ramírez, Alejandro O'Reilly en las Indias, 17-52.

${ }^{126}$ Ortiz, Eighteenth-Century Reforms in the Caribbean, 26.

127 O’Reilly, “Memoria de D. Alejandro O'Reilly,"108. 
expenditures using the situado and the little revenue generated by taxes and selling

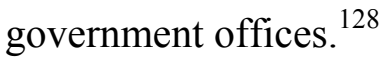

Puerto Rico’s 1764 income reflected Field Marshal Alejandro O’Reilly’s demands for financial change. The allotted situado amounted to 80,000 pesos for military personnel and buildings, but the island's taxation revenue only generated 10,804 pesos. The revenue included 1,372 pesos from the alcabala and 3,617 reales, $61 / 5$ maravedíes generated by the almojarifazgo. ${ }^{129}$ For O'Reilly's Bourbon objectives, these amounts would not produce the assets desired for military reform, thus economic reform was essential.

The 1765 report to the Spanish King, Charles III, examined Puerto Rico's political, social, and economic state. Alejandro O'Reilly described the general population by their clothing, work habits, miscegenation, education, and poor status, especially their unproductive use of abundant land. For over 250 years, the Puerto Rican population remained isolated from much of the Spanish Empire, except when deserters, stowaways, and slave runaways from neighboring Caribbean islands increased the population. O’Reilly acknowledged Puerto Rican residents as Spanish vassals, but described them as non-civilized people. To him, they should cultivate the fertile land for Spain. The field marshal considered this a more respectable action rather than living in

${ }^{128}$ Ortiz, Eighteenth-Century Reforms in the Caribbean, 54-55.

${ }^{129}$ Torres Ramírez, Alejandro O'Reilly en las Indias, 70-71. 
low-standard housing and working without taking advantage of the fruit and land abundance. ${ }^{130}$

Alejandro O'Reilly analyzed the local government and their directions, noting the need for change. He criticized the local government's faulty unreachable conclusions, but believed it could be the main force for improvement and success. The king also needed to give direction through land reform, increase Catholic presence to guide the general population spiritually, and draft new laws that encouraged more immigration and commerce. Through political involvement, local governments could transform the island from a military outpost into a wealthy colony. ${ }^{131}$

The contraband trade removed many Spanish profits present on the island. Throughout the last 250 years, the Puerto Rican inhabitants used illegal trade to obtain essential goods from non-Hispanic powers, in some cases Spain's European adversaries. ${ }^{132}$ Field Marshal O'Reilly knew the trade harmed Spain's royal treasury and merchants, although its legal trade minimally provisioned necessities, such as foodstuffs and clothing. ${ }^{133}$ Contraband filled a void left by the Spanish, but hindered the island's possible advancements. O'Reilly recommended methods to remove the contraband's strength by encouraging the domestic economic development through land reform and agriculture, while Spanish merchants supplied the island's needs. ${ }^{134}$

${ }^{130}$ Ortiz, Eighteenth-Century Reforms in the Caribbean, 111-12, 155.

${ }^{131}$ Ibid, 110.

${ }^{132}$ O’Reilly, “Memoria de D. Alejandro O’Reilly,” 109-10, 122-23.

${ }^{133}$ Ibid, 109-10.

${ }^{134}$ Ibid, 109-10, 122-23. 
Natural resources and potential plantation agriculture held the most promising component in Puerto Rico's development. The abundance of water and fertile land held potential to grow maize, rice, cotton, indigo, sugar, coffee, and other major commodities desired by Spain and Europe. The contraband trade took advantage of the minimally cultivated cash crops, but the island's resources and diversity promised more. O'Reilly stressed the colony's needs for skilled, knowledgeable agriculturists and workers to immigrate and settle unclaimed land. These immigrants desired capital and new regulations that would allow refineries and commercial abilities. The current population would then join after learning proper plantation methods from the arriving skilled settlers. ${ }^{135}$

Field Marshal Alejandro O'Reilly believed Puerto Rico could be self-sustainable without New Spain's situado and other royal funding, if given the proposed freedoms. The economic returns would increase Puerto Rico's own financial needs and return commodities and funds to the royal conifers. His intentions included a more liberal form of economics and commerce. It also requested a more active, centralized political role following specific guidelines. ${ }^{136}$

\section{Outcomes of the Bourbon Reforms in Puerto Rico}

Actual economic reforms differed from Alejandro O'Reilly's proposals. Puerto Rico progressed some, reaching its peak in 1785 when instituting the Real Factoria, which were new trade agreements with the Netherlands for agricultural goods.

${ }^{135}$ Ibid, 108, 114,123-24.

${ }^{136}$ Ortiz, Eighteenth-Century Reforms in the Caribbean, 112-14. 
Commerce permitted the importation of basic essentials, such as foodstuffs and clothing. Slave trafficking and other forms of commerce increased the trade revenue from 1,200 pesos in 1765 to 16,000 pesos in $1778 .{ }^{137}$ Some economic reforms occurred under Coronel Don Miguel de Muesas' governorship between 1769 and 1776. His colonial government encouraged commercial land reform and agricultural production, as suggested by O'Reilly. Muesas furthered these reforms and limited the contraband trade. As a result, the island's internal economy and agriculture grew, but at a slow rate. ${ }^{138}$

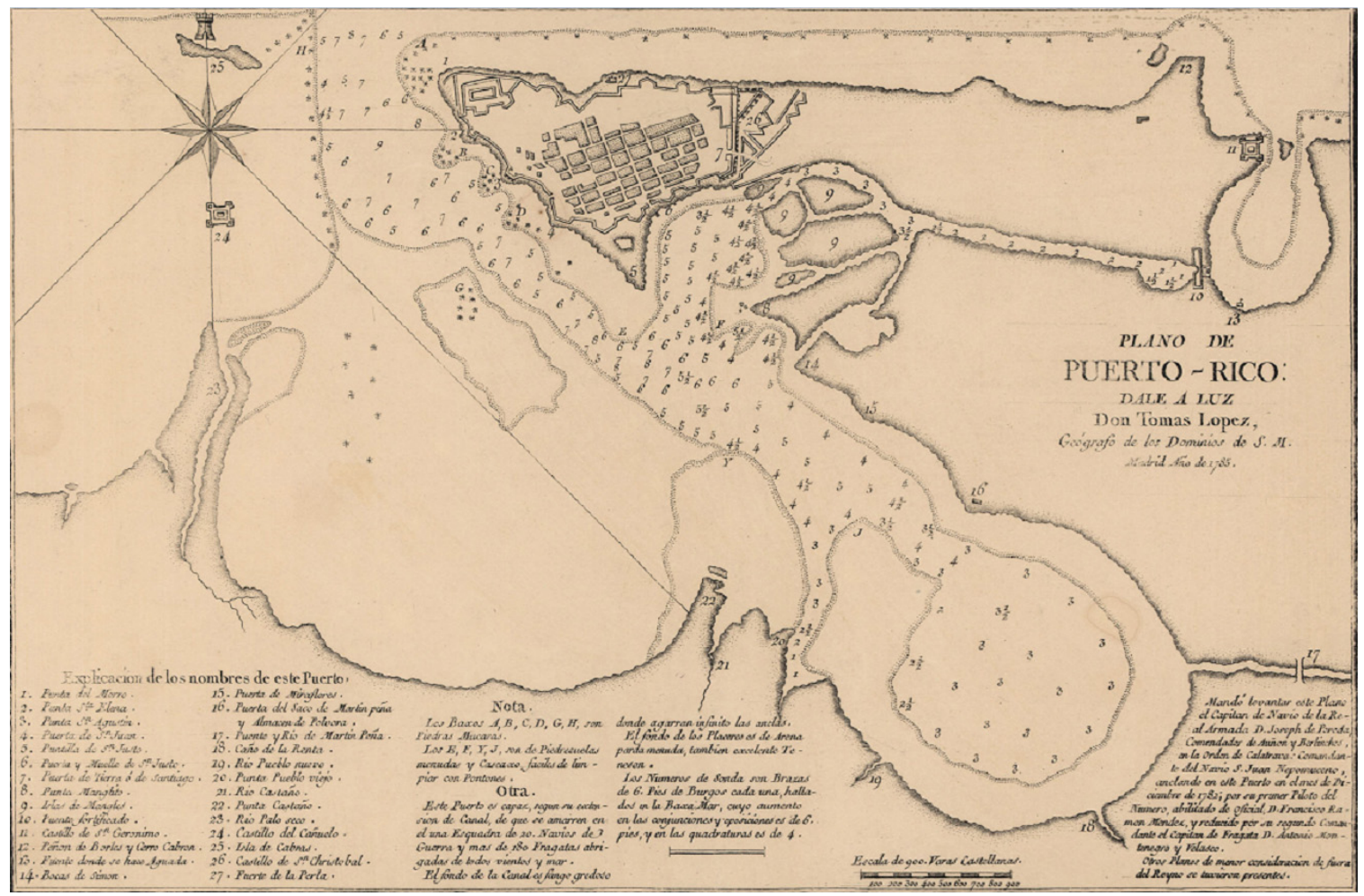

Part of "Plano de Puerto Rico" by Tomás López de Vargas Machuca, Library of Congress, $1785 .{ }^{139}$

${ }^{137}$ Morales Carrión and Teresa Babín, 52-53.

${ }^{138}$ Ortiz, Eighteenth-Century Reforms in the Caribbean, 188.

${ }^{139}$ López de Vargas Machuca, Tomás. "Plano de Puerto Rico." American Memory. Library of Congress. (Washington D.C.: Library of Congress, 1785). 
As originally intended by the Bourbon Reforms, Alejandro O'Reilly proposed several changes to San Juan's defenses in Instrucción al Gobernador de Puerto Rico. It contained instructions for Puerto Rico's governors on fortification improvement plans within San Juan. ${ }^{140}$ Some fortifications needed repairs, extensions, or new separate structures. Beginning in 1766, the colonial administration allotted 100,000 pesos a year from the situado for the fortification projects. ${ }^{141}$ Most fortification constructions began in the late 1760s and continued for the several decades, with many finishing under Coronel Miguel de Muesas' governorship. The construction of the Forteleza de San Juan began in 1533 and finished in 1782, first beginning as a small tower and then evolving into the governor's palace. The well-known San Felipe del Morro, finished in 1584, received new walls for larger artillery, a warehouse, and a cistern for troop use and fires, especially if the city experienced a long siege. ${ }^{142}$ Castillo de San Cristóbal began as a small fort with a few cannons, cisterns, and an arsenal. In 1766, Coronel Tomás O’Daly engineered both San Felipe del Morro and Castillo de San Cristóbal, which took several years to finish because of hurricane damage and other setbacks. ${ }^{143}$ Castillo de San Cristóbal was completed in 1771 and San Felipe del Morro followed in 1776. Governor Muesas finalized other defenses, including San Juan's city walls, the Plaza Militar, and

${ }^{140}$ Ibid, 119.

${ }^{141}$ Bibiano Torres Ramírez, La Isla de Puerto Rico (1765-1800) (San Juan: Instituto de Cultura Puertorriqueña, 1968), 229; Ortiz, Eighteenth-Century Reforms in the Caribbean, 133.

${ }^{142}$ Ortiz, Eighteenth-Century Reforms in the Caribbean, 133-35, Torres Ramírez, Alejandro en los Indias, 89.

${ }^{143}$ Ortiz, Eighteenth-Century Reforms in the Caribbean, 133-35. 
Puente de San Antonio, one of the major bridges for islet-main island travel routes. ${ }^{144}$ Because of weather, work force and skilled artisan scarcity, and construction setbacks, the military defenses hindered the civilian development within San Juan. ${ }^{145}$ The colonial administrations' focus on the military and protecting the island meant the existing civilian infrastructure had to support the general population during normal climatic conditions.

The primary revenue to fund the new defenses came from the very source Field Marshal O'Reilly attempted to remove, the situado. The Bourbon military reforms required the situado more than before, partly because of O'Reilly's defensive and militarization plans. The situado increased from the standard 80,000 pesos in 1765 to 100,000 pesos in 1766 . Military costs utilized the extra capital, especially as more defensive construction began. By 1769, the shipment fell short of covering the island's costs by 614 pesos. Again in 1771, the New Spain financial support increased to 150,000 pesos, and again in 1777 to 225,000 pesos, although the island's government only spent 131,802 pesos. O’Reilly's military goals and developments gained more priority in political and economic decisions, further sinking the island into financial dependency on external sources. ${ }^{146}$

Similar to Puerto Rico, Cuba's situado payments rose throughout the second half of the eighteenth century. However, Cuba's economy benefited from the increase from 437,000 pesos in 1750 s to annually averaging 1,485,000 pesos between 1763 and 1769 . Cuban situado payments rose as much as $10,610,785$ pesos in 1783 . The differences in

${ }^{144}$ Ibid, 137, 139, 142.

${ }^{145}$ Ibid, 143-48, 150, 31-32.

146 Torres Ramírez and Bibiano, La Isla de Puerto Rico, 230. 
situado deliveries between Puerto Rico and Cuba explained why Havana's fortifications secured the capital one of the most fortified cities, while San Juan's construction was substantial at most and only hindered economic reforms. ${ }^{147}$

Incoming settlers rarely filled the particular demographic niche recommended by O'Reilly. The island's population rose from 44,883 people in Alejandro O'Reilly's report to 91,845 people in the 1784 census. Over 2,000 deserters hiding and settling on the island boosted demographic growth between 1769 and $1776 .{ }^{148}$ Many military troops stayed in Puerto Rico and settled after finishing their service, or their unit returned to Spain, even though O'Reilly specifically discouraged this. Governor Miguel de Muesas also contributed to the population growth by establishing new towns, such as Bayamón and Manatí. ${ }^{149}$

Initially in 1760 , the Bourbon monarch also sent Iberian and Spanish American prisoners as labor. Some officials and observers concluded that the prisoners and deserters only contributed to the contraband trade or rarely expanded beyond subsistence means. In 1796, the Spanish monarch ceased the penal importation for similar reasons. A 1778 royal decree permitted landowners to utilize non-Hispanic Caribbean labor under the agreement that they would not engage in commerce and give their oath to Spain and the Catholic Church. These immigrants primary included Irish, French, and Italian

\footnotetext{
${ }^{147}$ Johnson, Social Transformation of Eighteenth-Century Cuba, 42.

${ }^{148}$ Chinea, Race and Labor in the Hispanic Caribbean, 48.

${ }^{149}$ Ortiz, Eighteenth-Century Reforms in the Caribbean, 195-96.
} 
workers. ${ }^{150}$ The population continually rose the rest of the century, reaching 163,192 inhabitants in $1802 .{ }^{151}$

Spain's Bourbon monarchy applied reforms to Spanish America to strengthen its colonies' fortifications, centralize colonial governments, and generate sustainable economies beneficial to the empire. In the case of Puerto Rico, Field Marshal Alejandro O'Reilly's visit offered new opportunities, if properly governed, armed, populated, and invested. The Irish inspector envisioned Puerto Rico's economic potential to be a plantation economy, returning goods and profits to royal treasuries. ${ }^{152}$ However, the monarchy's implemented reforms still relied on a Spanish monopoly system, thus restricting the island's commercial abilities. Despite some reforms, Puerto Rico still depended on the situado, annual New Spain's income, especially after O'Reilly's defensive improvements. Self-sustainability and plantation agriculture was unlikely with external funding and economic restrictions. ${ }^{153}$

Demographic migration related directly to economics. Alejandro O'Reilly's economic proposal required new settlement to promote agriculture and industry. However, the colonial application occurred differently. Between 1765 and 1800, population growth occurred through retired military, deserters, and outside penal labor

${ }^{150}$ Chinea, Race and Labor in the Hispanic Caribbean,48, 49, 51.

${ }^{151}$ Pedro Tomás de Córdova, Memorias geográficas, históricas, económicas y estadísticas de la Isla de Puerto Rico. Vol. 3. (San Juan: Instituto de Cultura Puertorriqueña, 1968) 132.

${ }^{152}$ O'Reilly, "Memoria de D. Alejandro O'Reilly," 112-14.

${ }^{153}$ Ortiz, Eighteenth-Century Reforms in the Caribbean,188; Torres Ramirez, La isla de Puerto Rico, 230-31. 
settlement. A royal decree later encouraged some settlement based on O'Reilly's recommendations, although restrictions exempted the population from commerce. ${ }^{154}$ The overall island's population increased substantially, but occurred more gradually within the colony's capital, San Juan.

San Juan's need for public works commenced with the new reforms in 1765. The modified established system altered population sustainability, particularly through demographic growth. ${ }^{155}$ Although San Juan's infrastructure supported the growing population, it made the existing system sensitive to other changing factors. However, the political and economic reforms contained elements to solve basic necessities, but did not do so because of their political and funding in San Juan's military fortifications.

${ }^{154}$ Chinea, Race and Labor in the Hispanic Caribbean, 48-49, 51.

${ }^{155}$ Ibid, 48-49, 51. 


\section{CHAPTER 3: ECOLOGICAL PROBLEMS AND THE SEARCH FOR BASIC NECESSITY STABILITY, 1765-1800.}

Fortifying, militarizing, and protecting the Spanish American colonies from foreign aggression was the Bourbon Reform's primary intention in the late eighteenth century. Although his economic proposals were not as successful, Field Marshal Alejandro O’Reilly's Puerto Rican military improvements accomplished the main intended goals. San Juan's defenses received the majority of funding and infrastructure, hindering potential public works during normal ecological conditions and minimally contributed to the basic necessities required by San Juan's general residents. ${ }^{156}$

Between 1765 and 1797, most public works and municipal concerns were the result of normal use or environmental events. Civilian public works funding remained minimal, while military defenses governed the colonial government and the economy. Local organizations only focused on drinkable water, sanitation, and transportation during severe crises or when existing infrastructure needed attention. Until the economy stabilized and no longer relied primarily on the situado, public works for the general population remained static. ${ }^{157}$

\section{Potable Water}

San Juan's islet location hindered supplying the city with potable water through natural sources. The salty ocean and bay surrounded the city, while the islet lacked rivers

\footnotetext{
${ }^{156}$ Ortiz, Eighteenth-Century Reforms in the Caribbean, 119-55.

${ }^{157}$ Morales Carrión and Teresa Babín, Puerto Rico, 52-53.
} 
or springs. ${ }^{158}$ Water provisions relied on constructed wells and cisterns for 250 years, depending on the housing structure. ${ }^{159}$ The upper status residents more likely lived in houses built of tile roofs and masonry. Rainwater drained from the roof into personal cisterns for domestic use. Lower status population lived in wooden or table-and-beam houses and utilized larger public cisterns and wells. ${ }^{160}$

Other water retrieval methods sent water bearers to major springs and rivers on the main island. The most notable sources for potable water use included the Miraflores spring, Puerto Nuevo, Río Piedras, Palo Seco, and Bayamón Rivers, most surrounding San Juan's bay. Water bearers then transported the water by carts or boats and sold it in public plazas. The Condado area by the Puente de San Antonio, one of two connecting bridges to the main island, also supplied water within walking distance of the city. ${ }^{161}$ Fountains depended on the time period. During his account of Puerto Rico's status during the 1770s, Fryer Agustín Iñigo Abbad y Lissera stated that there were no fountains on the city's islet, only a small well for the marina, and a weak spring around Castillo de San Cristóbal. ${ }^{162}$ Historian Alfonso de Hostos argued three major fountains provided potable water throughout San Juan's history. When the city was established in the sixteenth century, cisterns, wells, and water bearers primarily provided water to the population. At the end of the sixteenth century, local officials constructed one fountain

${ }^{158}$ Matos Rodríguez, Women and Urban Change, 14.

${ }^{159}$ de Hostos, Crecimiento y desarrollo de la ciudad de San Juan, 477.

${ }^{160}$ Abbad y Lasiera, Historia geográfica, 99.

${ }^{161}$ Matos Rodríguez, Women and Urban Change, 90-91.

${ }^{162}$ Abbad y Lasiera, Historia geográfica, 100. 
while working on a local bridge, called Puente de Agua. They also worked on other projects channeling water over the bridge through a canal. The municipal government constructed the Fuente de Aguilar, a fountain that supplied water during drought periods and when cistern level were low. Another fountain, Fuente de Tejar, supplied military personnel with water until it was abandoned in the late sixteenth century because of rising salt content. ${ }^{163}$ Fuente de Miraflores, a fountain located on the inlet island of Miraflores, served the population well into the mid-nineteenth century because of its excellent water state. ${ }^{164}$

During normal climate conditions, water public works primarily involved cabildo approvals for military structures and the royal prison. Water supply appeals in the royal prison began in 1776, when the governor requested that a fine amounting to 300 pesos be applied to constructing a cistern. He stated that the cistern would limit the number of escaped prisoners, especially when sent to obtain water. ${ }^{165}$ During the early 1780 s, the prison warden ordered, on several occasions, provisional water supplies, including two zambullos, a water tank, and buckets for carrying water for prisoner use. ${ }^{166}$ Military developments did contribute to local water provisions within their own structures. In

163 de Hostos, Crecimiento y desarrollo de la ciudad de San Juan, 477-78.

${ }^{164}$ Matos Rodríguez, Women and Urban Change, 91; de Hostos, Crecimiento y desarrollo de la ciudad de San Juan, 479.

165 Actas del Cabildo de San Juan Bautista de Puerto Rico, 1774-1777 (San Juan: Publicación Oficial del Municipio de San Juan, 1966), \#926, 200-201.

${ }^{166}$ Actas del Cabildo de San Juan Bautista de Puerto Rico, 1777-1781 (San Juan: Publicación Oficial del Municipio de San Juan, 1966), \#1117, 103; Actas del Cabildo de San Juan Bautista de Puerto Rico, 1781-1785 (San Juan: Publicación Oficial del Municipio de San Juan, 1966), \#1277, 114-15; \#1293, 129-30. 
1775, cisterns within the Castillo de San Cristóbal received attention for troop use. ${ }^{167}$ When building a commons area in the military plaza, engineers included a community cistern among other military works, such as a new patio, staircases, and new doorways for horse access. ${ }^{168}$

San Juan's streets helped regulate water flows throughout the late eighteenthcentury, but heavy rains quickly degraded them. Shedding water through streets provided residents with a domestic source, meaning no obstructions could inhibit its flows. In 1799, Captain Don Pedro Galiani requested permission to building a henhouse between his house and Don José Costa's house. The cabildo determined that a land survey was required and sent member regidor Don Antonio de Córdova to study the title claim. ${ }^{169}$ In the next meeting, the local administration permitted that Captain Don Pedro Galiani could build the structure within the given titled lines as long as it did not affect the water flow from the house to a nearby well. ${ }^{170}$

\section{Streets and Roads}

San Juan's six narrow streets running north-south, its seven perpendicular streets and other travel routes were essential in the city's defense and connection with the rest of the island. Because of the military importance, renovations were supported and passed administrators' approval. Most improvements occurred to the two major bridges

\footnotetext{
${ }^{167}$ Tomás de Córdova, Memorias geográficas, 41.

${ }^{168}$ Actas del Cabildo de San Juan Bautista de Puerto Rico, 1798-1803 (San Juan: Publicación Oficial del Municipio de San Juan, 1968), \#124, 213.

${ }^{169}$ Ibid, \#72, 105-7.

${ }^{170}$ Ibid, \#73, 107-10.
} 
connecting the islet to the main island called Puente de Martin Peña and Puente de San Antonio, while street pavement eased travel within the capital and to the bridges.

During the eighteenth century San Juan's two major connecting bridges suffered severe damage caused by natural disasters. Typically, the local cabildo acted promptly on the requests given by military personnel or the governor. In 1763, several bridges along the path between Camase and Toa Alta were determined unusable to the public by war lieutenants, who requested the governor's assistance in the matter. The inconvenience caused the local population by the wetland areas to use neighboring bridges that had been deemed passable and easily cart accessible. ${ }^{171}$ The procurador general, Don Francisco de Andino, in 1782 pressed the cabildo to rebuild the Puente de Martín Peña and the town hall after prisoners had damaged the structures. The governor ordered for the prisoners to be disbursed throughout the island to avoid further destruction. ${ }^{172}$ In 1783 , the procurador general reported damage to the Puente de San Antonio caused by some laundresses using the nearby water source to wash clothes. ${ }^{173}$ Andrea de Montes was specifically named by the cabildo, who forced her to pay for the damage. $^{174}$

General repairs and the composition of the streets surrounding and within the capital concerned local and military officials because of the need for ease of travel

${ }^{171}$ Actas del Cabildo de San Juan Bautista de Puerto Rico 1761-1767 (San Juan: Publicación Oficial del Gobierno de la Capital, 1954), \#508, 53.

172 Actas del Cabildo de San Juan Bautista de Puerto Rico, 1781-1785, \#1207, 49-50.

${ }^{173}$ Ibid, \#1273, 110-11.

174 Ibid, \#1274, 111-12. 
through the narrow streets and access to major plazas. Because the Puente de Martin Peña and Puente de San Antonio were important transportation sites, cabildo members quickly worked in 1778 to built paths and streets connecting the routes. Tomás Pizarro was chosen to oversee the project following the governor's orders. ${ }^{175}$ The procurador general complained to the cabildo in 1764 about the newly paved public streets.

Although the task had taken three months to complete, the unsuitable job showed little improvement. ${ }^{176}$ Street paving appeared again in cabildo records in 1797, the procurador general again appealed to the council and the governor to provide funds and conserve and repair the city's streets. He feared, if ignored, the streets' decay would only cost the public more money. However, officials stated they would return back to the issue, but never did for the remaining part of the century. ${ }^{177}$

Street conditions also interested the cabildo through sanitation. The cabildo made several efforts in the late eighteenth century to clean streets, commons, and plaza areas to initiate city public health measures. It also provided waste removal from housing and other sources that may have affected water supply. In many instances, San Juan's street sanitation conditions reappeared in cabildo records. Specifically, cabildo member Don Bernardino de Aponte, and procurador general, Don Miguel Dávila, presented to the town council a proposal to fix a hole on the corners of four different street blocks, requiring lime. The men were concerned that San Juan residents would use the hole as a

\footnotetext{
175 Actas del Cabildo de San Juan Bautista de Puerto Rico, 1777-1781, \#997, 28.

176 Actas del Cabildo de San Juan Bautista de Puerto Rico 1761-1767, \#552, 66-67.

177 Actas del Cabildo de San Juan Bautista de Puerto Rico, 1792-1798 (San Juan: Publicación Oficial del Municipio de San Juan, 1967), \#1799, 247-77.
} 
waste disposal site. Furthermore, the creek located in the area could possibly produce other holes, thus mindful of future waste debris. ${ }^{178}$ Common areas also collected garbage from some farmers' daily activities and other residents. The cabildo received complaints from different local political offices, including the governor himself. ${ }^{179}$ On different occasions, the local council arranged weekly schedules and hired workers to clean the streets using donkeys and other equipment. ${ }^{180}$

Running water through streets also produced health hazards to residents. ${ }^{181}$ Meat slaughterhouse waste typically drained into the ocean. However, a drought in 1784 lowered water flows, preventing long distance waste disposal, which infected nearby wells. ${ }^{182}$ When Regidor Don Bernardin de Aponte and Procurador General Don Miguel Xiorro proposed cleaning streets of filth and debris in 1775, the cabildo concluded the task was particularly important because the street conditions effected construction of a water pipe in the public commons. ${ }^{183}$

\footnotetext{
${ }^{178}$ Actas del Cabildo de San Juan Bautista de Puerto Rico, 1774-1777, \#916, 190-91. 179 Actas del Cabildo de San Juan Bautista de Puerto Rico 1761-1767, \#454, 11; Actas del Cabildo de San Juan Bautista de Puerto Rico, 1767-1771 (San Juan: Publicación Oficial del Gobierno de la Capital, 1965), \#771, 174-75; Actas del Cabildo de San Juan Bautista de Puerto Rico, 1777-1781, \#1102, 116-18.

${ }^{180}$ Actas del Cabildo de San Juan Bautista de Puerto Rico, 1767-1771, \#771, 174-75; Actas del Cabildo de San Juan Bautista de Puerto Rico, 1777-1781, \#1102, 116-18.

${ }^{181}$ Aida R. Caro Costas, El Juicio de residencia a los gobernadores de Puerto Rico en el siglo XVIII (San Juan: Instituto de Cultura Puertorriqueña, 1978), 156.

${ }^{182}$ Actas del Cabildo de San Juan Bautista de Puerto Rico, 1781-1785, \#1322, 156-57.

${ }^{183}$ Actas del Cabildo de San Juan Bautista de Puerto Rico, 1774-1777, \#848, 99-100.
} 


\section{Public Health and Sanitation}

General public health concern outside epidemics were minimal, reflecting the city's attitude towards only responding to public health and works during crisis situations. Some actions were taken to prevent contagions through general sanitation, as well as removal of ill persons to outside the city. The most notable cases were the leper population and other undesirables. Cabildo officials proclaimed in October 1765 that

individuals showing leper syndromic sickness were to be removed from the city walls. ${ }^{184}$ Actual action did not occur until 1767 when Servenrio Jiorro, a San Juan resident, proposed a special neighborhood for the poor and contagious, including leper population, between the Charco de las Brujas, an area outside town, and one of the major connecting bridges. ${ }^{185}$ The cabildo agreed on surveying the suggested area, deciding who applied for removal, and the restriction of other residents from entering the area following its establishment. $^{186}$

Public works and health were not focal objectives during the late eighteenth century, hindering the capital's ability to address general issues, such as sanitation, potable water, and road repair. Fortification concerns dominated political decisions and finances, despite contributing marginally to San Juan's overall population. ${ }^{187}$ During normal climate conditions, the city's local administration paid little attention to growing

${ }^{184}$ Actas del Cabildo de San Juan Bautista de Puerto Rico 1761-1767, \#561, 110-11.

185 Ibid, \#598, 145-46.

${ }^{186}$ Ibid, \#602, 149-50; \#607, 154-155.

${ }^{187}$ Ortiz, Eighteenth-Century Reforms in the Caribbean, 119-55. 
concerns since the existing structure sustained San Juan residents. Yet, environmental tragedies prompted more governmental intervention.

\section{Eighteenth-Century Natural Disasters and San Juan's Responses}

For most of the late eighteenth century, climate change and natural disasters inhibited basic necessities in the capital city. The island's Caribbean location and its geography made Puerto Rico susceptible to major events, such as earthquakes, hurricanes, strong thunderstorms, and droughts. Many natural disasters' outcomes resulted in losses of life, economic commodities, and infrastructure. ${ }^{188}$ Existing infrastructure and sources could no longer serve their functions until repaired or rebuilt after such destruction. During the late eighteenth century, more frequent natural events only exacerbated the colony's current economic conditions and created more public works projects that consumed existing funding.

Three particular types of climatic natural disasters threatened Puerto Rico and the greater Caribbean region: earthquakes, hurricanes, and drought. Although less frequent than hurricanes and droughts, earthquakes also generated considerable damage to infrastructure and trade losses. The only known earthquake during the eighteenth century was in 1787, which damaged residential houses, fortifications, and specifically San Juan's cathedral. ${ }^{189}$ Hurricanes and drought may occur annually, depending on general weather patterns. However, both natural disasters may respond to climate changes

${ }^{188}$ Flinter, An Account of the Present State of the Island of Puerto Rico, 46-52.

189 Tomás de Córdova, Memorias geográficas, históricas, económicas y estadísticas, 53; "Porto Rico, Wednesday, Storm, Articles, Cuprits," Boston Gazette, 24 September $1787,3$. 
influenced by El Niño and La Niña shifts. The late eighteenth century demonstrated a climatic warming period, resulting in a series of El Niño and La Niña weather patterns. As a result, the latter part of the century experienced more hurricanes and droughts, impacting San Juan, Puerto Rico and the Caribbean region. ${ }^{190}$

\section{Short and Long-Term Hurricane Effects}

Hurricanes threatened the Caribbean region between the months of July and October, causing rain and wind damage. The destruction depended on the storm's strength and wind speeds, uprooting trees and crops, destroying houses and buildings, leaving infrastructure and cultivation in destitution, thus crippling commerce and trade. ${ }^{191}$ Different sources noted major hurricanes and their impacts during the late eighteenth century. In the 1766 season, six major hurricanes travelled through the Caribbean region, landing in many French, British, and Spanish colonies. ${ }^{192}$

Some hurricanes struck Puerto Rico, injuring several people and damaging the ayuntamiento house, Puente de Martín Peña, and Puente de San Antonio, the two major bridges connecting the islet to the main island. ${ }^{193}$ The governor requested that each structure be examined by engineers. ${ }^{194}$ Another report stated that the hurricanes also destroyed houses, plantain and cassava crops, and boats, while causing some roads to be

\footnotetext{
${ }^{190}$ Johnson, “El Niño,” 367-68.

${ }^{191}$ Flinter, An Account of the Present State of the Island of Puerto Rico, 50.

192 Johnson, “El Niño,” 370.

193 Actas del Cabildo de San Juan Bautista de Puerto Rico 1761-1767, \#589, 137-38, \#591, 139-40.

${ }^{194}$ Ibid, \#592, 140.
} 
inaccessible. ${ }^{195}$ The destructive 1766 hurricane season's effect continued into 1767.

Following the season, Spanish local governments permitted trade with non-Hispanic ports to buy critically needed supplies. ${ }^{196}$ Later that year, the cabildo discussed the partially destroyed butchery caused by a hurricane in August. ${ }^{197}$ Within a few months, cabildo members' concerns mounted as the storms caused further food and provisional shortages. ${ }^{198}$

In his traveler's account, French botanist André Pierre Ledru recorded stories about the August 22, 1772, hurricane that impacted the entire colony. ${ }^{199}$ Ledru stated that the hurricane lasted for four hours, bringing violence every half an hour. He described the rains, lightning, and earthquake-like experience that left fields flooded, plantations and houses destroyed, and uprooted trees. ${ }^{200}$

Many major hurricanes, particularly in the 1760s and 1770s, forced Spanish Caribbean colonies to find new food sources at prohibited North American British ports. Puerto Rican governors allowed trade during severe emergencies to supplement food shortages and damaged crops, but had to defend the resolution to the monarchy. ${ }^{201}$

${ }^{195}$ Tomás de Córdova, Memorias geográficas, 30.

${ }^{196}$ Johnson, “El Niño,” 371.

${ }^{197}$ Tomás de Córdova, Memorias geográficas, 31; Actas del Cabildo de San Juan Bautista de Puerto Rico 1761-1767, \#246, 180-81.

${ }^{198}$ Actas del Cabildo de San Juan Bautista de Puerto Rico 1761-1767, \#625, 185-86; \#629, 189.

${ }^{199}$ Ledru, Viaje a la isla de Puerto Rico, 124.

${ }^{200}$ Ibid, 124.

${ }^{201}$ Johnson, “El Niño,” 368, 384, 391. 
Several cabildo records addressed the food and provisional supply concerns, such as the 1767 hurricane season. ${ }^{202}$ Plantation destruction particularly signaled food and commodity crises later. In a 1798 cabildo report, member Don José Dávila stated that record floods left many plantations in ruins along with rice, corn, beans, cassava, and other provisional crops. His distress included the remaining flour supply, which he predicted would barely last the year, even after major conservation. The local council members concurred that the governor needed to supply food provisions for the public good. ${ }^{203}$

\section{Droughts and Administrative Water Works Responses}

Droughts occurred often in the late eighteenth century, forcing more local government involvement in potable water supplies. In four different time periods, cabildo members reported low rain or water levels or "la seca", meaning dry spell. ${ }^{204}$ The most inhibiting drought season happened in the mid-1780s, resulting in further natural consequences for San Juan's population. ${ }^{205}$ Drought seasons drove the cabildo and other local administrations to find alternative ways to provide the water resources to

\footnotetext{
${ }^{202}$ Actas del Cabildo de San Juan Bautista de Puerto Rico 1761-1767, \#625, 185-86; \#629, 189.

${ }^{203}$ Actas del Cabildo de San Juan Bautista de Puerto Rico, 1798-1803,\#14, 12-13.

${ }^{204}$ Actas del Cabildo de San Juan Bautista de Puerto Rico 1761-1767, \#540, 91-92; Actas del Cabildo de San Juan Bautista de Puerto Rico, 1777-1781, \#996, 27-28; Actas del Cabildo de San Juan Bautista de Puerto Rico, 1781-1785, \#1309, 143-44; Actas del Cabildo de San Juan Bautista de Puerto Rico, 1798-1803, \#77, 113.

${ }^{205}$ Actas del Cabildo de San Juan Bautista de Puerto Rico, 1781-1785, \#1309, 143-44; \#1318, 151-52; \#1319, 153-54; Actas del Cabildo de San Juan Bautista de Puerto Rico, 1785-1789 (San Juan: Publicacion Oficial del Municipio de San Juan, 1966), \#1366, 6; \#1376, 12-13.
} 
the city. These resources ranged from purifying existing sources to constructing new collection points as well as religious prayers. ${ }^{206}$ As drought seasons repeated throughout the eighteenth century, San Juan's residents requested more intervention, but they never prepared themselves with preventive measures to avoid a future crisis.

Local townspeople complained about the lack of rainfall in 1763, requiring the cabildo to reconstruct the water source at the Condado area by the Puente de San Antonio. ${ }^{207}$ However, cabildo members officially claimed "la seca" in 1765 after discovering muddy water sources. At the time, their solutions entailed removing the mud and providing copper drinking jars to the population. ${ }^{208}$

The 1778 drought season required more intervention that the previous drought situations. Cabildo member Don Tomás Pizarro stated in February that the city needed water, resulting from the "la seca." ${ }^{209}$ He encouraged quick thinking to resolve the issue. The regidor suggested hiring the city's master builder to estimate and build a structure to collect water, but never stated specifically the plans or what type of water supplier. ${ }^{210}$

A little over a month later, several fires erupted throughout the city. Once again, cabildo members demanded a solution to both the water crises and the fires. The local council required more firefighting items because the week's blazes ruined what was

${ }^{206}$ Actas del Cabildo de San Juan Bautista de Puerto Rico 1761-1767, \#540, 91-92; Actas del Cabildo de San Juan Bautista de Puerto Rico, 1781-1785, \#1319, 153-54; Actas del Cabildo de San Juan Bautista de Puerto Rico, 1798-1803, \#77, 113.

${ }^{207}$ Actas del Cabildo de San Juan Bautista de Puerto Rico 1761-1767, \#507, 51-53. ${ }^{208}$ Ibid, \#540, 91-92.

209 Actas del Cabildo de San Juan Bautista de Puerto Rico, 1777-1781, \#996, 27-28. ${ }^{210}$ Ibid, \#996, 27-28. 
available. Many members listed several items, such as shovels and one-hundred baskets, specifically used to carry dirt to the scenes. Water's value during the crisis meant it could not be wasted on the fire efforts. Requests were sent to surrounding towns and districts to supply the necessary items. ${ }^{211}$

The 1784-1785 drought seasons inflicted San Juan's population and encouraged the most political response. In March 1784, the governor sent the cabildo a water shortage report. The local institution responded by having water bearers bring more water to plazas and carefully divide it among the population. ${ }^{212}$ By May, the governor required Don Antonio de Córdova to open a well and possibly build another cistern. ${ }^{213}$ The cabildo decided at the next meeting that the new cistern would be constructed at the militia house, but many members disagreed on the cistern's purpose. Some officials believed the cistern's design, costing 450 pesos, did not improve the situation because of the construction time required. ${ }^{214}$ By 1785 , water concerns led to several appeals for water supply items and new cisterns in convenient locations. ${ }^{215}$ Capital residents presented a proposal to have a Santo Cristo de lo Ponzes religious procession and worship at the Covento de los Padres Predicadores, Dominican Friars, in one of the

\footnotetext{
211 Actas del Cabildo de San Juan Bautista de Puerto Rico, 1777-1781, \#1000, 31-32.

${ }^{212}$ Actas del Cabildo de San Juan Bautista de Puerto Rico, 1781-1785, \#1309, 143-44.

213 Ibid, \#1318, 151-52.

${ }^{214}$ Ibid, 1781-1785, \#1319, 153-54.

215 Actas del Cabildo de San Juan Bautista de Puerto Rico, 1785-1789, \#1370, 8-9; 1376, 12-13.
} 
city's monasteries, hoping divine intervention could provide relief. Regidor Don Antonio de Córdova was appointed the procession's deputy by cabildo members. ${ }^{216}$

Similar religious measures occurred during the 1799 drought season after Governor Ramón de Castro's letter requested to hold public prayer with the crucifix at Santo Cristo de Ponce. His letter stated that the people's livelihoods required water and did not know of a capable, humanly way to resolve the situation, meaning a need for God's relief. The cabildo reacted to the governor's proposal, agreeing that the Divinísimo Señor Cruicificado to the Ponce patronage be placed in a monastery chapel at the Iglesia del Covento de los the Reverendos Padres Franciscanos that following Sunday. ${ }^{217}$ The next cabildo meeting determined the procession and celebration an initial success, but its consumed funds resulted in payment disagreements between local officials and the Reverendos Padres Predicadores. ${ }^{218}$

\section{Disease: Ecological Results and Impacts}

Drought conditions impacted potable water and other supplies, while also changing the island's environment. The tropical climate supported several diseases known to increase at specific times of the year. Unusual climate changes sometimes encouraged further pathogen spread throughout the population. The mid-1780s drought was also a contagious time. In 1786, yellow fever spread throughout San Juan's population. The attorney general informed the cabildo that several people expulsed

\footnotetext{
${ }^{216}$ Ibid, \#1366, 6.

${ }^{217}$ Actas del Cabildo de San Juan Bautista de Puerto Rico, 1798-1803, \#77, 113-14. ${ }^{218}$ Ibid, 1798-1803, \#78, 114-16;\#79, 116-17.
} 
"black vomit.",219 Many of the ill came from a frigate anchored at the port, and possibly transmitted the disease through fleeing stowaways. He requested that the city act accordingly to remove the threat and prevent further spread. ${ }^{220}$

Unknown until the twentieth century, "black vomit," more commonly known as yellow fever, was not contagious between people, but transmitted by female mosquitoes called Aedes aegypti. When biting an infected subject, the mosquito received the disease and digested it. The disease then moved to the salivary glands to be transmitted once again. The next subject bitten then received the disease when the insect used her saliva to absorb the subject's blood. It can only do so every three days. The disease survived as long as the mosquitoes lived, which was until the late fall season. ${ }^{221}$

In humans, the disease was usually fatal. It first caused chills and head, limbs, and back ache. The inflicted person's temperature rose and he/she rarely urinated. When the fever lowered, it appeared as though the patient possibly recovered from the pathogen, but the high temperature soon resurfaced. The inflicted person looked yellow, vomiting black blood, leading to hemorrhages. The last stages before death included a rapid pulse and brown tongue. ${ }^{222}$

The cabildo and Governor Field Marshal Don Juan Andrés Daban y Busterino attended a meeting on October 2, 1786, to address the yellow fever outbreak and mortality rates. Accounts suggested that seasonal diseases had decreased throughout the

${ }^{219}$ Actas del Cabildo de San Juan Bautista de Puerto Rico, 1785-1789, \#1432, 58-59. ${ }^{220}$ Ibid, \#1432, 58-59.

${ }^{221}$ Powell, Bring Out Your Dead, vii-viii. 222 Ibid, viii. 
last weeks in August, but then ten people appeared in the hospital experiencing "black vomit." ${ }^{223}$ The cabildo received more questions than answers to why the epidemic occurred, mainly relating it to the frigate. According to a city doctor, Doctor Don Tomás Prieto, five patients had died before receiving any medication, including a city widow and three Catalans. ${ }^{224}$ Many attendants at the October 2, 1786, meeting decided on how to contain the epidemic. Provisions for Hospital Real concerned some members, especially as prevention actions meant separating infected patients from other ill. People examining the sick or dead and some shelters received funds, producing major expenses for the city. The cabildo and other administrators gave an edict for residents to vent their houses and start fires to disinfect furniture and other items. ${ }^{225}$ Cabildo records do not indicant the morbidity or mortality from this particular epidemic or how long it occurred in the population.

San Juan, Puerto Rico's location exposed the settlement to many environmental events, more so during the late eighteenth century with climatic warming. ${ }^{226}$ Although an earthquake contributed to Puerto Rico's natural disasters, hurricanes and droughts were the most influential ecological factors, particularly because they forced local officials to address heightened water issues. With increased ecological changes, diseases became more prevalent, further disrupting politics, population, and the economy. Most natural disasters also required the colonial government to react differently compared to normal

${ }^{223}$ Actas del Cabildo de San Juan Bautista de Puerto Rico, 1785-1789, \#1433, 59-62. ${ }^{224}$ Ibid, \#1433, 59-62.

${ }^{225}$ Ibid, \#1433, 59-62.

${ }^{226}$ Johnson, “El Niño,” 378. 
climate circumstances. Public works technically solved the situations that affected the population. However, colonial and local officials rarely acted to prevent a crisis.

Because the changing established system altered by Field Marshall Alejandro O'Reilly's proposals, new instability occurred in the existing infrastructure for population basic provisions. The stress was more apparent during crisis periods than normal climatic conditions when strained infrastructure was exacerbated by unusual ecological events. By the end of the eighteenth century, San Juan's administration contained little ability to address the issues through public works, if they wished to do so. Political attention applied strictly to military defense. Economic stability relied on external funds and a dependent operation. Demographic growth placed pressure on the existing city structures for basic survival. Lastly, the eighteenth century environment was harsher than previous time periods. Public works and health awareness were required to safeguard and support San Juan's population. By the end of the eighteenth century, the required factors to make public works and actions possible in the destabilizing system did not exist. 


\section{CHAPTER 4: THE DECLINE OF SAN JUAN'S POTABLE WATER, PUBLIC HEALTH, AND INFRASTRUCTURE TO 1808}

The political and economic events taking place in San Juan during the 18th century contributed to the island's development as a military post. However, Puerto Rico was still dependent on external funds to function properly. The established government controlled the interrelationship between the political, economic, and social systems as well as the island's demographics, producing a seemingly stable and functioning state. Between 1765 and 1800, the established systems hindered the development of an internal civilian infrastructure that would have been beneficial for the establishment of a sustainable and prosperous colony. The attention to the island's protection only allowed funds to be used for the existing infrastructure during times of environmental crisis such as hurricanes and droughts. The circumstances meant that the island's existing infrastructure, under normal climate conditions, could satisfy the basic needs of the population.

Between 1800 and 1808, Puerto Rico experienced the collapsed of its established system in place since the beginning of its colonization. Political attention both within and outside the island shifted to the general population, primarily as a response to needed changes in economic practices and the promotion of public health awareness. The dependent financial arrangement, the situado, no longer contributed to Puerto Rico's economy because of its unreliability and inadequate funds. The environment as well as the island's population growth did not see significant changes. However, the population increase as well as the climatological changes of prior decades had seriously affected the already decaying public works. For a political and economic system to promote public 
works in San Juan, Puerto Rico, it was necessary for the existing established system come to an end.

\section{San Juan's Growing Crises, 1800-1808}

In 1797, war between Britain and Spain erupted, placing San Juan, Puerto Rico, under serious threat of attack. At the time, Puerto Rico's governor was Don Ramón de Castro, a major military leader known for his campaigns in Spanish Florida and New Spain. Knowing the British intended to capture San Juan, the governor prepared for a siege, requesting 5,000 militia and military soldiers and French privateers. ${ }^{227}$ Needing a labor force, Castro formed an African slave division to rebuild fortifications and to become soldiers when the battle began. ${ }^{228}$ Some military fortifications required attention for Castro's main defensive strategy, particularly the Castillo de San Cristóbal, San Francisco battery, and San Felipe del Morro. ${ }^{229}$ San Juan's women and children left the capital for the main island. Cattle accompanied the fleeing residents as a protective commodity measure, while enough meat and supplies were left for troop use for four months. ${ }^{230}$

British forces invaded and captured Trinidad in February 1797. Soon afterwards, British Commander General Ralph Abercromby's attention turned to San Juan. The capital's improved defenses eluded British intelligence, but Britain's multiethnic military

${ }^{227}$ Morales Carrión and Teresa Babín, Puerto Rico, 54-55.

${ }^{228}$ Torres Ramírez, La Isla de Puerto Rico, 251.

${ }^{229}$ Ibid, 249.

${ }^{230}$ Ibid, 251. 
and navy numbered 14,000 troops. $^{231}$ British ships arrived, quickly capturing the islet's east side and blockaded the port, hoping to siege the population into surrender. Governor Castro anticipated this, focusing many troops on his first defensive line. The result nearly led to the British obliteration after counterattacks from Castro's armed forces from surrounding towns and San Juan's fortifications. The local militia and military troops drove Britain's invasion forces to retreat in May $1797 .^{232}$

San Juan celebrated its victory after the British retreated. The residents had much to rejoice, since the siege damage was not substantial. The Puente de San Antonio and the Castillo de San Geromino received the most destruction. ${ }^{233}$ Indirectly connected to the Puente de San Antonio, the siege promoted new water works for its nearby water source. Regidor Tomás Pizarro reported to the cabildo following the British's retreat that the water source was dry, like many cisterns. Recognizing the essential water source for port ships and the poor, the cabildo immediately ordered for a new structure to replenish the site. ${ }^{234}$ At the next meeting, commissioned Regidor Pizarro announced that the new fountain would cost 48 pesos and 1 real with an applicable voucher. The local council ordered the voucher to be credited to the Fuente de San Antonio's account. ${ }^{235}$

\footnotetext{
${ }^{231}$ Morales Carrión and Teresa Babín, Puerto Rico, 54; Torres Ramírez, La Isla de Puerto Rico, 252.

${ }^{232}$ Morales Carrión andTeresa Babín, Puerto Rico, 54-55.

${ }^{233}$ Actas del Cabildo de San Juan Bautista de Puerto Rico, 1792-1798, \#1808, 285-87.

${ }^{234}$ Ibid, \#1807, 284-85.

235 Ibid, \#1812, 289-90.
} 
The 1797 British attack on San Juan represented the beginning of several changes. The city successfully avoided surrender and displayed its royal loyalty during severe conflict, encouraging new Spanish imperial attention. ${ }^{236}$ Nonetheless, what followed deconstructed what had sufficiently provided the island for centuries. War and conflict disrupted already unreliable communications, while disease, declining public works, and economic instability led Puerto Rico into critical conditions.

\section{Smallpox and Economic Instability: the Rise of Public Health, 1801-1804}

On January 21,1801, San Juan's procurador general, or consul attorney for the city’s cabildo, notified Puerto Rico's governor, Don Ramón de Castro, concerning fears of a possible smallpox epidemic in nearby towns of Punta de Cataña and Pueblo Viejo. His report requested that the people needed to either stay away from the plaza or be very cautious while selling goods. He also suggested that travelers over the Puente de San Antonio, one of the major bridges to the main island, were to be wary and alert, especially during long distance trips. The cabildo elected its member, Regidor Don José Sánchez de Bautamante, and a scribe to investigate the two settlements. ${ }^{237}$ The next meeting confirmed the outbreak and its distance from the capital. Following quarantine measures, the cabildo established timber medical houses in nearby Condado, located within close proximity for supplies to treat the ill. ${ }^{238}$

\footnotetext{
${ }^{236}$ Morales Carrión and Teresa Babín, Puerto Rico, 54-56.

${ }^{237}$ Actas del Cabildo de San Juan Bautista de Puerto Rico, 1798-1803, \#148, 241-42. ${ }^{238}$ Ibid, \#150, 243-45.
} 
The smallpox infection was not the first in Puerto Rico. Throughout the eighteenth century, the island experienced several outbreaks, including a severe pestilence in $1792 .{ }^{239}$ The 1792 epidemic showed signs that the local administration needed to better focus on public health because of the outbreak's extent. During the episode, first-hand accounts stated that people died in neighborhoods and hospitals, while the governor, Coronel Francisco Tarralbo y Robles, was lazy, showing little compassion or relief to those in urgent need. The governor had provided some charity to the diocese bishop, Juan Alejo de Arizmendi, and established places for medicine, supplies, and aid. ${ }^{240}$ The cabildo recommended adopting the governor's fundamental proposals for the residents' benefit, such as distributing meat on specific days of the week because of low provisions. ${ }^{241}$ The primary financial contribution relied on alms because local administrations feared draining the royal treasury. ${ }^{242}$

The smallpox contagion may appear in two forms: Variola major and Variola minor; Variola major usually killed 25 to 30 percent of its infected population, while Variola minor typically held a minimal mortality. The disease began after a 9 to 12 -day incubation period with stomachaches, fever, and pain. Patients may die from hemorrhaging or live two to five more days when the poxes appeared on the face and other parts of the body. The pox perhaps produced infections from the body's inability to

\footnotetext{
${ }^{239}$ Rigau-Pérez, "The Introduction of Smallpox Vaccine," 398.

${ }^{240}$ Actas del Cabildo de San Juan Bautista de Puerto Rico, 1792-1798, \#1588, 23-27.

${ }^{241}$ Ibid, \#1584, 16-17.

242 Ibid, \#1589, 27-29.
} 
protect itself, or dry and leave scars. The dried pox possibly landed on clothing or other materials, and contributed to disease transference, much like air transmission. ${ }^{243}$

During the 1800s outbreak, cabildo and other local governments contained the disease, acting for "the public benefit and the expenditures of its own funds" (“...que parezca más conveniente en beneficio publico y los gastos que ocurren del fondo de propios.”), a quite different attitude in comparison to the 1792 outbreak. ${ }^{244}$ By December 1801, the cabildo appointed a sanitation institution from Spain to prevent further public health threats. ${ }^{245}$ An 1802 decree was sent to the Junta de Sanidad, a Spanish public health and sanitation commission. ${ }^{246}$

The Junta de Sanidad's new members arrived in early 1803, presenting proposals to help the public's wellbeing, including funds for food, medicine, and other expenditures. Public health concerns included African importations, suggesting taxing the trade for public health revenue. Common beliefs concluded that Africans' humor imbalances made them disease carriers, relating to the time's medical knowledge that the

${ }^{243}$ John Aberth, The First Horseman: Disease in Human History (Upper Saddle River: Pearson, 2007), 48-49; For further information about smallpox in Latin American and the Caribbean please reference Noble David Cook, Born to Die: Disease and New World Conquest, 1492-1650 (Cambridge: Cambridge Unversity Press, 1998) and Noble David Cook and W. George Lovell, "Secret Judgements of God:" Old World Disease in Colonial Spanish America (Norman: University of Oklahoma Press, 1992).

${ }^{244}$ Actas del Cabildo de San Juan Bautista de Puerto Rico, 1798-1803, \#151, 245; Actas del Cabildo de San Juan Bautista de Puerto Rico, 1792-1798, \#1584, 16-17; \#1588, 23 27.

${ }^{245}$ Actas del Cabildo de San Juan Bautista de Puerto Rico, 1798-1803, \#188, 304.

${ }^{246}$ Ibid, \#245, 396-99. 
four balanced humors governed a person's health. ${ }^{247}$ The island's climate and other conditions bred diseases, resulting in epidemics. The Junta de Sanidad proclaimed funds provided for both the wealthy and poor. However, the cabildo stated that financial support seemed unlikely. ${ }^{248}$

The economic situation in San Juan, Puerto Rico, slowly declined over the last several decades of the late eighteenth and early nineteenth centuries. Conflict and war within the Caribbean disrupted communications between the colony, Spain, and other parts of the empire. New Spain's charge to send royal money, the situado, became less frequent and incomplete. New Spain's mines produced the royal funds sent as the situado to pay Caribbean military personnel and fortification constructions. The system hindered Puerto Rico from forming a self-sustaining colony through agriculture and commerce, although the island's purpose no longer served as just a military outpost. The small revenue produced through trade and taxation fell short of the Bourbon Reform's expected goals, set after Field Marshal Alejandro O'Reilly's economic report in $1765 .{ }^{249}$

The situado's total amount waivered throughout the 1790s and early 1800s. The allotted situado amounted to over 487,000 pesos depending on the year. ${ }^{250}$ In 1789 , it contained 384,260 pesos, 2 reales, and 23 maravedíes, but it decreased to 183,579 pesos

${ }^{247}$ Actas del Cabildo de San Juan Bautista de Puerto Rico, 1798-1803, \#245, 396-99; Rebecca J. Tannenbaum, The Healer's Calling: Women and Medicine in Early New England (Ithaca: Cornell University Press, 2002), 4-5.

${ }^{248}$ Actas del Cabildo de San Juan Bautista de Puerto Rico, 1798-1803, \#245, 396-99.

${ }^{249}$ Morales Carrión and Teresa Babín, Puerto Rico, 52-53.

${ }^{250}$ Tomás de Córdova, Memorias geográficas, 42. 
in $1792 .{ }^{251}$ New Spain sent 209,600 pesos in 1798 after the 1797 British attack. ${ }^{252}$ In 1803 , the situado rose to 334,000 pesos, but still arrived late. ${ }^{253}$ No situado arrived in the beginning of Mariscal Don Toribio de Montes' governorship from 1804 through $1807 .^{254}$ New Spain's debt to several Spanish Caribbean colonies quickly grew with each year, amounting to $14,144,721$ pesos by $1807 .{ }^{255}$ The inconsistent amounts and missing arrivals meant Puerto Rico relied on what remained in the royal treasury, which quickly diminished throughout the nineteenth century's first decade. The financial shortages created misery for government officials, especially with new expenses. ${ }^{256}$

Despite the unavailable financial support, the Junta de Sanidad's establishment signaled a new political objective through public health. Soon after the smallpox epidemic and the institution's arrival on the island, the Spanish monarch, Charles IV, and his advisors gained interest in English Doctor Edward Jenner's cowpox vaccination. In 1798, Jenner observed and published that milkmaids who contracted cowpox developed immunity to smallpox. Cowpox mortality was less frequent, and its use as a vaccine was more widely accepted than previous inoculation methods. ${ }^{257}$

${ }^{251}$ Tomás de Córdova, Memorias geográficas, 59, 62.

${ }^{252}$ Ibid, 124.

${ }^{253}$ Ibid, 146.

${ }^{254}$ Ibid, 153.

${ }^{255}$ Christon I. Archer, "Bourbon Finances and Military Policy in New Spain, 17521812," The Americas 37, no. 3 (January 1981): 337-38.

${ }^{256}$ Tomás de Córdova, Memorias geográficas, 134.

${ }^{257}$ William H. McNeil, Plagues and People (New York: Anchor Book, 1976), 257-58. 
Because the smallpox vaccine demonstrated effective protection, the Spanish colonial government decided to form the Royal Philanthropic Expedition headed by botanist, Doctor Francisco Xavier de Balmis. The expedition's objective required vaccinating those living in the Spanish colonies to prevent future smallpox infections. Colonies would then continue the inoculation process by keeping the vaccine's cowpox pus fresh through constant transmission to susceptible populations. ${ }^{258}$

The Royal Philanthropic Expedition stopped at several Spanish settlements while crossing the Atlantic Ocean. The stops required obtaining new children to inoculate and keep the cowpox pus and vaccine fresh during the voyage. The expedition arrived in February 1804 at its first major Spanish American colony, Puerto Rico. The smallpox epidemic continued at the time, but the general population restricted the infected to quarantine hut outside the capital. ${ }^{259}$

To Doctor Francisco Xavier de Balmis' surprise, a vaccination effort had already begun. Started by local doctor and military surgeon, Doctor Don Francisco Oller, the existing vaccination arrived from Saint Thomas while inoculating British troops in 1801

${ }^{258}$ Rigau-Pérez, "The Introduction of Smallpox Vaccine," 393-94;

Rigau-Pérez's article illustrates the struggles and conflict between Puerto Rico and the smallpox vaccination commission in 1804. For further information about the expedition: José G. Rigau-Pérez "The Introduction of Smallpox Vaccine in 1803 and the Adoption of Immunization as a Government Function in Puerto Rico." Hispanic American Historical Review 69, no. 3 (Aug., 1989): 393-423 and Magda Gómez de Cruz, "Smallpox Vaccination, the Establishment of Vaccination Boards, and State Formation in Venezuela and Cuba in the Nineteenth Century" (Miami, FL: Florida International University, 2008).

${ }^{259}$ Rigau-Pérez, "The Introduction of Smallpox Vaccine,” 394, 398. 
and 1802. ${ }^{260}$ This was not Doctor Don Francisco Oller's first attempt in using a smallpox vaccine to alleviate the contagion. During the 1792 smallpox outbreak, Oller applied to the governor and cabildo to vaccinate and assist patients. ${ }^{261}$

At first, Doctor Francisco Xavier de Balmis did not consider the previous immunizations an issue, but then accused Oller of malpractice. The expedition leader demanded all previous inoculated population to be revaccinated. ${ }^{262}$ Xavier de Balmis forced the cabildo and the local administrations to conduct a census to determine who had not received the "proper" vaccine. ${ }^{263}$ The revaccination dispute illustrated the Royal Philanthropic Expedition's shortcomings, such as medical authority, handling previously introduced immunizations, and colonial financial expectations to the expedition. The expedition adjusted to prevent such conflict in other colonies following the Puerto Rican experience. $^{264}$

The smallpox epidemic and vaccine expedition demonstrated new political involvement and the pending economic crisis in Puerto Rico. The Junta de Sanidad and the Royal Philanthropic Expedition signaled that the colonial administration had partly changed its demographic view. The expedition was provided to both military personnel

${ }^{260}$ Ibid, 398-401.

261 Actas del Cabildo de San Juan Bautista de Puerto Rico, 1792-1798, \#1588, 23-27; \#1589, 27-29.

${ }^{262}$ Rigau-Pérez, “The Introduction of Smallpox Vaccine,” 402-4.

263 Rigau-Pérez, "The Introduction of Smallpox Vaccine," 408; Actas del Cabildo de San Juan Bautista de Puerto Rico, 1803-1809 (San Juan: Publicación Oficial del Municipio de San Juan, 1970), \#66, 93-34; \#70, 97-98; \#71, 99-100.

${ }^{264}$ Rigau-Pérez, "The Introduction of Smallpox Vaccine," 415-16, 421-23. 
and the general population, highlighting new attention to public well being. The smallpox vaccine also required the local administration to take part in this shifting outlook by preserving the cowpox pus and propagating it throughout the capital and the island. San Juan's cabildo continued to census the residents vaccinated and not vaccinated within the city, establishing a plan that required placing cards on doors and hanging posters. ${ }^{265}$ Unlike the late eighteenth century, the political focus shifted to a wider, general population through public health measures.

The economic consequences from the smallpox expedition foreshadowed Puerto Rico's financial collapse. Relatively unknown to the colony, the expedition required that the hosting colony provide funding, supplies, and other goods. The expenses included housing, expedition, children and their guardians, salaries, and other basic necessities. Governor Don Ramón de Castro’s royal report covered many of the expedition’s costs, amounting to 2,712 pesos, most of which was paid by Puerto Rico's royal treasury and local municipal accounts. The expedition also meant constant inoculation propagation throughout Puerto Rico, meaning new expenses. ${ }^{266}$ The smallpox vaccine expedition contributed to the declining economy already suffering from lacking situado shipments and ruined public works projects.

265 Actas del Cabildo de San Juan Bautista de Puerto Rico, 1803-1809, \#72, 100-2; \#74, 102-4; \#79, 109-10.

${ }^{266}$ Rigau-Pérez, "The Introduction of Smallpox Vaccine," 415-18; Actas del Cabildo de San Juan Bautista de Puerto Rico, 1803-1809, \#80, 110-13; \#83, 117-19. 


\section{Decaying Infrastructure and Changing Political Agendas, 1804-1808}

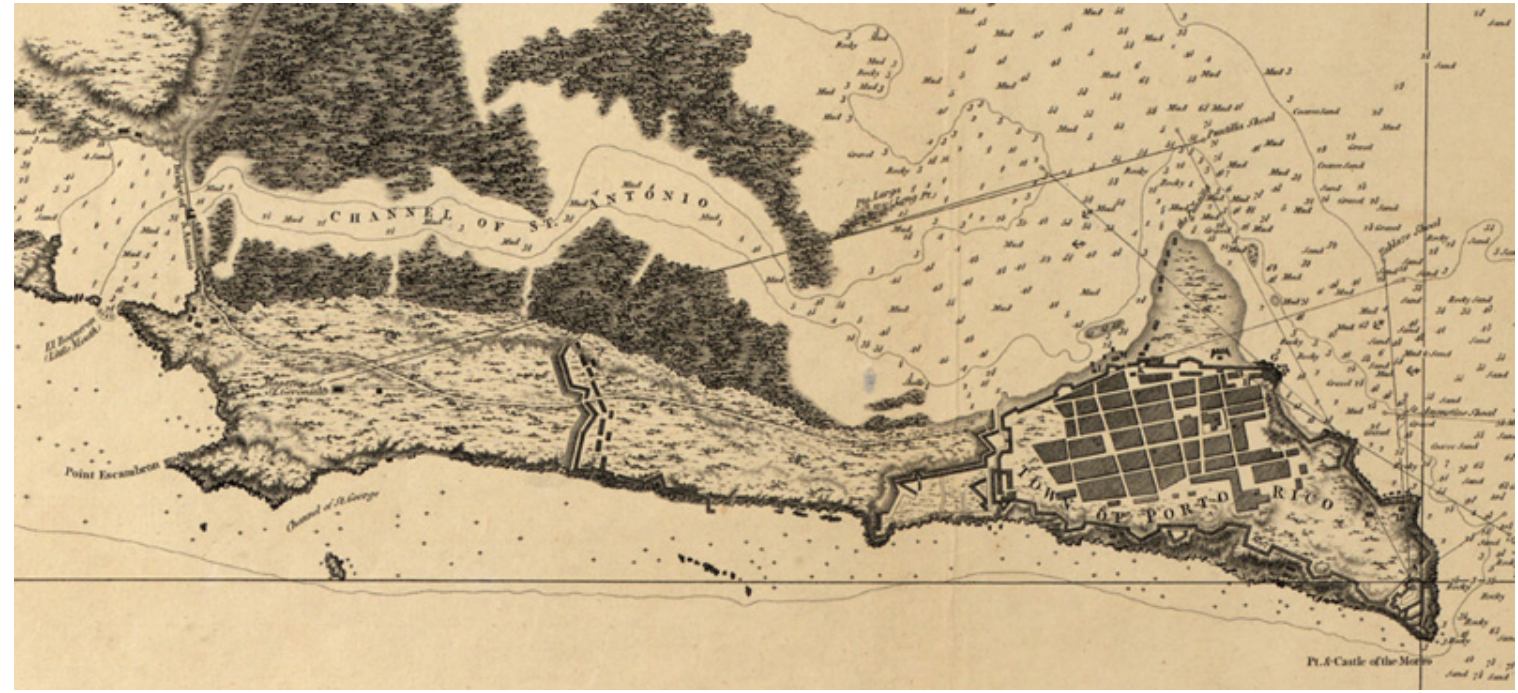

Part of "Geometrical Plan of the Principal Harbour in the Island of Porto Rico" by Cosme Damián de Churruca y Elorza, Library of Congress, $1805 .{ }^{267}$

The political focus shifted to the general population when applying public health measures, but construction remained a military matter. Because the military relied on the situado, defense absorbed most of the funding available. ${ }^{268}$ Work on La Puntilla, a fortification in San Juan, began in January 1805. Twenty prisoners comprised the workforce under the direction of Foreman Ramón Valero of the Regimiento de Infantería to fill a field known as a public health threat. The workers would be paid one or two reales each from the cabildo's own funds. ${ }^{269}$

${ }^{267}$ Churruca y Elorza, Cosme Damián de. "Geometrical Plan of the Principal Harbour in the Island of Porto Rico.” American Memory. Library of Congress. (Washington D.C.: Library of Congress, 1805).

268 Tomás de Córdova, Memorias geográficas, 124, 134, 146, 153.

269 Actas del Cabildo de San Juan Bautista de Puerto Rico, 1803-1809, \#91, 131; \#92, 132-34. 
By March 1805, flooding damaged La Puntilla work filling site and required building a level embankment. The cabildo considered the costs for the altered plans, striving for good work quality more than financial burdens. ${ }^{270}$ In May 1805, the cabildo regarded La Puntilla's work important, although mentioning the impacts to funds. ${ }^{271}$ The next month, the Junta Municipal, presented its own costs in La Puntilla embankment project, reminding the governor of the current economic decline. ${ }^{272}$ That following September 1805, a hurricane struck the island, causing considerable number of deaths and damage to churches, foodstuffs, industry, and houses. Several river banks overflowed and drowned cattle herds. ${ }^{273}$

La Puntilla was one of several beginning construction works in San Juan between 1805 and 1808. Cabildo debates considered establishing a new cemetery, but the idea was quickly pushed aside after budgeting the city's current income. ${ }^{274}$ In 1803 , new prison construction commenced, including a new chapel, two cisterns and wells, and other essentials. The prison's personal account supplied the required income. The cabildo stated the project demonstrated their focus on helping less fortunate residents and administrating better justice. ${ }^{275}$

\footnotetext{
${ }^{270}$ Ibid, \#100, 147-49.

${ }^{271}$ Ibid, \#104, 152-54.

${ }^{272}$ Ibid, \#108, 158-60.

273 Tomás de Córdova, Memorias geográficas, 153.

${ }^{274}$ Actas del Cabildo de San Juan Bautista de Puerto Rico, 1803-1809, \#98, 143-45; \#\#101, 149-50.

275 Ibid, \#11, 16-17.
} 
The new prison project included attention to public health and water. In March 1803, the prison's cisterns were dry, requiring new water sources. The alcalde ordinario, the local magistrate, stated that quick responses were needed for prisoners' welfare. ${ }^{276}$ By 1806, the prison contained new concerns, such as prisoner drinking water and the commons' waste conditions. Some people requested immediate attention for the prisoners' health by the local cabildo. ${ }^{277}$

Besides the La Puntilla project, street composition and potable water repairs accounted as major public works projects during the first years of the nineteenth century. In 1803 , the ayuntamiento sent a letter to the cabildo requesting the street repairs due to damage caused by heavy rains. ${ }^{278}$ By 1806 , the streets lay in ruin, forcing the governor and the auditor of war to press the cabildo to rebuild them. The local council responded that the royal treasury was short on funds and the Real Hacienda, the financial account institution, had established a paving street tax, amounting to 2,000 pesos. Cabildo member Don Manuel Power notified the governor and calculated the costs. ${ }^{279}$ Because of the streets conditions, the project required 200 toneladas of stone, lime, brick, mud, and water. The cabildo ordered posters and notices to advertise materials wanted. ${ }^{280}$ With the Junta de Sanidad's formation, public health continued as a prime objective within San Juan, Puerto Rico. To limit disease outbreaks, the Junta de Sanidad

${ }^{276}$ Actas del Cabildo de San Juan Bautista de Puerto Rico, 1798-1803, \#250, 404-6.

${ }^{277}$ Actas del Cabildo de San Juan Bautista de Puerto Rico, 1803-1809, \#181, 294-95.

278 Ibid, \#15, 22-23.

${ }^{279}$ Ibid, \#151, 213-16.

${ }^{280}$ Ibid, \#153, 222-25; \#201, 325-27. 
proposed other efforts that directly affected the city's conditions and water consumption. In 1803, Don Joaquín Cabrera, acting on the governor's behalf, requested that the cabildo address the public health issue regarding garbage in the Fuente de San Antonio, the fountain constructed by the Puente de San Antonio following San Juan's British siege. ${ }^{281}$ Cabrera proclaimed that animals and laundry washers had access to the site, contaminating the water supply. The cabildo responded by sending a scribe and Regidor Don Juan Antonio Mexía, to investigate and suggest remedies. ${ }^{282}$ At the next meeting, Don Juan Antonio Mexía concluded the fountain required cleaning. Some objections followed, stating to wait since the fountain needed full repair. When that point occurred, they would then address the filth. ${ }^{283}$

The Fuente de San Antonio's condition would resurface, but the cabildo reacted slowly throughout the next few years. In 1804, a gubernatorial decree stated the fountain needed to be more public friendly. ${ }^{284}$ By 1806 , the fountain's decaying structure forced the cabildo to act. Damages caused the water to pool and divert elsewhere. Many cabildo members worried about the potable water source and its conservation, appealing for funds to support rebuilding expenses. ${ }^{285}$ In July 1806, the local administration ordered an inspection of the Fuente de San Antonio, especially since the work needed to

\footnotetext{
${ }^{281}$ Actas del Cabildo de San Juan Bautista de Puerto Rico, 1803-1809, \#6, 6-9; Actas del Cabildo de San Juan Bautista de Puerto Rico, 1792-1798, \#1812, 289-90.

${ }^{282}$ Actas del Cabildo de San Juan Bautista de Puerto Rico, 1803-1809, \#6, 6-9.

283 Ibid, \#15, 23-24.

284 Ibid, \#27, 39-41.

285 Ibid, \#153, 222-25.
} 
be completed before possible failed rains and upcoming droughts. Again, local administrations suggested a new preventive awareness of ecological disasters just as in the smallpox outbreaks. This project and the prisoners' water conditions, unlike some other forthcoming works, received the final immediate attention. The cabildo felt the fountain profited the poorer residents despite costing 2,500 pesos. ${ }^{286}$

The several construction projects reached a financial breaking point. At the same time the Fuente de San Antonio failed, cabildo members still waited on street materials to begin construction. ${ }^{287}$ The cabildo proclaimed in June 1807 that street composition could no longer proceed because of missing materials, mainly the 200 toneladas of stone required. Costs estimates for stones was too much for the remaining funds. ${ }^{288}$ Part of the financial stress also existed from the La Puntilla embankment project. In 1807, the Junta Municipal presented testimony to pay the project's prisoner workers. Starting in June 1805 , the back pay amounted to 10,000 pesos. Correspondence immediately followed between the different municipal offices on how to proceed. ${ }^{289}$

The economic and public work crises needed funding and pressed the local political governments for immediate action. To add to the concerns, the Junta de Sanidad announced in January 1807 that neighboring islands, Santa Cruz and Saint Thomas, were

${ }^{286}$ Ibid, \#161, 261-65; \#165, 267-270. In the cabildo record \#165, they state it is the Puente de San Antonio requiring 2500 pesos. I think this is a transcription error since both \#161 and \#165 proclaim fortification mason builder, Don Luis Huertas, would inspect and rebuild the structure. It also might mean "Puente de San Antonio" because the fountain's location by the main bridge.

${ }^{287}$ Ibid, \#154, 225-26.

${ }^{288}$ Ibid, \#203, 329-33; \#271, 351.

${ }^{289}$ Ibid, \#202, 327-29; \#209, 336-37. 
rumored to have contagious pathogens. Junta de Sanidad measures required the organization to no longer accept ships traveling from those islands at port until news stated the infectious diseases subsided. ${ }^{290}$ Other boats obliged urgent attention from the Junta de Sanidad to avoid other plague vessels, even blocking some Spanish ships from the port's docks. ${ }^{291}$ In turn, this altered any shipping, thus crippling economic stimulus, between the colony and other Atlantic areas. The contagion ban continued until April 1807 when the governor reestablished the Junta de Sanidad visits. ${ }^{292}$

The economic decline from the lack of situado shipments hindered San Juan's ability to support many public works projects. After decades of exposure and deterioration, the public works reached a point that they required attention. Unfortunately, that point coincided with economic stresses still reliant on a centuries-old financial system. Some public works demanded immediate attention, forcing the cabildo, the governor, and other political organizations to choose which was more pressing.

The major determining factor was the public works' contribution to the general public. La Puntilla's construction, although a military structure, pertained to public health protection. The Fuente de San Antonio supplied potable water, thus receiving the proposed funding and concentration despite years of neglect. Political focal points during the first decade of the nineteenth century concentrated on public health through cleaning and preventing future epidemics either by vaccination or restricting port ships. Each contributed to the economic situation by removing existing royal funds. These

${ }^{290}$ Ibid, \#186, 302-6.

${ }^{291}$ Ibid, \#189, 308-10.

${ }^{292}$ Ibid, \#196, 317-19. 
compounding crises crumbled the established political and economic system developed during the eighteenth century. ${ }^{293}$

As Puerto Rico's royal treasury slowly dwindled, the only way to handle the economic and infrastructure situations mandated a higher, more centralized political power's intervention. In the past, the Spanish monarch represented and acted on behalf of Puerto Rico and its Spanish American colonies. However, that power no longer existed in 1808, as King Charles IV abdicated to his son King Ferdinand VII and Emperor Napoleon Bonaparte invaded Spain, capturing the royal family, collapsing the main political control throughout all Spanish territories.

${ }^{293}$ Morales Carrión and Teresa Babín, Puerto Rico. 


\section{CHAPTER 5: CHALLENGING CONDITIONS DURING SAN JUAN'S CONSTITUTIONAL ADMINISTRATION}

Spanish Loyalty and Opposition to French Control, 1808-1812

The Napoleonic invasion and capture of the Spanish Bourbon monarch decentralized the Spanish Empire, contributing to Puerto Rico's already dire circumstances. Forming representative governments promoted loyalty for the Spanish cause in the king's name, while occupied by the French. The same representative body would lose Spain's colonies for their own independence. Developing political situations allowed for Puerto Rico's new significance as a devote vassal and willing receiver of fleeing royalists. However, these same political problems further exacerbated economic crises, forcing local San Juan administrations to restrict internal infrastructure development.

The Constitution of 1812 promoted new local political focuses that reintroduced public works from their static state. Economic crisis gained growth through new political decisions that removed central power from Puerto Rico's governor. Through these simultaneous changes, Puerto Rico increased its potential in becoming a successfully self-standing colony through a new developing system, although actual advancement remained minimal and short-lived. ${ }^{294}$ The 1808-1814 time period began the building of a new system that slowly developed Puerto Rico into a sufficient, booming colony capable of supplying its growing population the basic essentials for survival.

\section{Political Changes within Spain and its Empire}

\footnotetext{
${ }^{294}$ Morales Carrión and Teresa Babín, Puerto Rico, 86-89.
} 
San Juan, Puerto Rico's cabildo pledged its allegiance to Spain after hearing of King Charles' abdication to his son, Ferdinand VII. The cabildo and governor both stated to Secretary of State, Don Pedro Zeballos, that they would obey King Ferdinand VII's wishes as faithful vassals. The governor chose two cabildo members to act as king subjects and to respond to his decree specifically. ${ }^{295}$ Soon after the abdication, Puerto Rico received two junta representatives from Spain, informing the capital about King Ferdinand VII's detainment following Napoleon Bonaparte's invasion of the Iberian Peninsula. With Napoleon replacing the Spanish Bourbon king with his brother, Joseph I, the two representatives wondered about Puerto Rican loyalty. Quite easily, the population proclaimed King Ferdinand as the only true king. Soon afterwards, a representative from Napoleon's government arrived, requesting the current governor, Don Toribio de Montes, his allegiance to the French emperor. San Juan's residents resisted French occupation so much that de Montes had to protect Napoleon's representative by locking him in a fortification to avoid public stoning. ${ }^{296}$

Spain's new political government, the Junta Suprema Central Gubernativa de España y de las Indias, formed to combat against Napoleon Bonaparte and represented King Ferdinand VII. The political government asked the colonies to respect and obey their authority since they acted on the part of the true Spanish king. ${ }^{297}$ The Junta Suprema also decreed in January 1809 that all Spanish colonies were equal as

${ }^{295}$ Actas del Cabildo de San Juan Bautista de Puerto Rico, 1809-1810 (San Juan: Publicación Oficial del Municipio de San Juan, 1968), \#249, 349-96; \#251, 398-401. ${ }^{296}$ Morales Carrión and Teresa Babín, Puerto Rico, 82-83. ${ }^{297}$ Actas del Cabildo de San Juan Bautista de Puerto Rico, 1809-1810, \#10, 14-16. 
contributing important parts of the empire. The colony's participation allowed Puerto Rico to elect Don Ramón Power y Giralt as their representative in the new representative government. $^{298}$

Prior to Power y Giralt's election, a new governor, Don Salvador Meléndez Bruna, arrived in Puerto Rico. ${ }^{299}$ Power y Giralt's proposed reforms would require the governorship and the intendancy to be separated, especially in light of economic crisis. However, his election was overturned after the Cortes Generales Regencia replaced the Junta Suprema. Power y Giralt's reelection under the new representative royal Cortes still permitted him to push his intended changes. ${ }^{300}$

Shifting political issues directly affected Puerto Rico's population, particularly French immigrants. Because Spanish loyalty and French animosity grew in light of Napoleon's invasion, the Junta Suprema ordered all French immigrants to leave Spanish colonies. ${ }^{301}$ San Juan's cabildo received the order, but faced a conundrum. A previous royal order in October 1804 by the king himself stated that France and Spain were allied to benefit French refugees from Santo Domingo. ${ }^{302}$ Puerto Rico's population increase during the 1790s resulted from the growth of French settlers fleeing Santo Domingo's

\footnotetext{
${ }^{298}$ Morales Carrión and Teresa Babín, Puerto Rico, \#18, 32-35; Actas del Cabildo de San Juan Bautista de Puerto Rico, 1809-1810, \#18, 32-35; \#19, 35-8; \#48, 99-100.

299 Actas del Cabildo de San Juan Bautista de Puerto Rico, 1809-1810, \#25, 49-52; \#26, 52-3.

${ }^{300}$ Morales Carrión and Teresa Babín, Puerto Rico, 84; Actas del Cabildo de San Juan Bautista de Puerto Rico, 1809-1810, \#17, 23-25.

${ }^{301}$ Chinea, Race and Labor in the Hispanic Caribbean, 76.

${ }^{302}$ Actas del Cabildo de San Juan Bautista de Puerto Rico, 1809-1810, \#90, 175-77.
} 
slave revolts. ${ }^{303}$ Many settled in San Juan or Mayagüez, a major town on Puerto Rico’s western coast. ${ }^{304}$ Expulsing the French settlers, specifically from Mayagüez, also required considering their plantations and commercial developments. ${ }^{305}$ Mayagüez did not have a census, and their residents had little French communication skills. San Juan needed to make a resolution, impacting both major French settlements. ${ }^{306}$

After debating and organizing lists of possible deportees, the Puerto Rican local government rarely dismissed any French immigrants from the island. Although the decree limited the number for French settlers between 1808 and 1814, French Caribbean immigration returned in following decades under new political and economic freedoms. ${ }^{307}$ Economic interest also played an important role since the French immigrants actually developed and contributed to commerce.

Puerto Rico's population increased during King Ferdinand's capture. The political instability in Spain opened new independent opportunities in Costa Firme, or the Spanish American mainland. Political independent organizations led by Creoles, American-born Spaniards, increased in Caracas in modern day Venezuela. The Junta Supremas dissolved after suppressing protests since 1808. As the Cortes Generales Regencia formulated as the new Spanish government, Caracas Creoles utilized the

${ }^{303}$ Chinea, Race and Labor in the Hispanic Caribbean, 90; "Negativa al Establecimiento en Puerto Rico de Franceses, 1796," Estado 10, 10, Archivo General de Indias (Portal de Archivos Españoles, 1796).

${ }^{304}$ Chinea, Race and Labor in the Hispanic Caribbean, 90.

${ }^{305}$ Actas del Cabildo de San Juan Bautista de Puerto Rico, 1809-1810, \#90, 175-77.

${ }^{306}$ Ibid, \#91, 177-79.

${ }^{307}$ Chinea, Race and Labor in the Hispanic Caribbean, 76. 
opportunity to denounce the formed juntas and proclaim independence under its own Venezuelan government. They declared their independence, stating that they spoke for the true Spanish King, Junta Conservadora de los Derechos de Fernando VII. ${ }^{308}$ News of the Venezuelan revolution arrived in San Juan in October 1810. Governor Salvador Meléndez provided cabildo testimony, stating other possible colonies could adopt Venezuela's motives. To San Juan's cabildo, Venezuelan Creoles had rejected religion, patriotism, and their Spanish devotion. ${ }^{309}$

Because the island demonstrated loyalty to the Spanish Crown during the 1797 British-San Juan siege, Puerto Rico became a haven for many Spanish loyalists fleeing Venezuela's new political government. The arriving population needed proper care and provisions, especially since the refugees usually arrived without currency or possessions. With Puerto Rico's economic crisis, this only produced more problems than solving current issues. Nevertheless, political changes and instability within the Spanish Empire introduced the island as a new political tool. ${ }^{310}$

\section{Economic and Infrastructure Stagnation}

Very little infrastructure improvements occurred since the king's abdication in 1808. Most cabildo financial reports mentioned the low royal coffers and some loans

\footnotetext{
${ }^{308}$ John Lynch, The Spanish-American Revolutions, 1808-1826 (New York: W. W. Norton, 1973), 194-95.

309 Actas del Cabildo de San Juan Bautista de Puerto Rico, 1810-1812 (San Juan: Publicación Oficial del Municipio de San Juan, 1968), \#5, 5-7.

${ }^{310}$ Morales Carrión and Teresa Babín, Puerto Rico, 87, 91.
} 
from the Real Hacienda. ${ }^{311}$ Governor Salvador Meléndez notified Spain in 1811 that 376,896 pesos had arrived from the situado, reiterating the economic misery felt during times of no shipments. His report also stated that the island lacked basic essentials needed for survival, resulting from the low contributions to the royal treasury. ${ }^{312}$ For several years, military personnel received reduced salaries since the situado had not arrived. The island's garrisons slowly caused difficulties for local officials, especially over their pensions. ${ }^{313}$

By July 1812, the economic crisis reached a breaking point, forcing the Junta de Real Hacienda to address growing costs with several local administrations, including the Catholic Church, commercial ministers, and the ayuntamiento. For three years, the island had only received 150,000 pesos even though 300,000 pesos a year was technically allotted. Defects in different administrative branches produced more economic headaches. Local governments requested general censuses to evaluate the population's incomes and goods in order to increase any possible income. The financial situation rippled to obstruct commerce, while was unable to handle underpaid military personnel during war. ${ }^{314}$

${ }^{311}$ Actas del Cabildo de San Juan Bautista de Puerto Rico, 1810-1812, \#6, 6-9; \#42, 109-11; \#55, 148-51.

312 "Sobre cantidad a que asciende el situado que sobra la isla, 1811," 2, Ultramar 1072, Archivo Histórico Nacional (Portal de Archivos Españoles, 1811).

${ }^{313}$ Actas del Cabildo de San Juan Bautista de Puerto Rico, 1810-1812, \#55, 148-51; \#89, 206-10; Tomás de Córdova, Memorias geográficas, 153.

${ }^{314}$ Actas del Cabildo de San Juan Bautista de Puerto Rico, 1810-1812, \#108, 241-45. General censuses began prior to King Ferdinand's abdication in 1806. The requested censuses studied San Juan's residents income, finances, and mortgages. San Juan's population had already been in decline as shown by the 1804 census. The cabildo already 
In the Junta de Real Hacienda meeting, local officials proposed circulating paper money to alleviate the financial concerns. However, paper money also contained its own problems, such as inflation. The cabildo records stated that the meeting's members agreed to avoid many paper money problems through a safe and positive program. ${ }^{315}$ The cabildo voted on the issue a few days later, agreeing to commence paper money circulation using available resources from Ultramar, a Spanish institution governing oversea matters. ${ }^{316}$ Within a month, the procurador general concurred with the governor over the provincial money worth. The paper money amounted to 80,000 pesos divided between pesos, quarter pesos, and reales for public income. ${ }^{317}$

The paper money's establishment did not mean that public works increased between 1808 and 1812. Governor Salvador Meléndez proclaimed a halt to all public building unless permitted by the alguacial mayor, or the local constable. Many public works projects contributed to the economic crisis, so limiting building conserved some local funds until a firmer economic solution could be found. ${ }^{318}$ Although restricted to specific circumstances, some public works continued or began during this time period,

searched for some revenue through census records prior to the 1812 meeting. See Actas del Cabildo de San Juan Bautista de Puerto Rico, 1803-1809 (San Juan: Publicación Oficial del Municipio de San Juan, 1970), \#146, 204-6 and \#169, 278-79.

${ }^{315}$ Actas del Cabildo de San Juan Bautista de Puerto Rico, 1810-1812, \#108, 241-45.

${ }^{316}$ Ibid, \#109, 245-47.

${ }^{317}$ Ibid, \#114, 258-65.

${ }^{318}$ Actas del Cabildo de San Juan Bautista de Puerto Rico, 1809-1810, \#6, 9-10; \#7, 1011. 
although minimal in costs. The approved works primarily benefitted the growth in public health and medicine, local militia, or general public.

The Junta de Sanidad continued to propagate the smallpox vaccine and protected the island's population from outside contagions. The cabildo relayed information from Spain to the organization, especially when particular ships carried diseases. Some reports from sanitation visits stated that most war ships held good health. Even in the king's absence, the main political powers still provided beneficial health services to promote the greater good. $^{319}$

Other medical improvements began in San Juan with the increase of city medical practices and provision for the Hospital Real, San Juan's royal hospital available to general residents. Many new doctors from the Spanish Armada or arriving on the island requested medical licenses. Before the governor and cabildo allowed new practices, applicants required to provide proper educational identification. ${ }^{320}$ Similar to Doctor Don Francisco Oller, who contributed to the smallpox vaccine in 1804, other doctors acted for appeals for the Hospital Real, caring for the sick and spreading the smallpox vaccine. $^{321}$

319 Actas del Cabildo de San Juan Bautista de Puerto Rico, 1809-1810, \#1, 1-3; \#81, 157-9 Actas del Cabildo de San Juan Bautista de Puerto Rico, 1810-1812, \#8, 11-12; \#45, 117-18.

${ }^{320}$ Actas del Cabildo de San Juan Bautista de Puerto Rico, 1809-1810, \#27, 54-56; \#28, 56-57; \#30, 58-61 Actas del Cabildo de San Juan Bautista de Puerto Rico, 18101812, \#27, 29-43.

${ }^{321}$ Actas del Cabildo de San Juan Bautista de Puerto Rico, 1803-1809, \#259, 412-14; Actas del Cabildo de San Juan Bautista de Puerto Rico, 1810-1812, \#69, 178-79; \#82, 194-96. 
Because the governor restricted public works, only two particular projects started between 1808 and 1812: construction on the Cuartel de Milicia and the Palo Seco House. Both works profited the capital's residents either through military defense habitation or a rest place for travelers. The military officials appealed for a new Cuartel de Milicia, a new infantry militia barracks, since the existing building laid in ruins. ${ }^{322}$ At cabildo meetings, many advocators argued for a new Cuartel de Milicia as military officials searched for a new house either to rent or build to supplement the situation. ${ }^{323}$ Expenses limited the work despite constant reports from masons and officials. ${ }^{324}$ The cabildo claimed that the militia would need to use its own account, although some payments included cabildo funding for materials and labor. ${ }^{325}$ Possibly, the cabildo contributed to the project to limit military distress under reduced salaries restriction.

In March 1810, Pablo Fort, a local resident, proposed to the cabildo a new resting house along the Palo Seco passage since the current residence needed attention. Even though ordered to limit public works projects, the cabildo assigned Regidor Don José María Dávila to the project. He first confirmed the current house status with two masons, and then followed with orders for reconstruction. ${ }^{326}$ A year passed after the first

\footnotetext{
${ }^{322}$ Actas del Cabildo de San Juan Bautista de Puerto Rico, 1803-1809, \#266, 421-23.

${ }^{323}$ Ibid, \#270, 426-28.

${ }^{324}$ Ibid, \#274, 433-35; \#275, 435-7.

325 Actas del Cabildo de San Juan Bautista de Puerto Rico, 1803-1809, \#276, 437-40; Actas del Cabildo de San Juan Bautista de Puerto Rico, 1809-1810, \#4, 6-7.

${ }^{326}$ Ibid, \#73, 141-43; \#86, 168-70.
} 
proposal, and the main house was finished. ${ }^{327}$ However, Pablo Fort felt the house still required other resources, such as taller walls in the cistern and a second house for four inhabitants with a pulperia, or local general store. ${ }^{328}$ The cabildo believed the project was complete, rejecting his residential pulpería appeal. After further pressure, the local administration at least addressed the water tank and cistern, costing local accounts 2,300 pesos. $^{329}$

The future of public works and development in Puerto Rico held some hope with Cortes Generales Regencia representative, Don Ramón Power y Giralt. At his request, the local officials and administrations sent their opinions on the island's current conditions. Many criticisms addressed the existing infrastructure, complaining about roads and bridges hindering communications between populated areas, the need for public education programs, and agricultural and industry reform. Spain's political future soon allowed such grievances to receive attention. ${ }^{330}$

Public works projects were mainly suspended because of political instability, economic crisis, and increased population. The events of 1808-1812 period began the process of forming a new system which would develop Puerto Rico into a significant Spanish colony. New governments formed under the name of the true Spanish king, which attempted to hold the empire together. Venezuelan Creoles took advantage of the weakened central power and declared independence under King Ferdinand VII's name.

${ }^{327}$ Actas del Cabildo de San Juan Bautista de Puerto Rico, 1810-1812, \#24, 35-38.

${ }^{328}$ Ibid, \#27, 39-43; \#46, 46-48.

${ }^{329}$ Ibid, \#30, 49-50; \#31, 52; \#38, 97-102.

${ }^{330}$ Morales Carrión and Teresa Babín, Puerto Rico, 84-86. 
Although Puerto Rico disobeyed expulsions orders, the Caribbean colony accepted loyal Spanish refugees fleeing from political strife in Venezuela. Economic stagnation continued despite political shifts. San Juan's local government officials would turn to themselves to find a temporary solution, which was distributing paper currency and limiting construction to only those appeals repeatedly pressured. ${ }^{331}$

For a time, the temporary economic and political systems survived without a central monarch and economic growth. However, in late 1812, the Cortes Generales Regencia shifted its agendas, forming a new constitutional government. The new political administration affected San Juan's public works as new political focuses turned more towards the public's welfare rather than conserving funds.

\section{The Constitution of 1812 and Public Works Progression, 1812-1814}

In July 1812, the Cortes Generales Regencia proclaimed a new constitution comprised of eleven points addressing commerce, municipalities, and ethnic rights and freedoms. ${ }^{332}$ It expanded political control by establishing a three-voting indirect system based on parishes, districts, and providences. A new local political organization within the cabildo, the Diputación Provincial, exercised control over major affairs, such as taxes, finances, public works, hospitals, and education. This institution removed much of the governor's centralized power, especially as the current governor, Don Salvador

\footnotetext{
${ }^{331}$ Ibid.

${ }^{332}$ Ibid, 87-88.
} 
Meléndez, also lost control of the intendancy, which had been under the governor's control since the Bourbon Reform established the office in the mid-eighteenth century. ${ }^{333}$

Don Alejandro Ramírez received the financial and justice intendant role, quickly altering the failed economic system. ${ }^{334}$ After his arrival in February 1813, Ramírez recognized the need for immediate reform, removing the situado as the island's main financial base and reorganizing the existing funds and accounts. ${ }^{335}$ To begin the new financial process, the new intendant tackled the royal treasury's current state. Many accounts were never closed and balances were rarely audited. ${ }^{336}$ Indirect tax collection practices allowed abuse of funds, while hurting present industries and commerce. During the constitutional government, Ramírez replaced the indirect tax system with direct taxes based on the income and commerce of individual towns. The altered economic system allowed some growth until King Ferdinand VII rejected most reforms, after his return. ${ }^{337}$

With the Constitution of 1812, the cabildo quickly changed to the constitution's political conditions. In September 1812, Diputado Provincial elections provided new liberal members political involvement in each diputados. Each one handled different public issues, such as streets, general works, public health, and hospitals at the local

\footnotetext{
333 Ibid, 89.

${ }^{334}$ Ibid, 88-89.

335 Ibid, 90.

${ }^{336}$ Ibid, 89, 81.

${ }^{337}$ Ibid, 89-90.
} 
level. $^{338}$ These new institutions returned to infrastructure issues planned before the abdication and proposed new concerns previously ignored or overlooked. Their focal point concentrated on public health measures similar to the previous political administrations, but stressed the poor and disadvantaged to improve the wellbeing for many San Juan residents.

In early 1813 , each diputado argued for public works and public health through several issues. The diputados recognized that happiness and wealth depended on the government's role, which had not efficiently provided help in the past. Governor Salvador Meléndez passed several issues to the ayuntamiento and the cabildo, such as cathedral repairs, military service titles, education for orphans, and expanding wards within hospitals for both men and women. ${ }^{339}$ Many suggestions rarely proceeded after the first main meeting or were quickly put aside.

Older proposals prior to the king's abdication were considered again, such as the new cemetery. The diputados considered possible benefits, but like before, were limited by public funds. ${ }^{340}$ According to cabildo records, public works were rarely launched or completed during the constitutional period. However, the projects were in the government's best intentions and demonstrated that funds and services applied to most city residents, unlike previous periods where military conscience dominated advantages.

${ }^{338}$ Actas del Cabildo de San Juan Bautista de Puerto Rico, 1812-1814 (San Juan: Publicacion Oficial de Municipio de San Juan, 1968), \#3, 4-7. 339 Ibid, \#21, 54-61. ${ }^{340}$ Ibid, \#21, 54-61; \#47, 124-32; \#48, 132-4; \#50, 138-41. 
The diputados closely worked with the Catholic Church, first to handle disease and later to improve the local hospitals. In tandem with Bishop Don Juan Alejo de Arizmendi, cabildo regidores distributed the smallpox vaccine so children could be inoculated, especially if parents ignored to do so. ${ }^{341}$ The administration required the Catholic Church to report every three months the number of births, disease cases, and deaths in San Juan. These reports also included the practice and number of priest cures to better understand the city's ailments. ${ }^{342}$ The Church also had to immediately notify the jefe, or political chief, a new office under the diputados, of existing or possible epidemics. It also restricted the amount of local funding for Church-run hospitals, such as the Nuestra Señora de la Concepión in the main plaza and Hospital de Caridad. Under orders, these hospitals were sustained by alms and donations. The new revenues meant more municipal funding would be available for other city projects. ${ }^{343}$

Street conditions also escalated into a returning political issue. However, the diputados primarily concentrated on their cleanliness to avoid pathogens than on their recomposition. New cleaning procedures obliged hired worker, Manuel Padilla, to use carts, cattle, and other supplies to remove wastes from houses and streets on a weekly schedule. ${ }^{344}$ The diputados regarded the work as a public contribution and benefit worth

\footnotetext{
341 “Circular del Obispo Don Juan Alejo de Arizmendi Sobre la Propagación de la Vacuna, 1813," Puerto Rico Collection: Pedro de Angelis, Redactor de la Integridad Nacional (Washington D. C.: Library of Congress, 1813).

${ }^{342}$ Actas del Cabildo de San Juan Bautista de Puerto Rico, 1812-1814, \#62, 176-80.

${ }^{343}$ Ibid, \#63, 180-82; \#64, 183-85.

${ }^{344}$ Ibid, \#26, 73-74; \#28, 78-82; \#35, 98-100; \#44, 119-22.
} 
the expenditures for tools, animals, and salaries. Some members even argued it promoted the island's commerce. ${ }^{345}$

The constitutional local government concentrated on public well being through health measures and addressed older cabildo issues, allowing water to become a major focal point in late 1813. The Fuente de Miraflores gained interest as the diputados handled prison water concerns. The local government argued that the poorer prisoners would profit more from the Fuente de Miraflores. ${ }^{346}$ The governor, intendant, and political chief argued over the expenses that would pay for 4 reales pipes required to direct water from the fountain and provided prisoner consumption. Local officials turned to the ayuntamiento with the diputados to inspect the conditions since they were in charge of all public works needed in the city. ${ }^{347}$

Discussions turned to the fortification works master, Don Luis Huertas, for review. He provided a contract for the construction project, including costs calculation based on annual figures. ${ }^{348}$ He concluded that the "aqueduct" or canal cost 80 pesos and 6 pesos a month thereafter for maintenance ("...la composición de uno de sus acueductos de plomo,..."). ${ }^{349}$ The local officials approved the plan, immediately ordering

\footnotetext{
$\overline{345}$ Ibid, \#28, 78-82; \#37, 101-5.

${ }^{346}$ Ibid, \#55, 156-63; \#57, 165-8.

${ }^{347}$ Ibid, \#68, 191-94.

${ }^{348}$ Ibid, \#70, 198-200.

${ }^{349}$ Ibid, \#75, 219.
} 
construction. To further provide for the poorer prisoners, the local administration restricted ships in port from using the Fuente de Miraflores. ${ }^{350}$

The king's returning colonial administration quickly stopped the proposal plans for the Fuente de Miraflores. In January 1815, cabildo officials, inspected the fountain and found it in a state of decomposition. ${ }^{351}$ The Fuente de Miraflores changes signaled the constitution's end in San Juan and the beginning of new Spanish monarchy attention on Puerto Rico. King Ferdinand VII needed Puerto Rico to fully pledge its loyalty and return its previous orderly basis prior to the abdication. However, the returning monarch took advantage of the drastic changes in economics, demography, and public works to secure Puerto Rico and use it for a greater political purpose.

The formation of a constitution in Spain enabled San Juan public works to become the primary local objective. It was an uncharacteristic jump in recognizing infrastructure improvements and addressing the growing potable water issue. The local diputados within San Juan's governments may have not advanced their proposed ideas, but they consciously recognized problems in public health, sanitation, and provisioning of water, although for a small limited group within the royal prison and the less fortunate. Many public developments occurred in conjunction with the new economic system that would allow Puerto Rico to become a sustainable colony. The separated intendancy rejected situado dependency, turning inward to find economic solutions

${ }^{350}$ Ibid, \#75, 219-20.

351 Actas del Cabildo de San Juan Bautista de Puerto Rico, 1815-1817 (San Juan: Publicación Oficial del Municipio de San Juan, 1968), \#8, 13-19. 
through reorganization and tax collection. ${ }^{352}$ Constitutional changes pressed the further breakdown of previous centuries' systems and stepped towards a new system that would address the potable water issue. Both public well being efforts and economic changes continued with the Spanish Bourbon king's return, but public works, such as potable water, would not be as expansive as it had been between 1812 and 1814 .

Within a six year period, the centuries-old established political, economic, and demographic system declined and gave rise to a new system that provided public works and health to become the focal points of providing necessities to San Juan's population. Monarchial changes to promote vaccination were also adopted by revolutionaries under the belief their actions were for the general population. However, financial difficulty limited public works growth in San Juan, but that same difficulty found new solutions within a short time period by reforming the economic system. Although many of these changes were never adopted by the returning Spanish Monarch, they had already promoted new ways of developing Puerto Rico in a self-sufficient colony able to support its population and contribute to the diminishing empire.

${ }^{352}$ Morales Carrión and Teresa Babín, Puerto Rico, 90. 


\section{CHAPTER 6: PUERTO RICO AND THE RETURN OF MONARCHIAL RULE TO}

1823

Economic Growth and New Political Advantages under King Ferdinand VII, 1814-1823

King Ferdinand VII's return was coupled with reorganized political agendas, economic advancements, and demographic growth. These factors contributed to form a new system that could initiate internal infrastructure growth, including provisioning water to San Juan's population. Turmoil within the empire placed Puerto Rico in a new position that required political attention through economic freedoms and immigration incentives. The new developed system created the essential factors required for addressing San Juan's public works and sanitation. However, that same system contributed to new problems that only exacerbated basic needs within San Juan, leaving public works and infrastructure as the only unaddressed factor by the beginning of the second constitutional period.

\section{Puerto Rico: Counter-Revolutionary Base and a New Growing Plantation Colony}

Victorious against Emperor Napoleon Bonaparte, King Ferdinand VII returned as the Bourbon monarch of Spain and quickly acted against liberalizing political organizations formed since his capture. He dissolved the Diputación Provincial and revoked the Constitution of 1812 in mid-1814 and reestablished absolute rule. With his return and almost immediate political decisions, the Spanish Empire fell into chaos as Costa Firma colonies declared independence under Creole governance. ${ }^{353}$ With upheaval on the main American continent, King Ferdinand VII and his advisors acknowledged a new importance for Puerto Rico and other still-peaceful Caribbean colonies.

${ }^{353}$ Morales Carrión and Teresa Babín, Puerto Rico, 89. 
Demonstrating loyalty in the 1797 siege and during his absence, Ferdinand requested that Puerto Rico be protected from possible revolutionary action. ${ }^{354}$

Economic growth and development became a way to remove Puerto Rican liberal strengths and handle the dire financial crisis. ${ }^{355}$ Ferdinand VII first addressed the issue by asking the ayuntamiento and other returning local administrations for advice and suggestions. Similar to Don Ramón Power y Giralt's request when he was elected as Puerto Rico's representative, the local administrations asked for more freedoms in commerce, trade, agriculture, and industry. ${ }^{356}$ The island had already accepted many faithful royalists from revolutionary colonies, promoting a new way to secure the island's future and support. The refugee loyalists mainly included skilled, agriculturalists accustomed to a complex plantation society. ${ }^{357}$

Ferdinand VII granted appeals, decreeing the Real Cédula de Gracias on August 10, 1815. This decree impacted Puerto Rico's economical and political growth, initiating the island possible success and self-nourishment. The decree's thirty-three articles reformed commerce, shipping, settlement, colonist's rights, and slave importation. Each article stated regulations and benefits, many of which applied to colonist incentives and island settlement rights. Many articles included similar requests given by Field Marshal

\footnotetext{
${ }^{354}$ Ibid, 72-73.

355 Ibid, 93.

356 Ibid, 93.

${ }^{357}$ Francisco Antonio Scarano, "The Jibaro Masquerade and the Subaltern Politics of Creole Identity Formation in Puerto Rico, 1745-1823," American Historical Review 101, no. 5 (December 1996): 1428.
} 
Alejandro O'Reilly when he first promoted economic reform in 1765 , such as encouraging skilled and capital immigration for plantation development. ${ }^{358}$

King Ferdinand VII's intended goal in the Real Cédula de Gracias of 1815 was to make his vassals happy by producing a wealthy colony, while acknowledging their loyalty and services to the Spanish monarchy. ${ }^{359}$ Through this decree, the population received its economic freedoms that had been desired for decades. Ferdinand agreed that the previous economic decrees were not as effective as past kings had hoped, such as Charles III's Bourbon economic reforms. Noticing the need for change, Ferdinand combined several past decrees from other Spanish colonies, such as New Orleans and Trinidad, with additional concessions. These allowances would then produce a successful agricultural colony already containing desired natural resources. ${ }^{360}$

The Real Cédula de Gracias allowed different freedoms to existing Puerto Rican inhabitants and future immigrants. First, it lifted restrictions and opened commerce and shipping between foreign empires and Puerto Rico. The Real Cédula de Gracias included incentives to encourage use of Spanish ships and goods. Spain still benefited under some conditions, such as goods not sold within the Caribbean region being returned to Spain or to the colonies. Spain still regulated trade under required invoices, but the process was

\footnotetext{
${ }^{358}$ Morales Carrión and Teresa Babín, Puerto Rico, 93.

359 "Real cédula de S. M. que contiene el reglamento para la población y fomento del comercio, industria y agricultura de la isla de Puerto Rico," Madrid en la Imprenta Real, Library of Congress (Washington D. C., 1815), 1-1.

360 Ibid, $1-1$.
} 
less demanding. The decree also encouraged ship building and ownership by new settlers with proper titles and local government permission. ${ }^{361}$

The Real Cédula de Gracias' mainly presented rights and incentives for immigration populations. Articles 8 to 15 primarily explained settlement procedures, land holding percentages based on Caucasian and slave migration, and settler's assets after death. Basic regulations requested settlers to be Roman Catholic, claim Spanish allegiance, and obeying colonial and monarch orders. Under these agreements, settlers held the same rights as Spanish citizens. Land grants depended on the number of people immigrating to the island, as well the number of slaves. If settlers stayed on the island for five years, they received all naturalization rights along with their children, but had to serve in the militia. Colonist may leave after five years and could remove assets without charges. Some articles also protected assets after death, especially if without a will, giving the heir choices to stay in the colony and hold the same rights as their previous relatives. $^{362}$

New commerce, civic, slave importation, and travelling rights primarily applied to the incoming immigrants and some Puerto Rican inhabitants. Some articles covered new freedoms on shipping sales taxes and building refineries, previously restricted to promote only Spain's industries. ${ }^{363}$ Settlers and residents must defend the island during war times, but could carry arms in peaceful periods to defer piracy and slave revolts. ${ }^{364}$ With the

\footnotetext{
${ }^{361}$ Ibid, 1-2, 2-1, 2-2, 4-2, 5-2.

${ }^{362}$ Ibid, 2-1, 3-1, 4-1.

${ }^{363}$ Ibid, 4-1, 6-2.

364 Ibid, 4-2.
} 
governor's permission, colonists could travel to Spain and may obtain slaves from other Spanish colonies or neutral countries. ${ }^{365}$

Colonial officials in San Juan, Puerto Rico responded with both relief and concerns. On one hand, Governor Salvador Meléndez and Intendant Alejandro Ramírez recognized the urgent need for economic reform. In royal reports, they stated that the Puerto Rican people had made sacrifices, especially for defense costs and military salaries. ${ }^{366}$ On the other hand, they held several worries about the Real Cédula de Gracias' outcome. The governor and intendant stated the treasury would be short if the king permitted tithes and sale tax exemptions. Puerto Rico's security may weaken if the Spanish monarch allowed foreign ships and nations into its ports. Ramírez and Meléndez preferred returning to Spanish shipping and encouraged a Spanish merchant fleet instead. Both men also discussed the situado shipments, stating the lacking of New Spain income would force Puerto Rico to spend its royal treasury funds on the fortifications and stationed troops. ${ }^{367}$ In the end, Puerto Rican officials complied with the decree's terms despite objections. ${ }^{368}$

\footnotetext{
${ }^{365}$ Ibid, 4-1, 2-1.

366 Alejandro Ramírez and Salvador Meléndez, "Sobre medidas para favorecer la riqueza en Puerto Rico, 1815," 2, Ultramar 1112, Archivo Histórico Nacional (Portal de Archivos Españoles, 1815).

367 Alejandro Ramírez and Salvador Meléndez, "Sobre medidas para favorecer la riqueza en Puerto Rico, 1815," 3, Ultramar 1112, Archivo Histórico Nacional (Portal de Archivos Españoles, 1815).

368 Salvador Meléndez, "Sobre medidas para favorecer la riqueza en Puerto Rico, 1816," 12, Ultramar 1112, Archivo Histórico Nacional (Portal de Archivos Españoles, 1816).
} 
The Real Cédula de Gracias of 1815 effected both Puerto Rico's short and longterm periods. Under the new economic and population conditions, Puerto Rico's economy prospered to finally support itself without external funding. Many incoming settlers provided the skills and knowledge needed for the economic growth. For the long term, the island's demography, culture, and landscape changed drastically, especially allowing infrastructure construction during the 1830s and 1840s.

Before 1823, development and demographic growth recovered the island from its economic collapse. After the Real Cédula de Gracias, domestic legal trade revenue increased in American dollars from $\$ 269,000$ in 1813 to over $\$ 2,103,498$ in 1818 . Trade with non-Hispanic countries, such as France, Britain, and the United States, produced most Puerto Rican income. ${ }^{369}$ Many royalists migrated from rebelling Costa Firme and other Caribbean colonies. Most refugees arrived with few assets and necessitated state assistance, straining Puerto Rican recovery. ${ }^{370}$

Short-term economic growth under the Real Cédula de Gracias coincided with other economic advancements occurring throughout the late 1810s. Don Alejandro Ramírez still remained the intendant after King Ferdinand VII's return. Although the king dissolved his direct tax system, the monarch's new tax reform provided new revenue. All Puerto Ricans paid taxes based on agricultural wealth and income under

\footnotetext{
${ }^{369}$ Morales Carrión and Teresa Babín, Puerto Rico, 69.

${ }^{370}$ Arturo Morales Carrión and María Teresa Babín, Puerto Rico, 77, 91. Little research has studied the short term population growth, especially those from the main Spanish American continent, meaning little knowledge of the people and their initial settlement experiences. See Raquel Rosario Rivera, La real cédula de gracias de 1815 y sus primeros efectos en Puerto Rico (San Juan: Universidad de Puerto Rico, 1995).
} 
Ferdinand's new reforms. Still demanding more income to support the growing refugee population, Ramírez reintroduced several new taxes not enforced for many decades, such as rent and slave taxes. ${ }^{371}$

Intendant Don Alejandro Ramírez's reforms tackled the growing paper money concerns and boasted public financial knowledge. To trust the recovering economy, Ramírez published and circulated the rising royal treasury amounts. This method prevented possible funding abuses as seen in previous administrations and helped the population to be more involved. ${ }^{372}$ Since its distribution in 1812, the amount of circulated paper money was over 350,000 pesos and as feared, provoked inflation and devaluation. To handle the issue, Ramírez adopted the moneda macuquina, or the Venezuelan currency, for both, its benefits to stop paper money exchanges and its increasing presence from Venezuelan migrants. The adoption addressed part of the hard currency concern, but paper still hindered the economy while in circulation. Tax collection and lotteries allowed local financial institutions to slowly remove the circulated paper money. ${ }^{373}$ With most financial changes, the royal treasury multiplied over eight times as compared to early 1800 s finances, but still fell short on supporting the island as Spanish American pirates took advantage of kidnapping, contraband, and war, hindering further commercial growth. ${ }^{374}$

\footnotetext{
${ }^{371}$ Morales Carrión and Teresa Babín, Puerto Rico, 90-91.

${ }^{372}$ Ibid, 91-92.

${ }^{373}$ Ibid, 91-92.

${ }^{374}$ Ibid, 96, 74.
} 
During the king's capture, liberal Creoles in Puerto Rico played a delicate balancing game between supporting the Spanish absolutism or rejecting it all together. They still wanted important changes in politics and economics. ${ }^{375}$ However, many liberals still shared some concerns with other political groups, especially the growing anxiety towards slave revolts and increasing freed population. ${ }^{376}$

Puerto Rican demography changed dramatically within a short period of time. The population shift mainly impacted the liberal population. The constitutional period allowed some liberals more say and action within the government. With the population influx, more people were involved, meaning liberal Creole representation was more limited. Even before the Real Cédula de Gracias, many arriving immigrants included several nationalities from different parts of the world, such as Europe, other Caribbean nations, and Spanish colonies. The Venezuelan royalists specifically improved conservation ideals. $^{377}$ The Real Cédula de Gracias of 1815 increased island immigration, including ethnic groups from German and Italian states, North America, and Britain. In the mist of economic growth and exploding populations, liberals, especially Creole liberals, lost more chances to promote their agendas. ${ }^{378}$ Some immigrants arrived from Haiti, a new country instituted by ex-slaves. Fearing slave revolts forced many

\footnotetext{
375 Scarano, “The Jibaro Masquerade,” 1427.

${ }^{376}$ Ibid, 1426.

${ }^{377}$ Ibid, 1428-29.

${ }^{378}$ Ibid, 1428-29.
} 
Creole liberals to reconsider revolution or rebellion. Under the current political government, they held some protections and support. ${ }^{379}$

\section{Public Work Continuations and Repetitive Shortfalls}

The new economic prosperity, growing political focus, and increasing population each contributed shifting changes in public works. Because the economy was slowly recovering, public funds still hindered construction efforts. With the king's return and the people's interest in mind, San Juan's local administration once again returned to public health concerns. The lower classes and the poor received some pressing improvements. Some construction works included less pressing necessities, such as clock tower, but were still viewed as profitable to San Juan's residents. ${ }^{380}$ A new transitional period began for general construction, although public works were minimal. Most notably, water works were static and only addressed the existing system despite signs of stress.

Soon after the announcement of the Real Cédula de Gracias, Intendant Alejandro Ramírez notified Spain of two significant hurricanes that caused damage within a thirtyday period. The two hurricanes, one on August 30 and the other September 15, 1815, beached several ships and destroyed others. Puerto Rico's expected good harvest was lost, particularly rice and maize. ${ }^{381}$ The events signaled how environmental disasters

${ }^{379}$ Ibid, 1426.

${ }^{380}$ Morales Carrión and Teresa Babín, Puerto Rico, 92-98.

${ }^{381}$ Alejandro Ramírez, "Notificación de daños causados por huracanes, 1815-1816," 56, Ultramar 1967, Archivo Histórico Nacional (Portal de Archivos Españoles, 1815-18). 
could occur at unexpected times, especially as the economic showed promise and internal infrastructure lay in ruin.

Most political organizations between 1800 and 1814 approached public health and preventing contagions as a major benefit to the general population. This mainly started with the 1801-1802 smallpox epidemic and the smallpox vaccine's introduction in 1804 . When the expedition left Puerto Rico, local leaders continued the smallpox vaccine because if the propagation was left fallow, the vaccine would require reintroduction. ${ }^{382}$ Despite efforts by changing political administrations between 1804 and 1814, it was evident that the smallpox vaccine had been lost by 1815 . The restored cabildo, after losing the diputados, understood the consequences, quickly looking for a new vaccine in other colonies, such as Santo Domingo. After discovering the cost to reintroduce the vaccine from another colony, the cabildo turned to San Germán, Cabo Rojo, and other cities of the island for possible continued vaccine commissions from the original mission. Even then, expenses outweighed the allotted funds available. ${ }^{383}$

With the loss of the vaccine, compounded by population influx, Puerto Rico once again experienced a smallpox epidemic. In April 1818, the Junta de Sanidad appealed for a building to house infected residents with at least twenty-five beds and other provisions, funds, and services from the Real Hospital Militar. ${ }^{384}$ By August 1819, the Junta de Sanidad felt there had been no progression against the disease and the upcoming season

${ }^{382}$ Rigau-Pérez, "The Introduction of Smallpox Vaccine ,"416-18.

383 Actas del Cabildo de San Juan Bautista de Puerto Rico, 1815-1817, \#15, 33; \#28, 6465, \#31, 70-71.

384 Actas del Cabildo de San Juan Bautista de Puerto Rico, 1817-1819 (San Juan: Publicación Oficial del Municipio de San Juan, 1977), \#50, 77-79. 
may exacerbate current circumstances. The cabildo organized a commission that obligated people to visit and assist the sick and provide medicines, even in troop barracks. Regidores and alcalde ordinarios were assigned to provide relief and prevent infection, especially when burning clothes and furniture. ${ }^{385}$ The cabildo further appealed to the growing number of boticarios within the city to provide ingredients and recipes for medicine. ${ }^{386}$ Medicine and boticas continued into October 1819, as the Hospital Real aided the poor within a two-month period, costing 46 pesos and $4 \frac{1}{1 / 4}$ reales. ${ }^{387}$

Despite rejecting the constitutional period, the reinstituted cabildo indirectly adopted some focal agendas, particularly addressing the poorer population. Beginning in 1816, the cabildo acted for the less fortunate seen in public, such as peddlers in the plaza and herbalists at the marina. The local administration proposed to the governor to work for the poor and provide needs, especially within the prison. Governor Don Salvador Meléndez agreed, initiating a nineteenth-day proposal on how to maintain the prison. ${ }^{388}$ In 1819 , the prison's poor received new construction works costing 55 pesos and $5 \frac{1}{2}$ reales. ${ }^{389}$ Although not major advancements, the cabildo's actions had officially

${ }^{385}$ Ibid, \#110, 160-62; \#111, 162-63.

${ }^{386}$ Actas del Cabildo de San Juan Bautista de Puerto Rico, 1817-1819, \#110, 160-62; \#111, 162-3; \#116, 170-71 Actas del Cabildo de San Juan Bautista de Puerto Rico, 1820-1821 (San Juan: Publicación Oficial del Municipio de San Juan, 1978), \#6, 10-13.

${ }^{387}$ Actas del Cabildo de San Juan Bautista de Puerto Rico, 1817-1819, \#118, 174-76.

${ }^{388}$ Actas del Cabildo de San Juan Bautista de Puerto Rico, 1815-1817, \#85, 163-65; \#87, 169-170.

${ }^{389}$ Actas del Cabildo de San Juan Bautista de Puerto Rico, 1817-1819, \#116, 170-71. 
abandoned eighteenth-century notions that public applications only applied during an ecological crisis.

During this severe period, the cabildo adopted some constitutional decisions on street cleaning and sanitation. The local administration hired Tadeo Martín to handle street waste following a Junta Municipal agreement. ${ }^{390}$ The governor later required cleaning carts specifically around the slaughterhouses and butcheries. ${ }^{391}$ By 1820 , cabildo records indicated complains that cleaning actions had stopped and the alcalde ordinarios would manage the practice. ${ }^{392}$

General street conditions demonstrated how local officials needed to develop the existing infrastructure. During repairs to the Fuente de San Antonio, cabildo officials also addresses street repair for public use. Manuel Hernáiz received 1,500 pesos for the repairing streets in addition to the request for him to oversee repairs to the Cuartel de Milicias. ${ }^{393}$ Street repair discussion resumed in 1817 when cabildo members voted on the percentage of funds for streets versus funds required for repairing rooms in different government buildings. Street repair became lost in building requests and the need for materials. $^{394}$ Although in early 1818 administrative officials stated they were in ruin, streets improved in 1820 following Governor Gonzalo Arostegui y Herrera's concern

${ }^{390}$ Actas del Cabildo de San Juan Bautista de Puerto Rico, 1815-1817, \#13, 26-28; \#15, 30-33.

${ }^{391}$ Actas del Cabildo de San Juan Bautista de Puerto Rico, 1817-1819, \#16, 20-23.

${ }^{392}$ Actas del Cabildo de San Juan Bautista de Puerto Rico, 1820-1821, \#21, 13-15.

393 Actas del Cabildo de San Juan Bautista de Puerto Rico, 1815-1817, \#66, 128-30.

${ }^{394}$ Actas del Cabildo de San Juan Bautista de Puerto Rico, 1817-1819, \#21, 30-32. 
about streets lights at night. ${ }^{395}$ Despite street and road conditions through San Juan and the remaining parts of the island, the governor requested officials to construct lanterns to light traveling routes in the city. The order also required barracks and barrios to notify houses of night changes and establish a branch to follow the policy. ${ }^{396}$

By 1820 , local administrations actively discussed building a clock tower.

Typically, basic essentials precede other considered-luxurious public works projects, although the project intentional proposal suggested the clock tower would profit the capital's entire population. ${ }^{397}$ The governor's office, the engineer commandant, and the ayuntamiento exchanged opinions on the proposed projects. The cabildo determined that each office and account would need to sign and formalize the structure. ${ }^{398}$ A following cabildo session included tax income, amounting to 16,201 pesos, 5 reales, and 25 maravedíes and other figures for construction. ${ }^{399}$

In comparison, the existing water system showed little additions between 1814 and 1821. The cabildo wanted to rebuild the Fuente de San Antonio and conserve the standing structure. In 1817, the cabildo received a cost approval for piping at the Miraflores spring. The local administration paid the engineer commandant 1,730 pesos

\footnotetext{
395 Actas del Cabildo de San Juan Bautista de Puerto Rico, 1817-1819, \#38, 59-62; Actas del Cabildo de San Juan Bautista de Puerto Rico, 1820-1821, \#15, 25-27.

396 Actas del Cabildo de San Juan Bautista de Puerto Rico, 1820-1821, \#15, 25-27.

397 "Documentos relativa a la instalación del primer reloj publico que tuvo la Capital de Puerto Rico, 1815-1817," Puerto Rico Collection: Pedro de Angelis, Redactor de la Integridad Nacional, (Washington D. C.: Library of Congress, 1815-17).

${ }^{398}$ Actas del Cabildo de San Juan Bautista de Puerto Rico, 1820-1821, \#15, 25-27. ${ }^{399}$ Ibid, \#16, 28-30.
} 
and 2 reales for the work. ${ }^{400}$ In March 1818, the governor ordered 25 pesos from fines to be assigned to the Miraflores spring by regidor building intendant, Don Manuel

Hernaíz. ${ }^{401}$ A year later income shortages forced the building of Fuente de Miraflores to stop. $^{402}$ The cabildo recovered documents to confirm the Fuente de Miraflores construction, its repairs cost and essential materials. ${ }^{403}$

In March 1820, the ayuntamiento received 4,000 pesos specifically for public advantages. The cabildo recommended that the funds apply to the Fuente de Miraflores rebuilding project, although it is not clear if the suggestion was taken. ${ }^{404}$ The Fuente de Miraflores issue caused new concerns as the cabildo actively conserved the water in both the fountain and cisterns. Immediate attention turned to repairs, ordering major mason masters and fortification workers to pay attention to the fountain. Once again, the cabildo requested established costs and calculations. ${ }^{405}$

Between 1814 and 1823, the island experienced many changes in politics, demography, and economics to produce a new system encompassing public wellbeing. Puerto Rico held a new political role, which helped develop a self-supporting, wealthy colony. However, a repeating cycle formed in public works and health measures. The smallpox epidemics and vaccination expedition and conservation movements in the early

${ }^{400}$ Actas del Cabildo de San Juan Bautista de Puerto Rico, 1817-1819, \#16, 20-23.

${ }^{401}$ Ibid, \#44, 69-70.

${ }^{402}$ Ibid, \#113, 164-66.

${ }^{403}$ Ibid, \#114, 166-68.

${ }^{404}$ Actas del Cabildo de San Juan Bautista de Puerto Rico, 1820-1821, \#11, 19-22.

405 Ibid, \#31, 69-73. 
1820 s reflected problems in the 1800 s. San Juan, Puerto Rico, finally contained many required elements for public works and sanitation. As the second constitutional period produced new political stability, public works and infrastructure stood as the only unaddressed factors for island's growth and stability. 


\section{EPILOGUE: PUBLIC HEALTH TRANSFORMATION AND NEW OBSTACLES IN MID-NINETEENTH CENTURY SAN JUAN}

The Development of Puerto Rico's Conservative Colonial Government and the Rise of the Plantation Economy

On January 1, 1820, military forces under Colonel Rafael del Riego revolted in Spain, forcing King Ferdinand VII to accept a second constitutional period. ${ }^{406}$ As before, San Juan officials established a new constitutional ayuntamiento following the prior royal decree of May 1812. Many offices returned, such as the jefe political and the diputados, directing public institutions, such as the prison, public health and education. ${ }^{407}$

Many constitutional achievements were not the same for Creole liberals in Puerto Rico. Unlike the 1812 period, Puerto Rico's society and political interest differed. The island was growing into a complex, plantation society. Immigrating populations loyal to the Spanish monarch hindered their political agendas. Numerous free Africans threatened possible rebellion. King Ferdinand VII's measures prevented Puerto Ricans from revolting by limiting civil rights. ${ }^{408}$

Following the second constitutional period, the political control strengthened counter-revolutionary actions, especially under Don Miguel de la Torre's governorship between 1823 and 1837. On one hand, political stability existed under severe conservative restraints. ${ }^{409}$ On the other hand, it manifested economic growth dependent

\footnotetext{
${ }^{406}$ Morales Carrión and Teresa Babín, Puerto Rico, 100.

407 Actas del Cabildo de San Juan Bautista de Puerto Rico, 1820-1821, \#19, 34-36; \#25, 46-49.

408 Scarano, “The Jibaro Masquerade," 1429.

${ }^{409}$ Morales Carrión and Teresa Babín, Puerto Rico, 101.
} 
on improving infrastructure. Infrastructure advanced Puerto Rico's commerce and communication throughout the island. However, San Juan's population continued to grow, leading to new public health concerns and basic necessities.

Don Miguel de la Torre's governorship was the longest in the island's history. Within his fifteen years as governor, Puerto Rico lived under strict conservative politics, but those same restrictions allowed the island to flourish without political upheaval as seen throughout the early nineteenth century. Although frowned upon by most observers following his time in office, de la Torre considered himself an enlightened despot who tightened many government branches and made public administration more efficient. $\mathrm{He}$ ordered the Junta de Visita, a special security branch in the government, to act as an information source regarding rebellions and liberal ideals. King Ferdinand VII wished to protect Puerto Rico and Spain's other Caribbean assets from the independent influences. Governor de la Torre successfully defended the island's political nature with an iron fist. $^{410}$

With a growing skilled population and a "stable" political machine supported by the Spanish monarchy, Puerto Rico experienced its "Pax Romana."411 The Real Cédula de Gracias' long-term results blossomed in the next two decades as the plantation economy brought income, migration, and infrastructure to the island. Sugar cultivation flourished along the island's coast, particular in the southern region. The location allowed good agricultural conditions and quick access to new expanding ports, such as

\footnotetext{
${ }^{410}$ Ibid, 101.

${ }^{411}$ Ibid, 107.
} 
Ponce and Guayama. Between 1820 and 1896, sugar plantations tripled, producing over 62,000 tons of sugar. Prior to the time frame, the island only produced 17,000 tons. However, the sugar expansion never reached the high success experienced by Cuba during the nineteenth century. Because of the Cuban sugar focus, Puerto Rico struggled even more with labor shortages, high taxes, and horrible commercial availability. ${ }^{412}$

Sugar was never Puerto Rico's strongest plantation crop. Although introduced in 1736, coffee production finally boomed during the island's economic expansion. Most plantations location in the hinterland were small in size. In total, the plantations produced over 130 million pounds of coffee in 1830. Just twelve years before, the production only equaled 70 million pounds. Europe was Puerto Rico's main importer for its coffee, receiving almost 40 percent by $1881 .^{413}$

Following the end of the second constitutional period, Puerto Rico's population exploded from 261,661 people in 1824 to 447,917 in $1846 .{ }^{414}$ Most free immigrants came from Europe and the West Indies, comprising about 95 percent between 1800 and

${ }^{412}$ Morales Carrión and Teresa Babín, Puerto Rico, 103. Please note this is a very brief look at the plantation economy built during the nineteenth century. Multiple books have analyzed in great depth the cause and effect of Puerto Rico's growth and decline of plantations and cash crops. For further information, please reference Fernando Picó, Libertad y servidumbre en el Puerto Rico del siglo XIX, 1 (Río Piedras: Ediciones Huracan, 1981); Francisco A. Scarano, Sugar and Slavery in Puerto Rico: The Plantation Economy of Ponce, 1800-1850 (Madison: University of Wisconsin Press, 1984); Teresita Martínez-Vergne, Capitalism in Colonial Puerto Rico: Central San Vicente in the Late Nineteenth Century (Gainesville: University of Florida Press, 1992).

${ }^{413}$ Morales Carrión and Teresa Babín, Puerto Rico, 104.

${ }^{414}$ Dietz, Economic History of Puerto Rico, 31. Few studies have been done on the population growth experienced in the Puerto Rico during the nineteenth century. This is partially due to limitation of sources. Some historians have completed specific studies, but a more extensive analysis of Puerto Rico's population boom in the nineteenth century is needed. 
1850. ${ }^{415}$ They originated from places, such as France, the Canary Islands, Costa Firme, Ireland, Scotland, and Spain. ${ }^{416}$ Most immigrants were from all forms of professions, including ship builders, distillers, lawyers, and doctors. ${ }^{417}$ Because of political concerns, free people and slaves were banned entry until the 1840 s to avoid slave rebellions. ${ }^{418}$ It did not stop the flow of slaves being imported to Puerto Rico. In 1828, over 21,721 slaves were imported to multiple ports throughout the island, five times the amount in $1776 .{ }^{419}$

Entrance policies following the Real Cédula de Gracias of 1815 were difficult. Colonial administrators required birth certificates, marriage licenses, sworn statements from the Roman Catholic Church to declare Christian upbringing, documentation and support confirming nationality, and special skills at the very least. Upon arrival, immigrants were to travel to San Juan to swear their allegiance to Spain. All requests required a large sum of money for documentation and travel. ${ }^{420}$ For the immigrants wishing for a new life and abundant land in a conservative, prospering modern colony, the benefits outweighed the expenses. As a result, over 1,674,044 pesos of foreign capital flowed into Puerto Rico for the island's advancement. ${ }^{421}$

\footnotetext{
${ }^{415}$ Chinea, Race and Labor in the Hispanic Caribbean, 73.

${ }^{416}$ Ibid, 76, 77, 112.

${ }^{417}$ Ibid, 92.

${ }^{418}$ Ibid, 71.

${ }^{419}$ Ibid, 108.

${ }^{420}$ Ibid, 69-70.

${ }^{421}$ Ibid, 109 .
} 
Unlike in previous centuries, San Juan was not the main receiver of the new free and enslaved immigrants. Over 90 percent of the West Indies immigrants arrived and settled in the western and southern regions of Puerto Rico, most notable Ponce, Guayama, and Mayaguez. The immigrants followed the prospering plantation economy forming where abundant land was available along the coast and hinterlands. ${ }^{422}$ By 1830 , the capital was no longer the main concentrated center of Puerto Rico despite San Juan's population increasing over the next few decades. The city's population jumped from 3,907 inhabitants in 1816 to over 11,484 residents in 1827 . Unlike the rest of the colony, San Juan's economy never grew at a liner pace during the economic boom and still held its position as the main importing hub. The demographic dynamics would create major issues following the decline of the plantation economy in mid-nineteenth century. ${ }^{423}$

The growing population in the western and southern regions of Puerto Rico quickly flooded the existing infrastructure formed since the island's colonization in the sixteenth century. Unlike San Juan, the remaining island towns still contained similar images of sustainable lifestyles and little advancement as Alejandro O'Reilly and Fryer Agustin Iñigo Abbad y Lasiera had first reported to Spain in the late eighteenth century. ${ }^{424}$ The new arrivals quickly wished for development of the island interior to support plantations and transportation to new expanding ports. The local administration agreed, desiring to make no limitations to the economic boom. Overseeing cabildo

${ }^{422}$ Ibid, 112.

${ }^{423}$ Matos Rodríguez, Women and Urban Change, 20.

${ }^{424}$ Morales Carrión and Teresa Babín, Puerto Rico, 97. 
members advocated that the governor should address the poor conditions of roads, especially in the hinterland. ${ }^{425}$

The results to the pressure became the first advancement in public works. Published records to Spanish colonial government on the status of public works throughout the island occurred yearly beginning in 1828. As public works progressed, costs of supply, workers, and construction were reported to the colonial administration to seek investment back into the island and its economy. These reports also addressed census information by town, census and customs of goods, and increment progress. ${ }^{426}$ The reports between 1828-1830 mainly stressed the growing towns' completion of the Casa del Rey, or administrative office and prison, cemeteries, new churches, and surrounding roads. Bridges were particularly important because of the river systems, which were quicker travel routes for goods to ports. Each town was responsible for interconnecting their transportation system with each other. ${ }^{427}$ Through the colonial administration's interest in developing the island, basic necessities were supplied to the new growing areas in ways never before allowed throughout Puerto Rico's history.

${ }^{425}$ Matos Rodríguez, Women and Urban Change, 25.

426 "Folletos sobre obras públicas, censo y aumento de productos," 4, Ultramar 2015, Archivo Histórico Nacional (Madrid: Portal de Archivo Españoles, 1828-30).

427 "Folletos sobre obras públicas, censo y aumento de productos," 4 Ultramar 2015; "Folletos sobre obras públicas, censo y aumento de productos," 5, Ultramar 2015, Archivo Histórico Nacional (Mardrid: Portal de Archivo Españoles, 1828-30). "Folletos sobre obras públicas, censo y aumento de productos," 6, Ultramar 2015, Archivo Histórico Nacional (Madrid: Portal de Archivo Españoles, 1828-30). 
A focused, stable government, increased revenue, and demographic demands brought public works and sanitation to the forefront of local and colonial administration discussions during Puerto Rico's colonial golden age. Between 1823 and 1850, Puerto Rico's Pax Romana was the prime of public health and infrastructure, stemming from fifty years of changed perceptions to the general population. For economic success, the island's infrastructure needed to be in place. To ensure elite and slave health, sanitation must be enforced and held in high importance. The capital influx paid for the demands until the economic bust brought the golden age to an end.

\section{Building the Modern San Juan: Further Need to Understand Public Work's Role}

When envisioning the future of San Juan, Spanish officials and the growing San Juan elite desired a modern city that resembled other European and American metropolis. Such a city demonstrated the empire and colony's advancements to the world, encouraging financers, international visitors, and new impressions. The elite class and Spanish colonial administrators both feared further political turmoil, especially within the safe-guarded, conservative capital. By building public works and focusing on public health, multiple concerns held by possible dissatisfied residents would not be an issue and divert worries to slave revolts. The idea of "modernizing" held a more social mindset than just basic necessities. The process worked in tandem to remove or relocate "undesired" populations from the capital's walls and established infrastructure and ornamentation to display the colony new found success. ${ }^{428}$

${ }^{428}$ Matos Rodríguez, Women and Urban Change, 3-4. 
As presented in the yearly reports to the Spanish colonial government, San Juan also received improvements like the other new established towns. Conservative ideals and threats brought new focus on modernizing military structures. Throughout the $1830 \mathrm{~s}$, multiple defenses, such as San Cristobal and San Sebastian, received new defenses and walls. The Real Maestranza de Artillería constructed carriages and carts and conducted the repair of arsenal goods. ${ }^{429}$

Analysis of public works and sanitation for San Juan, Puerto Rico, especially in regards to potable water, street infrastructure, and public health have yet to be fully explored in the historiography. Although some historians, such Felix Matos Rodríguez and Teresita Martínez-Vergne, have explained some infrastructure conditions and established beneficencias during the nineteenth century. Matos Rodríguez and MartínezVergne have done so to support their arguments, which in these cases studied the role of women in San Juan in assisting the poor through charity. ${ }^{430}$

The closest general description for a public works program during the midnineteenth century is Adolfo de Hostos' general synthesis. ${ }^{431}$ De Hostos' small excerpts provide an overview of the advances in San Juan's public works. His synthesis does illustrate that water, streets, and public health do not become focal points again in the local and colonial administration until they had become a serious problem. ${ }^{432}$

\footnotetext{
429 "Folletos sobre obras públicas, censo y aumento de productos," 4, Ultramar 2015, 35.

${ }^{430}$ Martínez-Vergne, Shaping the Discourse on Space; Matos Rodríguez, Women and Urban Change.

431 de Hostos, Historia de San Juan, ciudad murada.

432 Ibid.
} 
Potable water became a major crisis in the 1840 s, following ecological changes. With an increase in population, the existing infrastructure and wells could not support the population. Government intervention finally occurred in 1846 when the ayuntamiento organized a commission to divert water to the city. Engineers Juan Manuel Lombera and Carlos Blume developed the plans that would become San Juan's aqueduct. The solution was not immediate, as the aqueduct took until 1871 to complete, following the island economic bust and political upheaval. By its completion, Puerto Rico had changed from its conservative, loyal status to the Spanish crown to an island turning its attention and influence to the United States. ${ }^{433}$

Ecological changes and water concerns correlate to new pathogens exposed to the island and the world. Cholera, a relatively new disease in the nineteenth century, became the new adversary for public health officials. As in other parts of the world, multiple cholera epidemics spread throughout Puerto Rico during the 1830s, 1850s, and 1870s, impacting labor and creating new health concerns for a city wishing to be healthy and modernized. ${ }^{434}$

Lastly, streets and plazas did receive some attention during the height of public works. The actions taken can be viewed as perceived modernization, as the city's expansion was limited to the surrounding military walls finished in the 1770s and the islet. Streets were narrow and unsafe, but vital for communication and transportation. Finally in 1860 , a connecting road outside the military wall was finished to connect

\footnotetext{
${ }^{433}$ Ibid, 479-82.

${ }^{434}$ Ibid, $456-58$.
} 
Barrio Puerto de Tierra and the marina. ${ }^{435}$ However, with the increase of population and focus of social hygiene and conservative worries, administrative attentions diverged from potential preventive measures to consequential actions. ${ }^{436}$

Before making conclusions on the mid-nineteenth century "Pax Romana" attention to public works and health measures, a more extensive study of this time period needs to be conducted. There are available sources and information that do support growth and expansion of public works in San Juan, Puerto Rico beginning in the 1820s. In comparison to the thesis, the mid-nineteenth century brought the San Juan population and administration new obstacles to overcome in order to support the growing population and modernization process. For example, the plantation boom and bust cycles in the late 1840s caused new economic misfortunes. Political strife returned following Governor de la Torre's fifteen year term. Puerto Rico's role in the empire shifted as a new imperial power, the United States, replaced the Spanish monarchy. Political consciousness, economic support, demographic growth, and ecological changes occurred differently in the mid-nineteenth century compared to those of the late eighteenth and early nineteenth centuries.

\footnotetext{
${ }^{435}$ Matos Rodríguez, Women and Urban Change, 15.

${ }^{436}$ de Hostos, Historia de San Juan, ciudad murada, 484-86.
} 


\section{CONCLUSION}

For much of the late eighteenth and early nineteenth centuries, four major factors contributed to potable water and public works concerns in San Juan, Puerto Rico. Public works required a political interest centering on the Puerto Rican infrastructure. A selfsustaining economy provided the financial basis for construction and labor.

Sanitation and infectious disease prevention addressed environmental impacts that altered normal conditions and made the population more susceptible to contagions. Lastly, the population relied on public works to survive, especially in a location that lacked readily available resources, such as water, basic health standards, and transportation. Between 1765 and 1823, dramatic changes and reforms provided the basis that would encourage public works and development in San Juan, Puerto Rico.

Between its colonization in 1508 and 1765, Puerto Rico's positive attributes remained underutilized by its immigrants. Originally settled for its minimal mineral deposits, the island slowly declined after the 1530s as the Spanish monarch's attention turned towards more promising settlements in Costa Firme. Many Hispanic islands found alternative wealth through commercial production, until changes promoted by the monopoly Spanish Fleet System hindered trade. The shift altered Puerto Rico's role within the empire. Colonists became subsistence farmers and utilized the growing contraband trade to fulfill manufactured good needs, while the capital, San Juan, developed into a military outpost to protect trade. Requiring capital to support administrations, troops, and fortifications on an island that produced little of its own, the colonial administration established the situado, an annual subsidy based on New Spain 
funds from mines to supplement local funds. Although beneficial in generating an economy in San Juan, its unpredictable arrival and incomplete amounts caused financial crises throughout the island, particularly the capital. Furthermore, the funds made the island dependent on external sources, never producing enough money to be a sustainable settlement.

Despite economic dependency, political neglect, and a low population, the existing infrastructure established during the capital's early settlement supported its residents. Requiring only minor repairs, the public works and system provided the population with water, some transportation within the area around San Juan, and basic sanitation. Although desiring public works growth, the cabildo was restricted by finances, mainly used to support the stationed military troops and defenses. Focus on the general population remained minimal.

During the last decades of the eighteenth century, Puerto Rico experienced several dramatic changes. Field Marshal Alejandro O'Reilly arrived and transformed the military and its fortifications within San Juan, Puerto Rico. To fulfill his defensive goals, O'Reilly needed to reform Puerto Rico's economy. He attempted to change the economic situado dependency by encouraging agriculture, settlement, and commerce. The population increased at a faster rate than the economy in following decades. As a result, the generated revenue rarely sustained demographic and military needs, thus increasing dependence on New Spain's annual financial shipments. ${ }^{437}$

${ }^{437}$ Ortiz, Eighteenth-Century Reforms in the Caribbean, 188; Morales Carrión and Teresa Babín, Puerto Rico, 52-53. 
Puerto Rico minimally reached Alejandro O’Reilly's economic goal to produce a prospering, rewarding colony for the Spanish crown. Some agricultural development occurred, but still was restricted by the Spanish economic and shipping systems developed under the Bourbon Reforms. Settlement allowed for plantation development, but most immigrants rarely conformed to the demographic group requested. ${ }^{438}$ The economically dependent system continued into the nineteenth century despite knowing its faulty delays and incomplete shipment of money.

Political attention to military and security needs governed the colonial administration throughout the late eighteenth century. The Spanish monarch's Bourbon Reforms prepared the island for future military action. The military and fortifications further relied on the situado to pay for reconstruction and building. ${ }^{439}$ As a result, public works suffered, receiving attention only during ecological crises or special situations. Public works remained at a sustainable level, reflecting earlier centuries. Local governments rarely acted to prevent future damage caused by environmental disasters. These factors contributed to public works' inability to supply the growing need for water, sanitation, transportation and communication between San Juan and the rest of the island.

Prior to 1765, Puerto Rico's established political, economic, demographic, and environmental system supported San Juan's residents with the basic necessities needed for survival. ${ }^{440}$ The late eighteenth-century Bourbon Reform, meant to reorganize Puerto

${ }^{438}$ Chinea, Race and Labor in the Hispanic Caribbean, 48-49, 51.

439 Torres Ramírez, La Isla de Puerto Rico, 230-31.

${ }^{440}$ Matos Rodríguez, Women and Urban Change in San Juan, 14, 90-91; de Hostos, Historia de San Juan, ciudad murada, 477. 
Rico, disrupted and contributed to the established system, altering its ability to handle basic provisions.

Water concerns, public health, and travel restrictions began as political, economic, demographic, and the environment issues slowly destabilized the sustainable, existing public works system. These factors held essential elements that would solve the issue. If political focus changed to public infrastructure and financial funding to could cover the costs, an infrastructure system could be produced that supported a sustainable population and unexpected environmental changes. This sequence would not occur in the late eighteenth century, but the nineteenth-century deconstruction of the established system paved San Juan in this direction.

Britain and Spain's 1797 war directed San Juan on a new course. Britain's attempt to siege San Juan demonstrated that the military reform had been successful. Some historians argue Puerto Rico's future as a self-sufficient, prospering colony began with the siege of 1797 because new colonial attention encouraged growth, but not before early nineteenth-century issues broke the established eighteenth-century system. ${ }^{441}$ The late eighteenth-century developments acted as a catalyst to the growth of public works by disrupting the sustainable system, which had survived for centuries. Nineteenth-century crises altered circumstances to allow public works to become the primary focal point to support the growing San Juan population.

Decentralization and political changes shifted attention to Puerto Rico and its general public. Many officials recognized Puerto Rico's loyalty from their successful

${ }^{441}$ Morales Carrión and Teresa Babín, Puerto Rico, 54-55; Torres Ramírez, La Isla de Puerto Rico, 249-52. 
defense in the 1797 British siege. After King Ferdinand's abdication and the Napoleonic invasion, Puerto Rico pledged allegiance to the governments acting on behalf of the true Spanish Bourbon king, while denouncing the Venezuelan Revolution. After the king's return, Puerto Rico represented a counter-revolutionary haven, while limiting its own liberal movements. ${ }^{442}$

The economic crisis in the first decade of the nineteenth century resulted from centuries-old reliance on the situado system. The situado either never arrived or lacked sufficient funds, causing Puerto Rico to depend on its remaining income. This stressed public works projects, especially when halting all projects to conserve funds. Representative political organizations attempted to improve the economic situation, mainly by introducing paper money. Intendancy reform allowed new changes to the taxation system, abolished financial abuses, and reorganized accounts. ${ }^{443}$

The most influential financial reform came from King Ferdinand VII and his monarchy. The Real Cédula de Gracias of 1815 promoted commerce, agricultural plantation growth, and immigration. Puerto Rico was no longer restricted by Spanish monopolies and traded with other empires under reduced taxes and freedoms. The intendancy removed paper money from circulation and accepted Venezuelan funds, brought by new immigrants, to aid needed metal currency. Under the new reforms and freedoms, Puerto Rico could develop into a self-supporting, flourishing colony. ${ }^{444}$

\footnotetext{
${ }^{442}$ Morales Carrión and Teresa Babín, Puerto Rico, 77-98.

${ }^{443}$ Ibid, 89-98.

${ }^{444}$ Ibid, 89-98.
} 
Spanish revolutions and the Real Cédula de Gracias of 1815 transformed Puerto Rican demography. A new conservative, loyal, skilled population immigrated from other colonies and nations throughout the world. The new demographic group threatened current Puerto Rican Creole liberals, who lost political influence after the Constitution of 1812. This did not mean that they desired a revolution, because the increasing slave and free African population threatened potential slave revolts. Potable water and public works delicately sustained the growing population, but did cause new pressures.

Along with the political upheaval, economic decline, and increasing population, public works primarily advanced through public health and assuring potable water. As the economy declined in the first decade of the nineteenth century, local officials decided to fund public works that were more beneficial to the general population, among which were public health measures, streets, and drinkable water. Unlike the previous century, the military no longer held the majority preference. Representative political governments, particularly during the Constitutional period, promoted street cleaning, medical and hospital advancements, and funding and construction for the poor and less fortunate. Although the administration rarely advanced the infrastructure, it illustrated one of the first times public works captured primary attention.

The returning cabildo under royal absolutism adopted some public works ideas from the previous representative government, but the advancements from the first part of the century had been lost. The discontinued smallpox vaccine introduced in 1804 led to new smallpox epidemics. Despite economic recovery, funds limited public developments 
and still addressed the existing public works system, which had crumbled after decades of use. $^{445}$

Puerto Rico's plantation economy of the mid-1800s allowed for the growth of public works. For the growing economy to survive, the island needed roads and other infrastructure to connect coffee and sugar plantations to exporting ports. The Spanish crown and San Juan's conservative agenda, especially to protect Puerto Rico from revolution, required towns and new growing cities to build administrative buildings and churches. For the first time since its colonization, San Juan was no longer the most populated and expanding urban center on the island. Because it was the capital, San Juan residents wished to develop it into a modern city.

San Juan's public works and sanitation systems developed in the late eighteenth century occurred as stresses on the centuries-old system led to a shift from a military outpost to a potential plantation colony. The early nineteenth century deconstructed the previous system and established a new system based on political interest, economic security, demographic growth, and some environmental control. The established system used the interactions between these factors to form a functioning state that could address basic necessities through public works development. Nevertheless, that same system began producing further pressures and concerns, exposing new weaknesses during the mid-nineteenth century that would ultimately undo the Spanish Empire in the Caribbean.

${ }^{445}$ Rigau-Pérez, "The Introduction of Smallpox Vaccine," 418-20. 


\title{
BIBLIOGRAPHY
}

\author{
Primary Sources
}

“A Leaf from 'A Voyage to Porto Rico'," The Dial: A Magazine for Literature, Philosophy, and Religion. Boston: E. P. Peabody, 1843.

"A Plan of the Island of Porto Rico." Vault: Howe 49. American Memory. Library of Congress. Washington D.C.: Library of Congress, 1760s.

Abbad y Lasiera, Agustin Iñigo. Historia geográfica civil y natural de la isla de San Juan Bautista de Puerto Rico. Río Piedras: Editorial Universitaria Universidad de Puerto Rico, 1979.

Actas del Cabildo de San Juan Bautista de Puerto Rico 1761-1767. San Juan: Publicación Oficial del Gobierno de la Capital, 1954.

Actas del Cabildo de San Juan Bautista de Puerto Rico, 1767-1771. San Juan: Publicación Oficial del Gobierno de la Capital, 1965.

Actas del Cabildo de San Juan Bautista de Puerto Rico, 1774-1777. San Juan: Publicación Oficial del Municipio de San Juan, 1966.

Actas del Cabildo de San Juan Bautista de Puerto Rico, 1774-1777. San Juan: Publicacion Oficial del Municipio de San Juan, 1966.

Actas del Cabildo de San Juan Bautista de Puerto Rico, 1777-1781. San Juan: Publicación Oficial del Municipio de San Juan, 1966.

Actas del Cabildo de San Juan Bautista de Puerto Rico, 1781-1785. San Juan: Publicación Oficial del Municipio de San Juan, 1966.

Actas del Cabildo de San Juan Bautista de Puerto Rico, 1785-1789. San Juan: Publicacion Oficial del Municipio de San Juan, 1966.

Actas del Cabildo de San Juan Bautista de Puerto Rico, 1792-1798. San Juan: Publicación Oficial del Municipio de San Juan, 1967.

Actas del Cabildo de San Juan Bautista de Puerto Rico, 1798-1803. San Juan: Publicación Oficial del Municipio de San Juan, 1968.

Actas del Cabildo de San Juan Bautista de Puerto Rico, 1803-1809. San Juan: Publicación Oficial del Municipio de San Juan, 1970. 
Actas del Cabildo de San Juan Bautista de Puerto Rico, 1809-1810. San Juan: Publicación Oficial del Municipio de San Juan, 1968.

Actas del Cabildo de San Juan Bautista de Puerto Rico, 1810-1812. San Juan: Publicación Oficial del Municipio de San Juan, 1968.

Actas del Cabildo de San Juan Bautista de Puerto Rico, 1812-1814. San Juan: Publicación Oficial de Municipio de San Juan, 1968.

Actas del Cabildo de San Juan Bautista de Puerto Rico, 1815-1817. San Juan: Publicación Oficial del Municipio de San Juan, 1968.

Actas del Cabildo de San Juan Bautista de Puerto Rico, 1817-1819. San Juan: Publicación Oficial del Municipio de San Juan, 1977.

Actas del Cabildo de San Juan Bautista de Puerto Rico, 1820-1821. San Juan: Publicación Oficial del Municipio de San Juan, 1978.

Churruca y Elorza, Cosme Damián de. "Geometrical Plan of the Principal Harbour in the Island of Porto Rico." American Memory. Library of Congress. Washington D.C.: Library of Congress, 1805.

"Circular del obispo don juan alejo de arizmendi sobre la propagación de la vacuna, 1813." Puerto Rico Collection: Pedro de Angelis, Redactor de la Integridad Nacional. Library of Congress, 1813.

"Documentos relativa a la instalación del primer reloj publico que tuvo la capital de Puerto Rico, 1815-1817.” Puerto Rico Collection: Pedro de Angelis, Redactor de la Integridad Nacional. Library of Congress. Washington D. C., 1815-17.

Flinter, George D. An Account of the Present State of the Island of Puerto Rico. London: Longman, Rees, Orme, Brown, Green, and Longman, 1834.

"Folletos sobre obras públicas, censo y aumento de productos." 5, Ultramar 2015. Archivo Histórico Nacional. Mardrid: Portal de Archivo Españoles, 1828-30.

"Folletos sobre obras públicas, censo y aumento de productos." 6, Ultramar 2015. Archivo Histórico Nacional. Madrid: Portal de Archivo Españoles, 1828-30.

"Folletos sobre obras públicas, censo y aumento de productos." 4, Ultramar 2015. Archivo Histórico Nacional. Madrid: Portal de Archivo Españoles, 1828-30. 
Ledru, André Pierre. Viaje a la isla de Puerto Rico en el año 1797, ejecutado por una comisión de sabios franceses, de orden de su gobierno bajo la dirección del Capitán Nicolás Baudín. Río Piedras: Ediciones del Instituto de Literatura Puertorriqueña, 1957.

López de Vargas Machuca, Tomás. "Plano de Puerto Rico." American Memory. Library of Congress. Washington D.C.: Library of Congress, 1785.

Meléndez, Salvador. "Sobre medidas para favorecer la riqueza en Puerto Rico, 1816." 12, Ultramar 1112. Archivo Histórico Nacional. Portal de Archivos Españoles, 1816.

"Negativa al Establecimiento en Puerto Rico de Franceses, 1796," Estado 10. Archivo General de Indias. Portal de Archivos Españoles, 1796.

O'Reilly, Alejandro. "Memoria de D. Alexandro O'Reilly a S. M. sobre la isla de Puerto Rico, en 1765." In Boletín Histórico de Puerto Rico, Cayetano Coll y Toste, ed. San Juan: Academia Puertorriqueña de la Historia, 1972.

"Porto Rico, Wednesday, Storm, Articles, Cuprits." Boston Gazette, 24 September 1787,3 .

Powell, J. H. Bring Out Your Dead: The Great Plague of Yellow Fever in Philadelphia in 1793. Philadelphia: University of Pennsylvania Press, 1949.

Ramírez, Alejandro. "Notificación de daños causados por Huracanes, 1815-1816." 56, Ultramar 1967. Archivo Histórico Nacional. Portal de Archivos Españoles, 181518.

Ramírez, Alejandro and Salvador Meléndez. "Sobre medidas para favorecer la riqueza en Puerto Rico, 1815." 3, Ultramar 1112. Archivo Histórico Nacional. Portal de Archivos Españoles, 1815.

------. "Sobre medidas para favorecer la riqueza en Puerto Rico, 1815." 2, Ultramar 1112. Archivo Histórico Nacional. Portal de Archivos Españoles, 1815.

"Real cédula de S. M. que contiene el reglamento para la población y fomento del comercio, industria y agricultura de la isla de Puerto Rico." Madrid en la Imprenta Real. Library of Congress. Washington D. C., 1815.

"Sobre cantidad a que asciende el situado que sobra la isla, 1811." 2, Ultramar 1072. Archivo Histórico Nacional. Portal de Archivos Españoles, 1811.

Tapia y Rivera, Alejandro. Mis memorias o Puerto Rico como lo encontre y como lo dejo. Barcelona: Ediciones Rumbos, 1968. 
Tomás de Córdova, Pedro. Memorias geográficas, históricas, económicas y estadísticas de la isla de Puerto Rico. Vol. 3. San Juan: Instituto de Cultura Puertorriqueña, 1968.

\section{Secondary Sources}

Aberth, John. The First Horseman: Disease in Human History. Uppder Saddle River: Pearson, 2007.

Alzate Echeverri, Adriana María. Suciedad y orden: reformas sanitarias borboñicas en la Nueva Granada 1760-1810. Bogotá: Editorial Universidad del Rosario, 2007.

Archer, Christon I. "Bourbon Finances and Military Policy in New Spain, 1752-1812." The Americas 37, no. 3 (January 1981).

Brau, Salvador. Historia de Puerto Rico. San Juan: Ediciones, 1971.

------. La colonización de Puerto Rico: desde el descubrimiento de la isla hasta la reversion a la corona española de los privilegios de colón. San Juan: Instituto de Cultura Puertorriqueña, 1969.

------. Puerto Rico y su historia: investigaciones criticas. Valencia: Imprenta de Francisco Vives Mora, 1894.

Bushnell, Amy Turner. Situado and Sabana: Spain's Support System for the Presidio and Mission Provinces of Florida. Athens: University of Georgia Press, 1994.

Campo Lacasa, Cristina. Historia de la iglesia en Puerto Rico (1511-1802). San Juan: Instituto de Cultura Puertorriqueña, 1977.

Camunas Madera, Ricadro R. Epidemias, plagas y marginacion: la lucha contra la adversidad en Puerto Rico en los siglos XVIII y XIX. Puerto Rico: Editorial Universidad de America, 1992.

Caro Costas, Aida R. El juicio de residencia a los gobernadores de Puerto Rico en el siglo XVIII. San Juan: Instituto de Cultura Puertorriqueña, 1978.

Chinea, Jorge L. Race and Labor in the Hispanic Caribbean: The West Indian Immigrant Worker Experience in Puerto Rico, 1800-1850. Gainesville: University Press of Florida, 2005.

------. "Race, Colonial Exploitation and West Indian Immigration in Nineteenth-Century Puerto Rico, 1800-1850." The Americas 52, no. 4 (April 1996): 495-519. 
Cook, Noble David. Born to Die: Disease and New World Conquest, 1492-1620. Cambridge: Cambridge University Press, 1998.

Cook, Noble David and W. George Lovell. "Secret Judgments of God:" Old World Disease in Colonial Spanish America. Norman: University of Oklahoma Press, 1992.

Cubano Iguina, Astrid. Rituals of Violence in Nineteenth-Century Puerto Rico: Individual Conflict, Gender, and the Law. Gainesville: University Press of Florida, 2006.

Curtin, Philip D. Death by Migration: Europe's Encounter with the Tropical World in the Nineteenth Century. Cambridge: Cambridge University Press, 1989.

de Hostos, Adolfo. Crecimiento y desarrollo de la ciudad de San Juan. San Juan: Instituto de Cultura Puertorriqueña, 1957.

-----. Historia de San Juan, ciudad murada: ensayo acerca del proceso de la civilización en la ciudad española de San Juan Bautista de Puerto Rico, 1521-1898. San Juan: Instituto de Cultura Puertorriqueña, 1983.

Dietz, James L. Economic History of Puerto Rico: Institutional Change and Capitalist Development. Princeton: Princeton University Press, 1986.

Dorsey, Joseph C. Slave Traffic in the Age of Abolition: Puerto Rico, West Africa, and the Non-Hispanic Caribbean, 1815-1859. Gainesville: University Press of Florida, 2003.

Fernández Méndez, Eugenio. Crónicas de Puerto Rico: desde la conquista hasta nuestros días, 1493-1955. Barcelona: Editorial Universidad de Puerto Rico, 1973.

-----. Historia Cultura de Puerto Rico, 1493-1968. San Juan: Ediciones "El Cemi," 1970.

------. Histórico de la conquista de Puerto Rico (1508-1640). San Juan: Instituto de Cultura Puertorriqueña, 1970.

-----. Proceso histórico de la conquista de Puerto Rico (1508-1640). San Juan: Instituto de Cultura Puertorriqueña, 1970.

Figueroa, Luis A. Sugar, Slavery, and Freedom in Nineteenth-Century Puerto Rico. Chapel Hill: University of North Carolina Press, 2005.

Gill, Richardson Benedict. The Great Maya Droughts: Water, Life, and Death. Albuquerque: University of New Mexico, 2000. 
Gómez de Cruz, Magda. "Smallpox Vaccination, the Establishment of Vaccination Boards, and State Formation in Venezuela and Cuba in the Nineteenth Century." Miami: Florida International University, 2008.

Johnson, Sherry. "El Niño, Environmental Crisis, and the Emergence of Alternative Markets in the Hispanic Caribbean, 1760s-70s." William and Mary Quarterly 62, no. 3 (July 2005).

------. "La Guerra Contra los Habitantes de los Arrabales: Changing Patterns of Land Use Tenancy in and Around Havana, 1763-1800."

------. The Social Transformation of Eighteenth-Century Cuba. Gainesville: University of Florida Press, 2001.

Kinsbruner, Jay. "Caste and Capitalism in the Caribbean: Residential Patterns and House Ownership Among the Free People of Color of San Juan, Puerto Rico, 18231846." Hispanic American Historical Review 70, no. 3 (August 1990): 433-61.

------. "The Pulperos of Caracas and San Juan During the First Half of the Nineteenth Century." Latin American Research Review 13, no. 1 (1978): 65-85.

------. The Colonial Spanish-American City: Urban Life in the Age of Atlantic Capitalism. Austin: University of Texas Press, 2005.

Kiple, Kenneth F. "Cholera and Race in the Caribbean." Journal of Latin American Studies 17, no. 1 (May 1985): 157-77.

Koeppel, Gerard. Water for Gotham: A History. Princeton: Princeton University Press, 2000.

López Cantos, Angel. Historia de Puerto Rico, 1650-1700. Seville: De Estudios Hispano-Americanos, Consejo Superior de Investigaciones Científicas, 1975.

Lynch, John. The Spanish-American Revolutions, 1808-1826. New York: W. W. Norton, 1973.

Martínez-Vergne, Teresita. Capitalism in Colonial Puerto Rico: Central San Vicente in the Late Nineteenth Century. Gainesville: University of Florida Press, 1992.

------. Shaping the Discourse on Space: Charity and Its Wards in Nineteeth-Century San Juan, Puerto Rico. Austin: University of Texas Press, 1999.

Matos Rodríguez, Félix V. Women and Urban Change in San Juan, Puerto Rico, 1820 1868. Gainesville: University Press of Florida, 1999. 
Mayo Santana, Raúl and Mariano Negrón-Portillo. La esclavitud urbana en San Juan de Puerto Rico. San Juan: Ediciones Huracán, 1992.

McNeil, William H. Plagues and People. New York: Anchor Book, 1976.

Morales Carrión, Arturo. Auge y decadencia de la trata negrera en Puerto Rico (18201860). San Juan: Instituto de Cultura Puertorriqueña, 1978.

------. Puerto Rico and the Non-Hispanic Caribbean: A Study in the Decline of Spanish Exclusivism. Río Piedras: University of Puerto Rico Press, 1952.

Morales Carrión, Arturo and María Teresa Babín. Puerto Rico: A Political and Cultural History. New York: W.W. Norton, 1983.

Mulcahy, Matthew. Hurricanes and Society in the British Greater Caribbean, 16241783. Baltimore: John Hopkins University Press, 2006.

Ortiz, Altgracia. Eighteenth-Century Reforms in the Caribbean: Miguel de Muesas, Governor of Puerto Rico 1769-1776. Rutherford, Madison, Teaneck: Fairleigh Dickinson University Press, 1983.

Pérez, Louis A. Winds of Change: Hurricanes and the Transformation of Nineteenth Century Cuba. Chapel Hill: University of North Carolina Press, 2001.

Picó, Fernando. Libertad y servidumbre en el Puerto Rico del siglo XIX. 1. Río Piedras: Ediciones Huracan, 1981.

Rigau-Pérez, José G. "The Introduction of Smallpox Vaccine in 1803 and the Adoption of Immunization as a Government Function in Puerto Rico." Hispanic American Historical Review 69, no. 3 (August 1989).

------. "Surgery at the Service of Theology: Postmortem Cesarean Section in Puerto Rico and the Royal Cedula of 1804." Hispanic American Historical Review 75, no. 3 (August 1995): 377-404.

Rosario Rivera, Raquel. La real cédula de gracias de 1815 y sus primeros efectos en Puerto Rico. San Juan, 1995.

Scarano, Francisco Antonio. Immigración y clases sociales. 1. Río Piedras: Ediciones Huracan, 1981.

------. Sugar and Slavery in Puerto Rico: The Plantation Economy on Ponce, 18001850. Madison: University of Wisconsin Press, 1984. 
-----. "The Jibaro Masquerade and the Subaltern Politics of Creole Identity Formation in Puerto Rico, 1745-1823." American Historical Review 101, no. 5 (December 1996).

Schwartz, Stuart B. "The Hurricane of San Ciriaco: Disaster, Politics, and Society in Puerto Rico, 1899-1901." Hispanic American Historical Review 72, no. 3 (August 1992): 303-34.

Stahl, D. Agustín. Los indios borinqueños. Ann Arbor: University Micofilms International, 1980.

Stark, David Martin. "Family Life of Slaves in Puerto Rico: Demographic Evidence from the Years, 1675-1800." Ann Arbor: UMI Dissertation Services, 1999.

------ "Rescued from Their Invisibility: The Afro-Puerto Ricans of Seventeenth-and Eighteenth- Century San Mateo de Cangrejos, Puerto Rico." The Americas 63, no. 4 (April 2007): 551-86.

-----. "“There is no City Here, but a Desert': The Contours of City Life in 1673 San Juan.” Journal of Caribbean History 42, no. 2 (2008): 255-89.

Szásadi, Adam. "Credit-Without Banking-In Early Nineteenth-Century Puerto Rico.” The Americas 19, no. 2 (October 1962): 149-71.

-----. "La municipalidad de San German en Puerto Rico (1798-1808)." Journal of InterAmerican Studies 1, no. 4 (October 1959): 489-513.

Tannenbaum, Rebecca J. The Healer's Calling: Women and Medicine in Early New England. Ithaca: Cornell University Press, 2002.

Torres Ramírez, Bibiano. Alejandro O'Reilly en las Indies. Seville: Escuela de Estudios Hispano-Americanos, 1969.

-----. La Isla de Puerto Rico (1765-1800). San Juan: Instituto de Cultura Puertorriqueña, 1968. 


\section{APPENDICES}

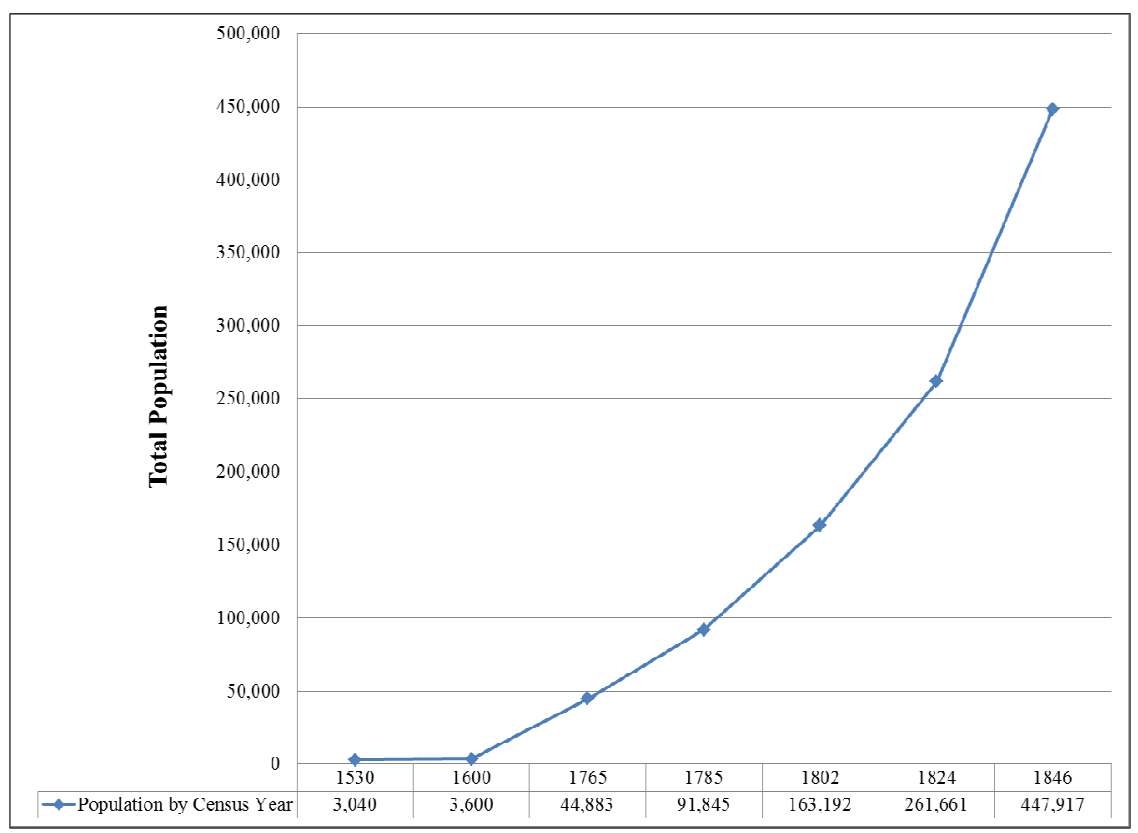

Table 1: Total Population of Puerto Rico by Select Census Years, 1530-1846. Population is based on available recorded censuses.

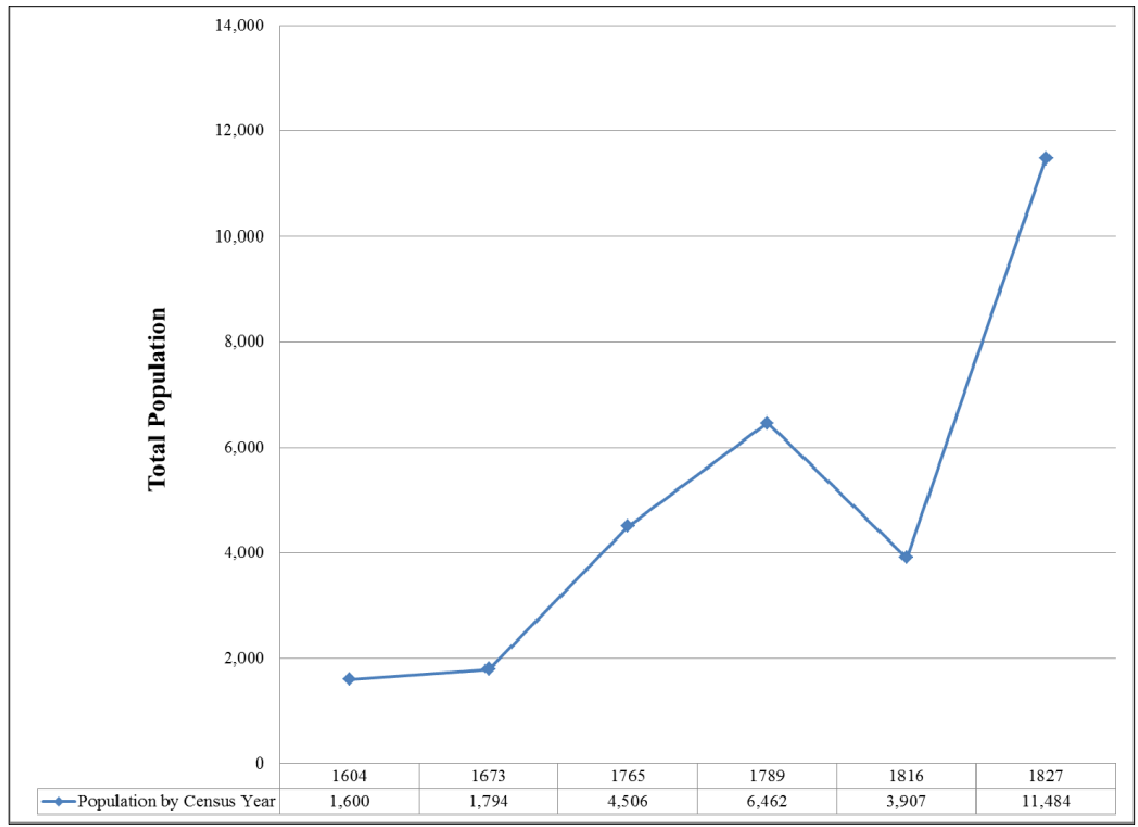

Table 2: Total Population of San Juan, Puerto Rico, by Select Census Year, 1604-1827. Population is based on available recorded censuses. 


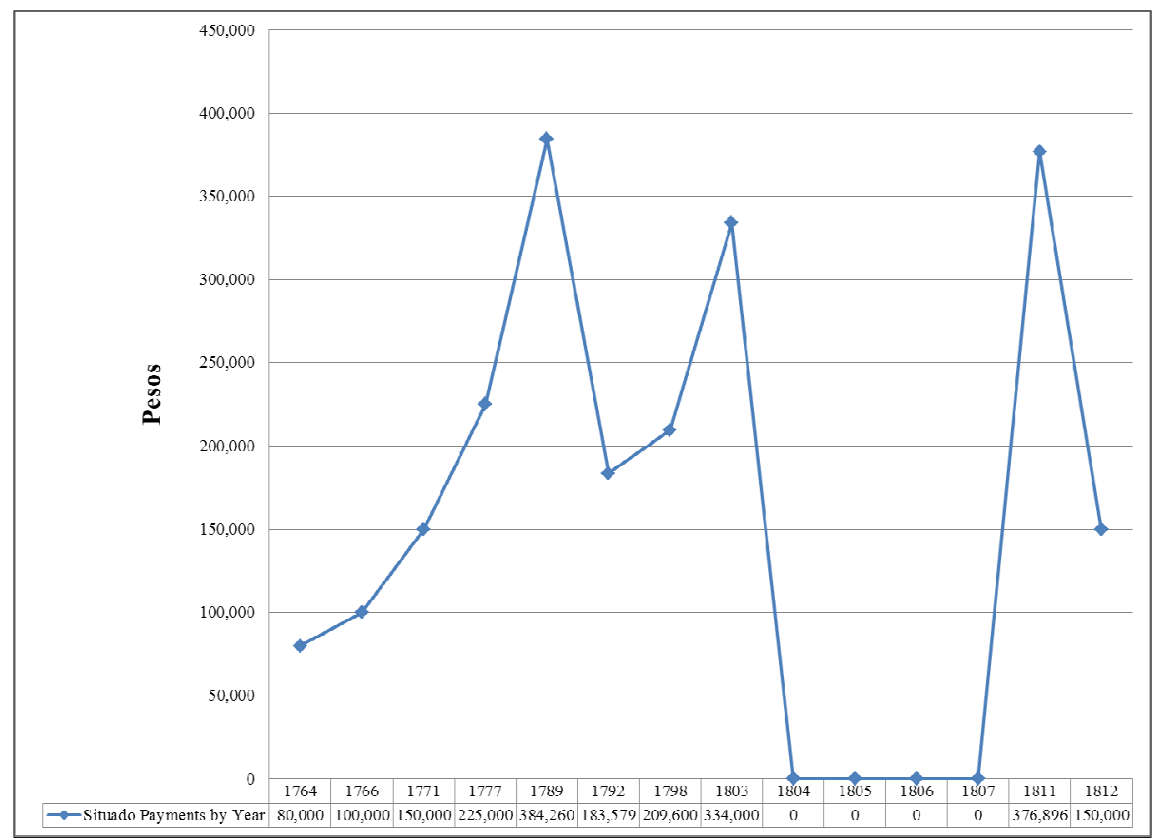

Table 3: Situado Shipments to Puerto Rico by Year, 1764-1812. The shipment totals are based on available data from primary and secondary sources. 